\author{
UNIVERSIDADE DE SÃO PAULO \\ ESCOLA DE ARTES, CIÊNCIAS E HUMANIDADES \\ PROGRAMA DE PÓS-GRADUAÇÃO EM SUSTENTABILIDADE
}

FELIPE DOS REIS CAMPOS

Controvérsia, política e risco: enquadrando os transgênicos nos portais Estadão Digital e Folha de S. Paulo 

FELIPE DOS REIS CAMPOS

\title{
Controvérsia, política e risco: enquadrando os transgênicos nos portais Estadão Digital e Folha de S. Paulo
}

\author{
VERSÃO ORIGINAL
}

Dissertação apresentada à Escola de Artes, Ciências e Humanidades da Universidade de São Paulo para obtenção do título de Mestre em Ciências pelo programa de Pós-graduação em Sustentabilidade.

Área de concentração: Gestão Ambiental

Orientador: Cristiano Luis Lenzi 
Autorizo a reprodução e divulgação total ou parcial deste trabalho por qualquer meio convencional ou eletrônico, para fins de estudo e pesquisa, desde que citada a fonte

CATALOGAÇÃO-NA-PUBLICAÇÃO

(Universidade de São Paulo. Escola de Artes, Ciências e Humanidades. Biblioteca)

Campos, Felipe dos Reis

Controvérsia, política e risco :

enquadrando os transgênicos nos portais

Estadão Digital e Folha de S. Paulo / Felipe

dos Reis Campos ; orientador, Cristiano Luis

Lenzi. - 2017

$100 \mathrm{p}$.

Dissertação (Mestrado em Ciências)

- Programa de Pós-Graduação em

Sustentabilidade, Escola de Artes,

Ciências e Humanidades, Universidade

de São Paulo

Versão original

1. Risco ambiental. 2. Alimentos

transgênicos. 3. Mídia. I. Lenzi,

Cristiano Luis, orient. II. Título

CDD 22.ed. - 363.7 
Dissertação submetida à Banca de Defesa de Mestrado de autoria de Felipe dos Reis Campos, sob o título "Controvérsia, política e risco: enquadrando os transgênicos nos portais Estadão Digital e Folha de S. Paulo", apresentada à Escola de Artes, Ciências e Humanidades da Universidade de São Paulo, como parte dos requisitos para obtenção do título de Mestre em Ciências pelo Programa de Pós-graduação em Sustentabilidade, na área de concentração Gestão Ambiental, aprovada em de de 2017 pela banca examinadora constituída por:

Prof. (a). Dr. (a).

Instituição:

Presidente:

Prof. (a). Dr. (a).

Instituição:

Aprovado [ ]

Reprovado [ ] Ass.:

Prof. (a). Dr. (a).

Instituição:

Aprovado [ ]

Reprovado [ ] Ass.:

Prof. (a). Dr. (a).

Instituição:

Aprovado [ ]

Reprovado [ ] Ass.: 


\section{Agradecimentos}

Problemas ambientais não batem à porta de nossa casa dizendo como devemos tratá-los. Se apresentam a nós como são em si mesmos, muito além de nosso desejo de enquadrá-los em categorias do conhecimento já estabelecidos. Por isso só posso agradecer aqueles que, das mais distintas áreas do saber, me proporcionaram os instantes mais alegres da minha vida:

À Universidade de São Paulo, à Coordenação de Aperfeiçoamento de Pessoal de Nível Superior e a minha família pelo apoio estrutural e financeiro

Aos docentes e amigos de pós em Sustentabilidade (EACH/USP), Administração (FEA/USP), Linguística (IEL/UNICAMP), Análise Crítica do Discurso (FFLCH/USP), Ciências da Comunicação (ECA/USP) e Ambiente e Sociedade (NEPAM/IFCH/UNICAMP)

Aos docentes Alexandre Igari, Eduardo Viglio, Fábio Bacchiegga e Sylmara Dias por aceitarem o convite para a suplência de defesa do projeto

Às docentes Gabriela Di Giulio, Graça Caldas e Laura Martirani por aceitarem o convite para a banca de defesa do projeto

Aos docentes Danilo Rothberg e Laura Alves Martirani pelas valiosas contribuições no exame de qualificação do projeto

Aos docentes Lúcia Ferreira, Helene Ueno, Sérgio Pacca, Sylmara Dias e Waldir Mantovani, essenciais para minha formação

Aos amigos Alexander Bakri, André Gomes, Daniel Baldio, Érico Pagotto, Igor Carnário, Iran Augustus, Jomar Pavanetti, Kyene Becker, Rodrigo Saffin, Samir Barbieri, Susan Okuno e Thomas Benton que me ajudaram ou motivaram de alguma forma

Em especial ao professor Cristiano pela orientação e amizade nesses últimos anos 


\section{Resumo}

CAMPOS, Felipe dos Reis. "Controvérsia, política e risco: enquadrando os transgênicos nos portais Estadão Digital e Folha de S. Paulo". 2017. 100 p. Dissertação (Mestrado em Sustentabilidade) - Escola de Artes, Ciências e Humanidades, da Universidade de São Paulo, São Paulo, 2017. Versão Original.

Frames são dispositivos cognitivos que organizam os sentidos da vida cotidiana. Enquadrar um risco ambiental é fazer mais saliente algumas de suas possibilidades, promovendo uma ou outra interpretação. A dissertação examina como a pauta dos transgênicos tem sido enquadrada pelos portais Estadão Digital <estadao.com.br> e Folha de S. Paulo < folha.uol.com.br> no período de 1998 a 2015. Para tanto, mediante a análise dos elementos textuais dos artigos (metáforas, escolhas de palavras e argumentos), 1.396 notícias foram classificadas em um dos seguintes frames de notícia: progresso, prospecto econômico, ética, caixa de Pandora, descontrole, natureza, responsabilidade pública e globalização. Os achados revelam que o frame predominante foi "responsabilidade pública", especialmente durante o biênio 2003/04 que antecedeu a sanção da "Lei da Biossegurança" em 2005. Mas antes de comunicar informações plurais, equilibradas, relacionando antecedentes e pressupostos, avaliando implicações e examinando alternativas e critérios de comparação, a mídia paulista tratou muito mais dos aspectos associados às polêmicas e conflitos políticos nacionais.

Palavras-chave: Transgênicos. Risco ambiental. Mídia. Enquadramentos. Análise de frame. 


\begin{abstract}
CAMPOS, Felipe dos Reis. Controversy, politics and risk: framing the transgenics agenda in S. Paulo State's Press (Estadão Digital and Folha de S. Paulo). 2017. 100 p. Dissertation (Master in Sustainability) - School of Arts, Science and Humanities, University of São Paulo, São Paulo, 2017. Original version.

Frames are cognitive devices that organizes the meanings of everyday life. To frame a certain environmental risk is to do more prominent some of its possibilities which promote one or another interpretation. The research examines how the agenda of transgenic organisms has been framed by the Brazilian online newspapers Estadão Digital <estadao.com.br> and Folha de S. Paulo <folha.uol.com.br> from 1998 to 2015. To do so, an analysis of the internal textual elements (metaphors, selection of words and arguments) presented in the articles was done, resulting in 1.396 classified news according to one of the following news frames: progress, economic prospect, ethics, Pandora's box, runaway technology, nature/nurture, public accountability and globalization. The findings suggest that "public accountability" was the most frequently identified frame, especially during the years 2003/04, which preceded the sanction of the "Biosafety Law", in March 2005. Thus, despite communicating plural and balanced information, relating antecedent and assumptions, evaluating and examining alternatives and comparison criteria, the state of São Paulo's press has been dealing much more with the controversies and political conflict aspects of the subject.
\end{abstract}

Key-words: GMO. Environmental risk. Mass media. Framing. Frame analysis. 


\section{LISTA DE TERMOS TRADUZIDOS}

Análise de frame

Caixa de Pandora

Descontrole

Enquadramento (processo)

Ética

Editor (define o que será noticiado)

Enquadramento

Frames de notícia

Globalização

Quadro

Natureza

Progresso

Produção de notícia

Prospecto Econômico

Responsabilidade Pública

Sementes de uma geração
Frame analysis

Pandora's box

Runaway technology

Framing

Ethics

Gatekeeper

Framing

News frames

Globalization

Frame

Nature/nurture

Progress

Newsmaking

Economic prospect

Public accountability

Terminator 


\section{LISTA DE ABREVIATURAS E SIGLAS}

$\mathrm{AF}$

Anbio

CNTBio

CADE

EMBRAPA

ESPD

ETI

EUA

FSP

IDEC

INPI

MST

MP

MPF

OGM

ONG

$\mathrm{ONU}$

PF

PL

$\mathrm{RR}$

TRF

UE

Análise de Frame

Associação Nacional de Biossegurança

Comissão Técnica Nacional de Biossegurança

Conselho Administrativo de Defesa Econômica

Empresa Brasileira de Pesquisa Agropecuária

Estadão Digital

Elementos Textuais

Estados Unidos da América

Folha de S. Paulo

Instituto de Defesa do Consumidor

Instituto Nacional Propriedade Industrial

Movimentos dos Trabalhadores Rurais Sem Terra

Medida Provisória

Ministério Público Federal

Organismo Geneticamente Modificado

Organização não governamental

Organização das Nações Unidas

Polícia Federal

Projeto de lei

Roundup Ready

Tribunal Regional Federal

União Europeia 


\section{SUMÁRIO}

INTRODUÇÃ

1.1 JUSTIFICATIVA E RELEVÂNCIA SOCIAL ....................................... 16

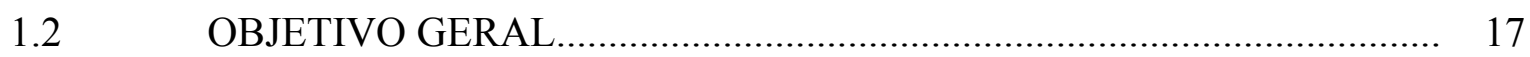

OBJETIVOS ESPECÍFICOS ......................................................... 17

PROCEDIMENTOS METODOLÓGICOS.............................................. 18

$2.1 \quad$ ESCOLHA POR FRAMES CULTURAIS............................................ 18

2.2 ANÁLISE DE CONTEÚDO POR CATEGORIAS.................................. 18

2.3 TIPOLOGIA DE FRAMES.............................................................. 19

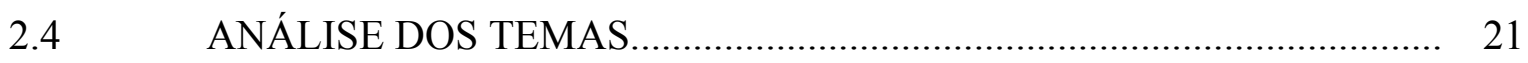

$2.5 \quad$ ANÁLISE DAS ONDAS DE EVENTOS.............................................. 21

2.6 GÊNESE DO CORPUS E AMOSTRAGEM......................................... 22

3 MÍDIA, FRAMES E PROBLEMAS AMBIENTAIS............................ 26

3.1 CONSTRUÇÃO DE PROBLEMAS SOCIOAMBIENTAIS...................... 26

3.2 NEWSMAKING E A CONSTRUÇÃO SOCIAL DE REALIDADES....... 32

3.3 ORGANIZAÇÃO DA EXPERIÊNCIA EM FRAMES DE NOTÍCIA....... 35

INDEFINIÇÃO DE UM CONCEITO...................................................... 37

3.5 VALIDADE E CONFIABILIDADE PARA FRAMES............................. 38

3.6 PROPOSIÇÃO DE UM MODELO PARA FRAMES................................ 42

4 MÍDIA, RISCO E TRANSGÊNICOS.................................................. 44

4.1 BREVE COMENTÁRIO À SOCIEDADE DE RISCO............................. 44

4.2 A CONSTRUÇÃO SOCIAL DO RISCO................................................ 45

O RISCO SEGUNDO A MÍDIA............................................................ 48

4.4 TRANSGÊNICOS COMO UMA PAUTA MIDIÁTICA........................... 51

4.5 PESQUISAS EMPÍRICAS QUE EMPREGARAM A TIPOLOGIA.......... 55

4.6 TRANSGÊNICOS NA IMPRENSA BRASILEIRA................................ 58

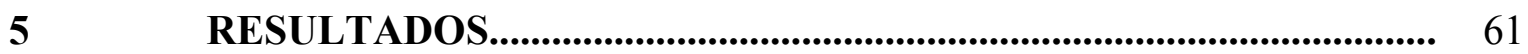

5.1 CARACTERÍSITCAS DA AMOSTRA................................................. 61

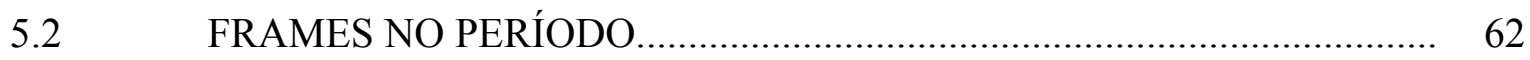

5.3 DIFERENÇAS ENTRE JORNAIS....................................................... 63

5.4 SUPREMACIA E QUEDA DE “RESPONSABILIDADE PÚBLICA”...... 65

5.5 QUEDA EM “GLOBALIZAÇÃO....................................................... 66

5.6 INSTABILIDADE EM “CAIXA DE PANDORA”.................................. 68 
5.7 AVANÇO DE “PROGRESSO”........................................................... 70

5.8 ONDAS QUE CENTRALIZARAM O DEBATE.................................... 71

5.8.1 Introdução comercial: 1998/2002 ........................................................... 72

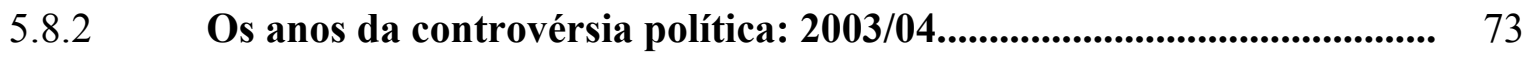

5.8.3 Controvérsias para além da regulação: 2005/15..................................... 78

$6 \quad$ CONSIDERAÇÕES FINAIS..................................................................... 82

REFERÊNCIAS BIBLIOGRÁFICAS

ANEXO A - EXEMPLOS DE CLASSIFICAÇÃO

ANEXO B - TIPOLOGIA DE FRAMES POR AUTOR

ANEXO C - ESTATÍSTICAS GERAIS

ANEDO D - AMOSTRAGEM 


\section{INTRODUÇÃO}

A agricultura tem sido um dos principais fatores para o progresso das civilizações ocidentais nos últimos doze mil anos. No século passado, a humanidade vivenciou um "boom" na produção de alimentos, reduzindo drasticamente a fome em um planeta que dobrou sua população. Apesar disso, painéis apresentados na Rio+20 e em outras cúpulas para o ambiente calculam que a cada sete pessoas uma continua sem acesso a quantidades recomendadas de energia. Os mesmos painéis apontam para os desafios de nutrir a estimativa de nove bilhões de pessoas nas próximas décadas. Nesse cenário, não é raro quem discurse que o desenvolvimento econômico se sustentará na racionalidade científica e a humanidade será capaz de superar quaisquer adversidades pela produtividade. Os transgênicos, como um produto do avanço tecnológico, não seriam somente uma alternativa desejável, mas inevitável.

Entretanto, o consenso para os organismos do tipo está longe de ser unânime (LENZI, 2012; LENZI, 2013). Nos últimos anos, os transgênicos têm sido palco de controvérsias devido a um conjunto de incertezas sociais e técnicas envoltas à sua produção, comercialização e consumo. Em uma combinação de situações concretas e hipotéticas, e.g., a aparição da doença "vaca louca", riscos para câncer, a morte de espécies de insetos, desequilíbrios em ecossistemas, maior uso de agrotóxicos, dominação de sementes por royalties e até mesmo o monopólio da vida por um pequeno clube de corporações capitalistas, presencia-se um contraste com a nova era de progresso anunciada pela biotecnologia agrícola.

Diante de tantas incertezas, diversos atores interessados na questão (cientistas, políticos, oficiais do governo, ambientalistas, etc.) passam a agir para que seus quadros de interpretação a respeito de riscos e benefícios sejam aceitos como verdade. Assim, a grande mídia (jornais, televisão, rádio e portais de internet) se caracteriza como arena crucial para a legitimação desses quadros. Em primeiro, porque a mídia representa o principal canal de informação a maior parte da população. Em segundo, ela dá credibilidade aos pontos de vista, especialmente quando é cada vez mais comum a disseminação de notícias falsas. Em terceiro, pois ela agenda as questões mais discutidas em sociedade, que dão o substrato para conversas informais entre indivíduos e à formação da opinião pública. Por último, aquilo que não está nas notícias de jornal, de certa forma, não possui uma existência social (HANNIGAN, 2006: 77).

Mas decidir o que dos transgênicos vira notícia não é tarefa simples - as dificuldades enfrentadas por jornalistas começam pela complexidade da pauta, que envolve jargões técnicos, 
ciência, ética, política, economia, direito de informação e, sobretudo, quadros interpretativos de riscos que vão ao encontro de um ou outro interesse. Assim, é preciso escolher quais aspectos dos transgênicos se tornarão manchetes, que por sua vez, promovem certos enquadramentos. Frames, ou quadros, são dispositivos culturais de se organizar ideias em categorias maiores que privilegiaria certos aspectos em detrimentos de outros (ENTMAN, 1993; GITLIN, 1980; MILLER \& RIECHERT, 2000). O sociólogo Ervin Goffman ([1974] 1986: 21), creditado pela introdução do conceito, define frames como "princípios de organização que determinam os eventos e nosso envolvimento com eles". Nos últimos anos, a análise de frames tem sido reconhecida como um poderoso método orientado para a compreensão de questões sobre mídia e política, atentando-se para a disputa entre atores nas constituições de quadros, além de seus efeitos na opinião pública e em mobilizações coletivas.

Sob essa metodologia, uma série de estudos empíricos em diversos países tem buscado revelar quais frames de notícia para transgênicos e biotecnologia têm sido dominantes em diferentes períodos. Nas imprensas europeias e norte-americana, pesquisas indicam que por duas décadas, desde os anos 1970, os transgênicos foram enquadrados como um produto que traria uma era de "progresso", erradicaria a fome e seriam mais produtivos (BAUER, 2001; DURANT et al., 1998; NISBET \& LEWENSTEIN, 2002). Contudo, no decorrer dos anos 1990, momento em que há maior interesse pela causa ambiental, a concepção do primeiro clone animal, o mal da vaca louca, a morte de borboletas e algumas pesquisas publicadas em revistas de prestígio sobre a associação com tipos de câncer, observa-se um maior enquadramento para “ética" e "caixa de Pandora" e principalmente "responsabilidade pública", como resposta de muitos governos a uma reformulação da regulação.

Nos portais de notícia de São Paulo os padrões de enquadramento foram ligeiramente diferentes. Somente ao final de 1998 que os transgênicos se estabeleceram como pauta recorrente na agenda da mídia. Não por influência direta dos eventos concretos ou hipotéticos de risco reportados na União Europeia e Estados Unidos, mas por acontecimentos internos e relativos ao posicionamento estratégico do país como um agroexportador, ao desenvolvimento nacional e, sobretudo, aos confrontos políticos envoltos à regulação. De um lado desses conflitos, era comum a atuação de grandes produtores, políticos orientados ao desenvolvimento e representantes da agroindústria favoráveis aos transgênicos. De outro, organizações não governamentais, órgãos oficiais de defesa do consumidor, ambientalistas, movimentos sociais e alguns partidos que buscavam barrar seu plantio. 
Em linhas gerais, no decorrer dos primeiros anos da introdução comercial da soja $R R$ (1998/2002), foram a falta de lei específica e as judicializações da matéria que centralizaram a cobertura midiática. Se por um lado não havia proibição clara, por outro levantava-se a ausência de estudos que resguardassem o princípio constitucional de precaução. No entanto, o ápice do noticiamento ocorreu no biênio 2003/04, período de acentuado conflito político que precedeu à sanção da "Lei da Biossegurança" (11.105/2005). Esse ínterim se caracterizou pelas discussões sobre uma legislação definitiva que estabelecesse normas de segurança e mecanismos de fiscalização sobre a produção e comercialização de transgênicos.

Nos últimos anos da análise, a quantidade de notícias declina consideravelmente, mas nem por isso a narrativização dos conflitos políticos e controvérsias entre atores deixam de ser o principal critério de noticiabilidade empregado pelos portais. Por exemplo, mesmo após uma década da sanção e discussão da "Lei da Biossegurança", em 2015 houve forte mobilização política disposta a decretar o fím dos símbolos indicativo de transgênicos em rótulos. Não somente nos artigos de Ciência, Mercado, Economia e Política (nos quais a pauta é tradicionalmente veiculada) mas também na seção de Opinião, um conjunto de atores políticos se enfrentava outra vez.

Destaca-se em todos esses anos nos portais Estadão Digital e Folha de S. Paulo, independente do acontecimento noticiado, a tendência para o noticiamento de conflitos políticas e polêmicas. À vista disso, o objetivo dessa dissertação foi identificar e analisar os frames de notícia em dois portais influentes de São Paulo de 1998 a 2015.

Essa pesquisa se contextualiza dentro de uma discussão iniciada em diversos estudos midiáticos para a biotecnologia e biotecnologia agrícola que empregaram uma mesma tipologia de frames em diversas nações. Durant et al. (1998) organizaram a publicação "Biotechnology in the public sphere: A European source book", uma compilação de estudos em imprensas europeias no intervalo de 1973 a 1994. Bauer et al. (2001), continuaram a análise de jornais europeus de 1992 a 1999. Em 2002, Dahinden observa em detalhes a mídia suíça desde os anos 1980, ao passo que Nisbet e Lewenstein verificam a norte americana, que volta a ser analisada por Reinhart em 2007. Ainda nesse ano, Bonfadelli et al. volta a mídia suíça, enquanto na Bélgica, Maeseele investiga o período de 2000/04. Por fim, Gastrow (2010) tem a África do Sul como objeto, tendo seu recorte temporal de 2005 a 2010.

Em síntese, as pesquisas de Durant et al. (1998), Dahinden (2002) e Nisbet e Lewenstein (2002) apontam que a biotecnologia e biotecnologia agrícola foram enquadradas por via de regra em "progresso" por duas décadas a partir dos anos 1970. No entanto, durante os anos 
1990, vários eventos de risco colocaram em cheque a segurança da biotecnologia. Observa-se tão logo um maior enquadramento para "Caixa de Pandora", "ética", e principalmente “responsabilidade pública”, padrão que persiste até meados dos anos 2000 nos estudos de Reinhart (2007), Bonfadelli et al. (2007) e Maeseele (2007). Na contramão de seus pares, os dados de Gastrow (2010) sinalizam um declínio em "responsabilidade pública" a partir de meados de 2000, ao mesmo tempo em que "progresso" aumenta significativamente.

\subsection{JUSTIFICATIVA E RELEVÂNCIA SOCIAL}

Frames de notícia são capazes de fornecer as bases interpretativas para que a audiência leiga forme sua opinião a respeito de uma questão tão complexa e impactante na vida cotidiana (BAUER, 2002; REINHART, 2007). Espera-se que essa pesquisa permita com que os portais paulistas reflitam sobre a atuação de seu enquadramento. Que os jornalistas busquem contemplar informações mais esclarecedoras, plurais, equilibradas, que relacionem antecedentes e pressupostos, avaliando implicações e propondo alternativas e outros critérios de comparação. Talvez assim, a sociedade possa melhor deliberar sob quais circunstâncias a biotecnologia agrícola deve e pode ser adotada.

Antes de constituírem-se como uma reflexão técnica, frames de transgênicos são objetos de disputa simbólica fundados na moralidade, cuja atenção da audiência leiga volta-se menos para a robustez das evidências científicas e iminência do perigo acontecer, mas mais às vozes que se destacam na avaliação das informações de riscos e benefícios. No Brasil, onde os interesses do agronegócio são bem representados nas esferas do poder público, ao mesmo tempo que diversos grupos da sociedade civil alertam para as ameaças da biotecnologia agrícola, uma pesquisa que diagnóstica os vários quadros de transgênicos pode lançar luz sobre o modo como os organismos do tipo têm sido estruturados no debate público.

Por último, quando agendados na mídia, problemas ambientais que envolvem muita linguagem técnica tendem a causar confusão, dúvidas e ignorância para leigos (BROSSARD \& SHANAHAN, 2007; RYAN, 2014; STOCKING \& HOLSTEIN, 2009). Por essa razão, uma pesquisa que busca um melhor esclarecimento de como os transgênicos têm sido debatidos poderia sinalizar uma atuação mais plural da mídia que integrasse distintos saberes em busca de soluções coletivas para os riscos associados aos transgênicos. 


\subsection{OBJETIVO GERAL}

Identificar e analisar os frames de notícia para os transgênicos nos portais Estadão Digital e Folha de S. Paulo no período de 1998 a 2015.

\subsection{OBJETIVOS ESPECÍFICOS}

Selecionar as notícias que abordaram a pauta dos transgênicos;

Identificar nas notícias a presença dos seguintes elementos textuais:

1. Metáforas;

2. Escolhas de palavras;

3. Argumentos.

A seguir, classificá-las em um dos seguintes frames: progresso, prospecto econômico, ética, caixa de Pandora, descontrole, natureza, responsabilidade pública e globalização;

Analisar os padrões das séries históricas de frames;

Identificar os principais temas pautados;

Identificar os principais conjuntos de episódios (ondas) que centralizaram o debate. 


\section{PROCEDIMENTOS METODOLÓGICOS}

\subsection{ESCOLHA POR FRAMES CULTURAIS}

Escolhemos examinar os frames nos portais Estadão Digital e Folha de S. Paulo pela sua definição de viés cultural, considerando-os como socialmente construídos, facilmente identificáveis, duradouros e que transcendem a fatos circunstanciais. Optamos pela tipologia de Durant et al. (1998) adaptada de Gamson e Modigliani (1989) ${ }^{1}$, por ser amplamente utilizada para a biotecnologia e pela sua capacidade de avaliar longos períodos.

\subsection{ANÁLISE DE CONTEÚDO POR CATEGORIAS}

Uma vez que a análise de frame não pode ser considerada como uma técnica de análise, é comum o emprego da análise de conteúdo. Procuramos identificar a presença de elementos textuais (metáforas, argumentos e escolha de palavras) nas notícias, para então classificá-las segundo a tipologia. De acordo com Laurence Bardin (1995: 19) a análise de conteúdo trata-se de um conjunto de técnicas de investigação que "tem por finalidade a descrição objetiva, sistemática e quantitativa do conteúdo manifesto da comunicação".

Ainda que nas últimas décadas a técnica tenha sido empregada de diversas formas, há certo consenso sobre cinco de suas características: (i) objetividade: refere-se à explicação dos procedimentos empregados, além da observação aos princípios de validade e confiabilidade; (ii) sistemacidade: analisa o todo de um conteúdo em função de categorias definidas, reduzindose a seleção arbitrária; (iii) conteúdo manifesto: busca reduzir o viés do analista, atentando-se ao conteúdo em si mesmo; (iv) inferência: extração de estruturas traduzíveis em modelos generalizáveis; (v) condições de produção: consideração aos contextos sociais, políticos e históricos, bem como a posição institucional na criação da mensagem.

Dada a abordagem dedutiva do método, por contarmos com uma tipologia já criada, adotamos o tipo de análise que Bardin (1995: 31) chama de análise por categorias. De acordo com a autora, esse tipo classifica um texto "segundo a frequência de presença (ou não) de itens de sentido". Sua utilização não se reduz a um ato descritivo, mas tem um alcance inferencial,

\footnotetext{
${ }^{1}$ Gamson e Modigliani (1989) propuseram originalmente uma tipologia de análise de frames para a cobertura de energia nuclear. Posteriormente, Durant et al. (1998) a adaptou para a biotecnologia e biotecnologia agrícola, que passou a ser utilizada por Bauer et al. (2001); Dahinden (2002); Nisbet \& Lewenstein (2002); Maeseele (2007); Reinhart (2007); Bonfadelli et al., (2007) e Gastrow (2010).
} 
no sentido de que há uma "operação lógica pela qual se admite uma proposição em virtude da sua ligação com outras proposições já aceitas como verdadeiras” (ibidem).

Nessa técnica, o interesse não reside unicamente na descrição dos elementos textuais, mas no que estes podem explicitar, deduzindo-se saberes de conteúdo. A análise por categorias busca encontrar diversos sentidos que o codificador detecta através de indicadores compartilhados entre as categorias em comum, encaixando-os em uma das classes de equivalência em função de um juízo racionalmente justificado.

Empregamos uma forma de análise que verifica a presença de determinada característica em certo fragmento de mensagem, em nosso caso, a presença de elementos textuais das notícias (metáforas, argumentos e escolha de palavras), conforme discutiremos em detalhes no próximo capítulo. Identificamos esses elementos textuais e classificamos as notícias segundo a tipologia detalhada adiante. Um exemplo de aplicação pode ser encontrado no Anexo A.

\subsection{TIPOLOGIA DE FRAMES}

A análise de conteúdo visou identificar a presença dos elementos textuais (ET) nas notícias, o que nos permitiu classifica-las segundo a tipologia de frames escolhida. Ainda que os ET não foram quantificados, a verificação de suas presenças foi responsável pela identificação dos frames. O Anexo A detalha melhor os ET.

A identificação da presença dos ET nas notícias nos possibilitou enquadrá-las segundo a tipologia de frames proposta por Durant et al. $1998^{2}$ :

Progresso: o ponto de partida da celebração do progresso científico e aplicabilidade das inovações na vida cotidiana; uma nova era de desenvolvimento; a celebração da biotecnologia como um produto novo, moderno e disruptivo; uma mudança de direção na história; os conflitos e discussões entre progressistas e conservadores; quando não há impactos e riscos em decisões práticas que utilizam a biotecnologia; a ciência é vista como consultora legítima para decisões sociais em que não há muita clareza; a tecnologia a serviço da sociedade;

Prospecto econômico: quadro que captura as nuances econômicas da biotecnologia, suas aplicações mercadológicas incluindo oportunidades de negócios e novas possibilidades de mercado; o potencial econômico da biotecnologia; prospectos para mercados, investimentos e

\footnotetext{
${ }^{2}$ A tipologia original conta com as seguintes denominações: Progress, Economic Prospect, Ethical, Pandora's box, Nature/nurture, Public accountability, and Globalization.
} 
lucros; desenvolvimento de novos produtos /serviços; o crescimento econômico do país; as perspectivas econômicas dentro da biotecnologia;

Ética: ocorre assim que a biotecnologia é refletida sob o ponto de vista ético, no qual ocorre o contrabalanceamento de prós e contras; quais os melhores caminhos a trilhar; uma chamada para os princípios éticos, limites, fronteiras e distinções de riscos aceitáveis e inevitáveis em contraposição aos riscos conhecidos; mensagens com fundos morais; prescrições sociais; o "brincar de Deus", "interferência na natureza" e semelhantes são frequentemente acionados;

Caixa de Pandora: a aplicação da biotecnologia é tomada como uma ameaça potencial séria se implantada inicialmente ou continuadamente sem clareza acerca das consequências, nesses casos, aconselha-se a interrupção; chamada por limitações frente ao risco desconhecido; a abertura dos portões do perigo; os riscos desconhecidos como ameaças antecipadas; a precaução com catástrofes; a contenção em riscos desconhecidos;

Descontrole: uma aplicação existente é julgada prejudicial e as consequências já são irreversíveis; a biotecnologia deve ser descontinuada para evitar consequências mais graves; fatalismo pós-inovação; uma vez adotada a tecnologia, haverá um preço a ser pago no futuro; perda de controle após evento; cenários apocalípticos inevitáveis;

Natureza: debate sobre a hereditariedade e componentes genéticos dos organismos; ambiente versus determinação genética; questões de herança genética;

Responsabilidade pública: demanda por transparência a respeito dos procedimentos, regulações, mais envolvimento e participação do público; chamada para o controle público e envolvimento nas audiências públicas; quando há discussões em torno dos mecanismos de regulação e legislação; a judicialização dos casos; conflitos de interesse privado versus público; quando governos e outros corpos públicos têm a habilidade de endereçar o problema;

Globalização: chamada para a perspectiva global da biotecnologia; competitividade nacional em um contexto de economia global, ou o contrário (isolamento em um mercado interno); integração mundial do comércio; conflitos e disputas entre nações ou bloco de nações sobre os usos e regulação da biotecnologia; papel estratégico da biotecnologia em um determinado país; cooperação comercial e econômica entre países no uso da biotecnologia.

Seguindo a maior parte das pesquisas de frames de notícia encontradas na revisão da literatura, a unidade de análise empregada foi de um frame por artigo. O Anexo B reúne uma coleção das diferentes definições dadas pelos autores que empregaram a tipologia. 


\subsection{ANÁLISE DOS TEMAS}

Para que pudéssemos identificar quais os itens e assuntos mais frequentes em cada frame, agrupamos as notícias em temas gerais. Em uma primeira etapa, as notícias contavam com um resumo principal, que descrevia genericamente os assuntos tratados. Em uma segunda, mediante a análise de conteúdos por categorias, criamos rótulos que englobassem a maior quantidade possível de assuntos em comum, em um processo à procura de padrões consistentes e lógicos, tais como regras de associação ou sequências temporais. Em uma terceira, repetimos a segunda etapa até que pudéssemos quantificar as informações de modo razoável. Por exemplo: os artigos sobre "contaminação", "novas pragas" e "maior uso de agrotóxicos” foram agrupados em “risco ambiental". Os temas são apresentados no capítulo de análise de resultados.

Na maior parte das vezes, houve a criação de uma categoria genérica que reunia notícias muito específicas ou ainda que não se encaixavam em nenhuma que detivesse um número razoável de notícias passíveis de serem analisadas quantitativamente. Por exemplo: para "Caixa de Pandora", o tema genérico foi "risco não especificado", que deteve $10 \%$ das observações, próximo de "risco à saúde humana", com $12 \%$.

\subsection{ANÁLISE DAS “ONDAS” DE EVENTOS}

Para identificar o conjunto de eventos noticiados em comum que centralizaram o debate, observamos o comportamento de quantidades de notícias, frames, temas e argumentos em períodos específicos. Por exemplo: no quadriênio 1998/2002, ao observar a grande incidência de reportagens que abordavam a judicialização da matéria, a liberação pontual de variedades e safras, pudemos focar nossa atenção no período e descobrir que esse intervalo não havia proibição clara, ao mesmo tempo em que a produção não se constituía crime.

$\mathrm{Na}$ análise de ondas, buscamos compreender os tipos de argumentos, discursos e eventos reportados mais recorrentes, ilustrando-os com a citação de alguns trechos de notícias. Utilizamos a técnica qualitativa análise da enunciação. Seu objetivo é compreender o significado e encontrar a lógica inerente à estrutura da mensagem, já que a manifestação formal pode esconder conflitos. De acordo com Bardin (1995: 170), discurso é qualquer comunicação estudada ao nível da frase em seus elementos constituintes, mas sobretudo a uma transposição à frase (proposições, enunciados, sequências). Assim "perspectivado como processo de elaboração onde se confrontam motivações, desejos e investimentos dos sujeitos com as 
imposições do código linguístico e as condições de produções" (BARDIN, 1995:173). Para isso, Bardin (1995: 170) orienta ao exame das condições de produção de palavra e com as modalidades do discurso mediante a análise sintática e paralinguística, análise lógica e identificação de elementos textuais, tais como estilos de fala, metáforas, metonímias, jogos de palavras, silêncio, omissões, ilogismos e realce das figuras retóricas.

\subsection{GÊNESE DO CORPUS E AMOSTRAGEM}

Escolhemos os jornais digitais Estadão Digital e Folha de S. Paulo/UOL para compor o corpus por figurarem entre os que possuem maior tiragem no país. Nisbet e Huge (2006) seguiram este mesmo critério de hierarquia de notícias ao analisarem os jornais The New York Times e The Washington Post, no qual esses periódicos servem como referência para publicações menores e regionais.

De acordo com dados do site Alexa <alexa.com>, consultados em novembro de 2015, o endereço $<$ folha.uol.com.br $>$ era o vigésimo terceiro em número de acessos no Brasil e o $<$ estadao.com.br figurava $>$ na sexagésima posição.

O portal Folha de S. Paulo <www.folha.uol.com.br> é hospedado no sítio do Universo Online (UOL), empresa de conteúdo pertencente ao Grupo Folha. O jornal impresso $A$ Folha de S. Paulo, segundo dados do Instituto Verificador de Circulação (IVC), possui a maior tiragem do país. Em consulta na seção "dados de mercado" para anunciantes, endossados pelo IBOPE com base nos anos de 2015/16, o perfil médio de seu público é de 55\% masculino e $45 \%$ feminino, com idade entre 25/54 anos e pertencentes às classes A/B. Segundo auditoria da Adobe Analytics, o sítio tem cerca de 29 milhões de usuários únicos por mês. Conforme consulta ao site do Grupo Folha em setembro de 2017, sua missão é:

Produzir informação e análise jornalísticas com credibilidade, transparência, qualidade e agilidade, baseadas nos princípios editoriais do Grupo Folha (independência, espírito crítico, pluralismo e apartidarismo), por meio de um moderno e rentável conglomerado de empresas de comunicação, que contribua para o aprimoramento da democracia e para a conscientização da cidadania.

Já o portal Estadão Digital <www.estadao.com.br> pertence ao Grupo Estado, que veicula o jornal impresso $O$ Estado de S. Paulo, o qual figura entre os cinco jornais de referência no país de acordo com a Associação Nacional de Jornais (ANJ). Em consulta na seção "dados de mercado" para anunciantes, endossados pelo Instituto Ipsos, com base no ano de 2013, o 
perfil médio de seu público é de 56\% masculino e 44\% feminino, com idades entre 25/54 anos e pertencentes às classes A/B. Segundo auditoria da comScore Media Metrix, o sítio tem cerca de 9 milhões de usuários únicos por mês. O código ética do Grupo Estado, consultado em setembro de 2017, afirma que sua missão editorial é:

\begin{abstract}
A missão editorial do Grupo Estado está em grande parte inspirada nos princípios fundadores do jornal Província de São Paulo. Figura na declaração inaugural de propósitos de 4 de janeiro de 1875. No entanto, sensível às mudanças históricas e aos avanços da ética, o Grupo acrescentou ao compromisso com a democracia, a luta pela defesa da liberdade de expressão e de imprensa, a promoção da livre iniciativa, da justiça e a permanente busca da verdade. Comprometido com os valores proclamados na Declaração Universal dos Direitos do Homem, o Grupo Estado está sintonizado com o presente e o futuro dos brasileiros, com a defesa de seus valores culturais, éticos e históricos e a preservação do seu patrimônio natural. Como grupo empresarial do setor de comunicação e informação, persegue a eficiência, a modernidade, a criatividade e a rentabilidade, pré-requisitos da sua independência informativa e editorial. Ademais, comunga com os princípios socialmente responsáveis: geração de riqueza com sensibilidade social e respeito ao meio ambiente.
\end{abstract}

Em ambos os endereços eletrônicos de comercialização do Grupo Folha e do Grupo Estado, os portais são comunicados como réplicas de suas versões impressas. Em contatos telefônicos com as áreas comerciais dos grupos realizados em $02 / 02 / 2016$, foi confirmado que os portais são "espelhos" de seus jornais impressos, contendo as principais notícias, algumas vezes de forma reduzida ou editada. Também podem contar com artigos atualizados em tempo real, apresentando versões incompletas na hora de sua publicação, geralmente sendo corrigidas ou complementadas posteriormente.

O recorte temporal foi definido a partir de 1998, quando foi dado o parecer técnico favorável pela CNTBio ao cultivo da soja $R R$, havendo aumento expressivo do número de notícia. Durante a coleta de dados, ambos os portais não apresentaram notícias sobre o tema anteriores ao ano de 1998. Outras culturas foram liberadas ao longo do tempo, até a sanção da Lei 11.105 em 2005, conhecida como Lei da Biossegurança. Nos anos seguintes observamos ainda conflitos, motivo pelo qual julgamos conveniente o recorte até 2015.

Utilizamos o software Microsoft Office Excel para Mac v.15.32 para tabulação dos dados, análise das notícias e confecção de gráficos/tabelas. Empregamos o pacote estatístico IBM SPSS para Mac v.15.1.0.0. (Statistical Package for the Social Sciences) para identificação mais célere de algumas estatísticas e mineração dos dados.

Uma pesquisa que se propõe a analisar um amplo recorte temporal naturalmente traz grandes desafios para definir uma amostra representativa. A situação é ainda mais delicada pelo fato da tipologia extrair somente dados tipo nominal (rótulo), tornando inviável estimativas a 
partir de parâmetros amostrais (ex.: desvio-padrão, variância) para amostragem probabilística em populações desconhecidas. Outra dificuldade ocorre em razão da impossibilidade de se determinar todos os termos e palavras-chave capazes de recuperar o universo de notícias sobre organismos transgênicos.

Apesar dessas adversidades, buscamos alternativas para garantir rigor em uma amostragem representativa. Aplicamos uma amostragem estratificada, que, de acordo com Correia (2011: 76), trata-se de uma amostra representativa devidamente justificada em critérios objetivos e que se baseia nas características gerais do universo de notícias. Utilizamos somente a palavras-chave "transgênicos" nos motores de busca dos portais, por notarmos que esse termo é o que possui maior assertividade para nosso objetivo. A seguir, descrevemos os crivos para determinar se uma notícia era substancialmente relacionada ao nosso objeto:

- Biotecnologia vermelha: notícias relacionadas às áreas de mapeamento genético, órgãos humanos e outros procedimentos relacionados à área da saúde. Exemplo: "empresa de biotecnologia testará Aedes aegypti transgênico", "sangue transgênico já é realidade" e "coração transgênico pode ser apresentado nas próximas décadas".

- Cartas de leitores destinadas aos portais: apareciam nos resultados de busca alguns comentários enviados em meio digital por leitores se posicionando frente a alguma notícia que abordou os transgênicos. Diferentes de artigos de opinião, em houve o destaque de autoridades e outros atores importantes, as cartas somente compilavam comentários dos leitores.

- Notícias duplicadas: em portais muitas vezes não há tempo suficiente para realizar a revisão e jornalistas só percebem erros depois da publicação, sendo comum o aviso "notícia atualizada" informando a data de edição ou errata. Há ainda a ocorrência de manchetes que são ligeiramente modificadas, mas o conteúdo é o mesmo. O portal FSP foi especialmente sensível a esse revés. Um exemplo encontrado no portal do Estado:

- Transgênicos como suporte para outros argumentos: notícias em que os transgênicos são tomados meramente para argumentar algo não relacionado ao tema. Ex: em uma notícia com mais de dez parágrafos sobre a necessidade de investimentos no campo, os transgênicos ocorriam somente uma vez como exemplo de tecnologia.

- Fóruns, congressos e conferências: quando em conferências, congressos, fóruns e debates gerais, nacionais e internacionais, havia a citação do termo "transgênicos". Caso a notícia não abordasse a questão de forma capaz de promover certo quadro, era descartada da análise. 
Por meio da palavra-chave "transgênicos", localizamos um universo total de 6.143 notícias no período de 1998 a 2015 (2.314 no Estado e 3.829 na Folha). Com base nos demais critérios e itens da tipologia adotada, chegando ao valor de 1.396 notícias. Ressalta-se que grande parte das notícias recuperadas eram proveniente de duplicações por questões de erros de sistema ao mesclar as notícias corrigidas. O anexo D traz maiores detalhes e link para download da tabulação completa dos dados.

Após discutirmos esses pontos, podemos dizer que, embora nossa amostra não possa ser considerada como probabilística, pois é impossível determinar o universo de notícia, os cuidados de seleção de artigos nos possibilitaram construir um corpus representativo da pauta transgênicos no período de 1998 a 2015. 


\section{MÍDIA, FRAMES E PROBLEMAS AMBIENTAIS}

\subsection{CONSTRUÇÃO DE PROBLEMAS SOCIOAMBIENTAIS}

As primeiras notícias sobre os riscos associados aos transgênicos foram reportadas em diferentes localidades do mundo, a partir da década de 1990, momento em que se iniciou a produção comercial em escala em alguns dos principais países agroexportadores: Estados Unidos (1994), Canadá (1995), Japão e Argentina (1996), México (1997) e Brasil (1998). Anos antes, o viés que vislumbrava um novo marco de desenvolvimento era a tônica prevalecente na grande mídia. Mas por quais razões a pauta do risco passou a ter espaço nos grandes jornais? Quais são as condições para o surgimento do debate para um risco ambiental? Por que alguns quadros de notícia para os transgênicos são inexpressivos em certo momento e em apenas alguns anos passam a figurar dentre os principais?

Optou-se por responder esses questionamentos tratando os possíveis riscos associados aos transgênicos como um problema ambiental, principalmente com base nas premissas encontradas na sociologia construcionista. Nessa linha, a aparição de problemas ambientais nas esferas públicas é intimamente relacionada com a percepção que os vários grupos da sociedade têm deles em uma visão da natureza a partir de uma perspectiva cultural. Isto é, problemas ambientais passam a ter uma "existência social" e a influenciar na vida cotidiana dos indivíduos quando são reconhecidos como importantes.

Muitos dos construcionistas se inspiraram em alguma medida em Berger e Luckmann (1985 [1966]), conhecidos por difundirem o conceito de "construção social de realidades". Influenciados pela etnografia de Alfred Schütz sobre o conhecimento e pelas ponderações durkheimianas de instituições, Berger e Luckmann (1985) refletiram sobre o modo pelo qual os significados subjetivos dos indivíduos poderiam se consubstanciar em fatos sociais ${ }^{3}$. Para isso, eles se apoiaram no axioma de que a sabedoria humana se explica por meios das interações intersubjetivas de indivíduos e grupos, construindo-se uma pequena cultura na qual os significados são amplamente compartilhados.

Nessa abordagem, o conhecimento socialmente construído seria uma espécie de ponte entre o mundo material e a realidade imaginada. Uma realidade imaginada é algo em que um

\footnotetext{
${ }^{3} \mathrm{Na}$ sociológica clássica, fato social é geralmente definido como os instrumentos e condições sociais e culturais que determinam o agir, pensar e sentir dos indivíduos
} 
grupo social acredita e, enquanto esse conjunto de crenças partilhada persiste, a realidade criada exerce influência na experiência cotidiana. Por exemplo, há certo consenso entre geólogos e arqueólogos que o Planeta Terra já passou por cinco ou seis extinções em massa, quando grande parte das espécies se extinguiu em um curto período de tempo. Atualmente, há grupos de cientistas que defendem que estaríamos passando por uma nova, dada a ação antropogênica (e.g., poluição de águas/solos, superexploração de recursos, destruição da camada de ozônio e mudanças climáticas). O reconhecimento dessa nova extinção dependeria da ampla aceitação dessa realidade intersubjetiva que, apreendida como uma verdade cabal, motivaria as pessoas a buscarem novas maneiras de se relacionarem com a natureza.

Assim, o processo de construção de realidades pode ser considerado por excelência um fato social. Isso pois a construção de uma realidade é inexorável aos contextos sociais, políticos e culturais nas quais ela emerge. Em uma sociedade multifacetada, policêntrica e complexa, com diversas clivagens e cada qual dotada de critérios de validade para explicar o mundo, é de se esperar que as dinâmicas intersubjetivas sejam marcadas pela coexistência de conhecimentos singulares que, ora ou outra, vêm a ser paradoxais. Daí a ênfase do construcionismo nas interações dos que são os construtores da realidade. E é justamente nessa relação intersubjetiva entre distintos atores, com seus pacotes de interpretação sui generis, que a realidade imaginada será construída, reconhecida, negociada, legitimada e disseminada.

Em Social Problems: a Re-Formulation, Malcolm Spector e John Kitsue (1973) tomaram a inciativa de analisar os problemas mais gerais que uma sociedade enfrenta sob uma nova perspectiva: notaram que a percepção de um problema social, face à sua descrição material em termos técnicos, é o que deveras motivaria grupos e indivíduos a se relacionarem com ele. A ideia foi inovadora, uma vez que foi reconhecido que são as ações para a percepção de um problema que realmente influenciam a vida social. Spector e Kitsue (1973: 145) listam quatro etapas peculiares na construção de um problema social: (i) grupos vulneráveis reconhecem uma situação específica desigual e exigem seus direitos; (ii) instituições formais respondem a tais exigências; (iii) há insatisfações com a resposta formal, havendo um novo ciclo de exigências; (iv) uma alternativa é acordada.

Para Cynthia Enloe (1975), nem o conhecimento científico nem grupos sociais notáveis são os fatores determinantes na construção social de um problema ambiental. Ao invés, cinco fatores são decisivos, quando: (i) estimula a atenção midiática; (ii) envolve algum tipo de apoio governamental; (iii) demanda decisões governamentais; (vi) não é vista como algo insano e; (v) é relacionada a um grande número de cidadãos (ENLOE, 1975: 21). Em 1975 a atuação da 
mídia já é reconhecida como crucial na construção de problemas. A capacidade que a mídia tem de estruturar o debate público, legitimar as vozes mais corretas e disseminar informações a um grande número de pessoas influencia diretamente na formação da opinião pública, que tende a demandar exigências de regulares.

John Hannigan (2006: 63), um dos expoentes da área, observa que um problema ambiental se mantém "invisível” até que indivíduos ou grupos notáveis se articulam para legitimá-lo como tal. Isso significa que as formulações dadas pelos atores que detêm maior legitimidade no assunto tendem a ser tomadas como verdade e, portanto, são mais importantes que a própria descrição do problema ambiental em termos técnicos. Assim, a discussão de uma questão ambiental no espaço público não emerge seguindo um conjunto de critérios óbvios ou indiscutíveis. Mas a partir de concepções simbólicas, cujas definições se dão como resposta a "exigências" formuladas por cientistas, especialistas, políticos, ambientalistas, oficiais do governo, industriários, dentre outros atores notáveis.

Hannigan (2006) lista seis condições para que problemas ambientais sejam objetos de atenção pública na mídia: (i) uma autoridade científica que valide as reivindicações; (ii) a existência de divulgadores que estabelecem uma ponte entre ambientalismo e ciência; (iii) a atuação da mídia para que o problema seja enquadrado como novidade; (iv) a dramatização do problema em termos visuais e simbólicos; (v) incentivos econômicos para adoção de ações de suporte e; (vi) o recrutamento de um patrocinador institucional que continue o processo. $\mathrm{O}$ autor propõe um modelo conceitual (Tab.1).

Cada uma dessas tarefas-chave montagem, apresentação e contestação transita por diferentes arenas sociais em que há o predomínio de determinadas atividades, estratégias e tipos de argumentos. De acordo com Hannigan (2006: 115), arena social "é uma metáfora para a organização política na qual diferentes atores direcionam suas exigências para tomadores de decisão na esperança de influenciar o processo decisório".

Em montagem, conceitos disruptivos nunca antes debatidos emergem, causando muitos desentendimentos. A arena científica é a mais importante nessa etapa, por isso, há certa estranheza para a maioria das pessoas. Em apresentação, os meios de comunicação têm o papel de selecionar o que os atores exigem como um problema novo, conferindo-lhes alguma legitimidade. A arena midiática é a mais importante, disseminando as informações do problema. Por último, em contestação, a mídia simplesmente atua como reprodutora da arena política. Não basta exigir a existência de um problema para um grande número de indivíduos, 
é necessário que reguladores efetivamente discutam as políticas a serem adotadas.

Tabela 1 - Tarefas-chave na construção de problemas ambientais

\begin{tabular}{|c|c|c|c|}
\hline \multirow{5}{*}{ Atividades primárias } & \multicolumn{3}{|l|}{ Tarefas } \\
\hline & Montagem & Apresentação & Contestação \\
\hline & $\begin{array}{l}\text { Descobrimento o } \\
\text { problema }\end{array}$ & Liderando a atenção & Invocando ações \\
\hline & Nomeando o problema & $\begin{array}{l}\text { Legitimando a } \\
\text { exigência }\end{array}$ & Mobilizar suporte \\
\hline & $\begin{array}{l}\text { Determinando os } \\
\text { fundamentos de } \\
\text { reivindicações }\end{array}$ & & Defender a propriedade \\
\hline Arena Central & Comunidade científica & Mídia de massa & Política \\
\hline Principal natureza das provas & Científicas & Morais & Legal \\
\hline $\begin{array}{l}\text { Papel predominante da } \\
\text { ciência }\end{array}$ & Detector de tendências & Comunicador & $\begin{array}{l}\text { Analisar políticas } \\
\text { aplicadas }\end{array}$ \\
\hline \multirow[t]{3}{*}{ Ciladas em potencial } & Falta de clareza & Baixa visibilidade & Cooptação \\
\hline & Ambiguidade & $\begin{array}{l}\text { Declínio do interesse } \\
\text { pela novidade }\end{array}$ & Exaustão da questão \\
\hline & Controvérsia científica & & $\begin{array}{l}\text { Argumentos em } \\
\text { contrapartida }\end{array}$ \\
\hline \multirow[t]{3}{*}{ Estratégias de sucesso } & $\begin{array}{l}\text { Criar focos } \\
\text { experimentais }\end{array}$ & $\begin{array}{l}\text { Ligar a causas e } \\
\text { questões populares }\end{array}$ & $\begin{array}{l}\text { Redes de } \\
\text { relacionamento }\end{array}$ \\
\hline & $\begin{array}{l}\text { Simplificar } \\
\text { conhecimentos e } \\
\text { reivindicacões }\end{array}$ & $\begin{array}{l}\text { Uso de falas dramáticas } \\
\text { e imagens chocantes }\end{array}$ & Desenvolver técnicas \\
\hline & & $\begin{array}{l}\text { Estratégias e táticas } \\
\text { retóricas }\end{array}$ & $\begin{array}{l}\text { Abertura a propostas } \\
\text { políticas }\end{array}$ \\
\hline
\end{tabular}

Fonte: Adaptado de Hannigan (2006: 68)

Robert Cox e Stephen Depoe (2015: 14) oferecem algumas premissas nas relações entre comunicação, jornalismo e questões ambientais. Em sua análise, qualquer construção social da natureza (discursos, imagens e frames) é essencialmente uma representação simbólica, que depende dos contextos sociais, culturais e ideológicos nos quais ela ocorre. Dessa forma, a orientação construcionista deve se ater à criação e institucionalização das realidades mediante as interações sígnicas entre indivíduos. Isto é, independente do que seja a realidade material, são essas interações, muitas delas marcadas pelo embate dialético entre concepções distintas, que criam os signos para a representação das coisas do mundo. Por consequência, o cerne de qualquer problema ambiental é fruto da ação coletiva de vários agentes que visam atribuir sentidos à questão. 
Por isso que Cox e Depoe (2015) afirmam que para que haja a ampla compreensão de problemas ambientais é preciso, em primeiro lugar, partir do pressuposto de que eles são construídos mediante discursos que representam o mundo natural. Em segundo, que tais representações incorporam certos posicionamentos que refletem interesses sociais, econômicos ou ideológicos. Por fim, que os atores circunscritos em diferentes contextos podem manter, questionar ou desafiar interpretações dominantes sobre os problemas. Portanto, a compreensão da comunicação de problemas ambientais na mídia serviria, em última instância, para fortalecer a capacidade de decisão coletiva em uma sociedade.

Alison Anderson (1997), a partir da síntese de várias pesquisas empíricas, observa que a grande imprensa tende a cobrir com maior frequência eventos mais concretos e factuais em vez de problemáticas que apelam para abstrações conceituais. As problemáticas intangíveis, pela ausência de materialidade, costumam ser mais difíceis de serem compreendidas, por isso tendem a ser reportadas de modo mais difuso ao longo do tempo. Já acontecimentos factuais são mais fáceis para a compreensão de relações de causa e efeito por parte da audiência, portanto, mais ligados à vida cotidiana.

Anderson (1997) apresenta cinco fatores que têm o potencial de promover uma notícia ambiental: (i) frequência, (ii) amplitude do nível de amplificação de um evento, (iii) relevância em termos de proximidade cultural e relação com a vida cotidiana, (iv) conformidade com ideia pré-concebidas sobre um grupo social ou uma narração raridade, raridade, continuidade e (v) poder competitivo. Esse ponto de Anderson (1997) é pertinente, pois a participação de somente especialistas na construção de temas ambientais é diminuída, privilegiando regras institucionais de noticiamento relativamente independentes. Isso não significa que especialistas não sejam importantes, mas que eles têm maior chance de terem maior protagonismo caso estejam em conformidade com esses critérios que moldam a notícia. Na próxima seção, quando revisarmos a literatura de newsmaking, esses aspectos de produção de notícias ficarão mais claro.

Anthony Downs (1972) se propôs a descrever o fenômeno de ciclos de altas e baixas na atenção coletiva para problemas ambientais. O autor chega a cinco estágios: (i) problema a priori: quando especialistas o expõe; (ii) descoberta: quando a grande audiência conhece o problema; (iii) percepção de custos: quando são identificados custos financeiros e não financeiros para resolver o problema; (iv) declínio do interesse: quando a temática passa a ficar técnica demais e não captura a atenção pública e; (v) problema a posteriori: quando o problema é anexado a uma pauta da sociedade, havendo maior probabilidade de ser retomado caso aconteça algum evento específico relacionado. 
Nos estágios de descoberta e percepção de custos, pesquisas empíricas para a mídia, a exemplo da realizada por Nisbet e Huge (2006), observam que há massiva maioria de frames dramáticos em detrimento de técnicos, havendo a participação de diversos atores leigos nas discussões. Justamente nos estágios em que leigos dominam as notícias, verifica-se maior número de notícias e interesse pela audiência. Em outras palavras, caso os atores interessados na construção de um problema ambiental não traduzam suas exigências em informações cativantes para a audiência leiga, talvez sua influência não seja tão intensa.

Libby Lester (2010), tal como Hannigan (2006), considera a mídia como uma arena social, concentrando-se na pluralidade dos vários atores sociais bem como de suas ações e estratégias adotadas para que suas definições sejam amplamente aceitas. Baseada em uma série de pesquisas, Lester (2010) tem observado que, cada vez mais, tais atores têm povoado o debate midiático sobre problemas ambientais e por isso ele tende a tornar-se mais institucionalizado. Assim, fontes e entrevistados (independente de serem mais ou menos legítimos) formariam a parte mais relevante para se compreender notícias sobre o ambiente. Como ela argumenta, uma pauta ambiental é passível de se tornar notícia quando grande parte da sociedade é consciente de como ela abala sua vida. Nessas condições, uma diversidade de atores competirá pelo valor de verdade da melhor interpretação que impacte na vida cotidiana (LESTER, 2010: 102).

Em síntese, Hannigan (2006) enfatiza o viés científico na construção de um problema ambiental. Por conta disso, o autor foca a identificação da influência de atores legítimos, ainda que não haja consenso absoluto entre especialistas. Apesar disso, Anderson (1997), Cox e Depoe (2015), Nisbet e Huge (2006) e Lester (2010) que se debruçaram mais sobre os meios de comunicação, apontam que, quando uma quantidade massiva de indivíduos leigos está em jogo, as opiniões não-científicas podem apresentar maior influência em sua definição (Tab. 2).

Esses autores igualmente reconhecem certos fatores institucionais da mídia que se comportam como gatekeepers da produção de notícia. Ora, caso uma reportagem não desperte o interesse da audiência, não seja disseminada com certa frequência e amplitude, não siga critérios de noticiabilidade e narrativização que mais capturam a atenção do público e os acontecimentos não possuem certos "valores notícia"4 dificilmente a pauta de problemas ambientais entrará na agenda das discussões públicas. A próxima seção trata um pouco mais desses critérios e fatores de noticiabilidade.

\footnotetext{
${ }^{4}$ Para jornalistas, uma disputa política é mais atraente para se transformar em uma notícia do que um alerta cheio de jargões técnicos de um cientista. A próxima seção detalhará melhor o conceito de valor notícia.
} 
Tabela 2 - Resumo dos autores

\begin{tabular}{ll}
\multicolumn{1}{c|}{ Autor } & \multicolumn{1}{c}{ Fatores institucionais para uma notícia ambiental } \\
\hline Hannigan ([1995] 2006) & $\begin{array}{l}\text { Autoridade científica que legitima } \\
\text { Uso de falas dramáticas } \\
\text { Imagens chocantes } \\
\text { Táticas retóricas }\end{array}$ \\
Anderson (1997) & $\begin{array}{l}\text { Frequência e amplitude da mensagem } \\
\text { Proximidade cultural e com a vida cotidiana } \\
\text { Conformidade com ideias já pré-concebidas }\end{array}$ \\
Nisbet and Huge (2006) & Linguagem que seja acessível a leigos \\
Lester (2010) & Impacto na vida cotidiana \\
Cox e Depoe (2015) & Quando acionam padrões sígnicos já legitimados
\end{tabular}

Fonte: síntese da literatura pelo autor.

\subsection{NEWSMAKING E A CONSTRUÇÃO SOCIAL DE REALIDADES}

A área de pesquisa em jornalismo conhecida por newsmaking se assemelha em muitos aspectos às proposições do construcionismo, alguns de seus principais autores são, de fato, referenciados como construcionistas, construtivistas ou ainda "sociólogos da notícia". Em linhas gerais, o newsmaking é orientado para o estudo das rotinas de produção e dos produtores da notícia, analisando recursos jornalísticos empregados, contextos sociais, culturais e políticos, historicidades, constrangimentos organizacionais e condições de produção na reportação dos acontecimentos. Nessa abordagem, a definição de pauta, a seleção de fontes e entrevistados e a escolha por critérios de noticiabilidade determinariam a forma e o conteúdo das notícias.

A partir da década de 1970, notáveis pesquisadores do jornalismo passam a adotar as teorias da sociologia construcionista. Nesse contexto, as notícias começam a ser vistas como objeto de disputa simbólica, ou seja, diferentes grupos agiriam para que seus pontos de vista, em detrimento de outros, fossem reportados. Por sua vez, jornalistas tenderiam a noticiar as visões de mundo mais consagradas. Não mais por uma questão de dominação, como afirmavam críticos marxistas, mas por motivos mais práticos: em uma economia de livre mercado, caso as reportagens não retratassem as realidades mais aceitas, as empresas jornalísticas não passariam 
credibilidade e, consequentemente, se inviabilizariam financeiramente.

Apesar do reconhecimento de muitos dos construcionistas de que haviam claras assimetrias de poder entre atores na imposição de seus quadros interpretativos e ideologias na produção de notícias, as evidências empíricas não conseguiam provar o poder de influência direta da mídia nas mentes das pessoas. Tampouco provavam o conluio de um grupo dominante formalmente articulado e muito menos demonstravam um aparelho ideológico operado por um Estado burguês destinado à dominação das classes operárias.

De modo igualmente distinto do instrumentalismo, que pregava a neutralidade da mídia, os construcionistas passam a declarar que a notícia não espelhava a realidade tal como ele é. Ao invés disso, a notícia seria explicada por meio de uma determinada "estrutura jornalística", que definiria a priori as maneiras pelas quais os eventos noticiáveis poderiam transformar-se em reportagens. Essa estrutura resultaria da interação de múltiplos atores que pleiteiam impor suas visões de mundo na ordenação de sentido nos fatos.

Para Nelson Traquina (2004: 107), o newsmaking é interessado nas ações pelas quais atores lutam para impor suas posições, ao mesmo tempo em que institucionalizam as rotinas de produção de notícias. Partindo de Pierre Bourdieu (1997) que: "Jornalistas têm os seus óculos particulares dos quais veem certas coisas e não outras; veem de uma certa maneiras as coisas que veem. Operam uma seleção e uma construção daquilo que é selecionado" (BOURDIEU, 1997 apud TRAQUINA, 2004). Traquina (2004) esclarece que esses “óculos particulares", cuja mídia elege como destaques no noticiário, fazem parte de discursos estruturados. Discursos que são coletivamente construídos pela tensão entre os atores que os pronunciam com embasamento em seus vieses, vícios e compreensões do acontecimento. Desse modo, a notícia é fruto de um processo profissionalmente organizado nos contextos social, cultural e político em que o jornalista está inserido. Para Traquina (2004), o newsmaking pode ser definido como a percepção, a seleção e a transformação de uma matéria-prima (acontecimentos) em um produto cultural (notícias).

Já Gaye Tuchman (1978) compreende as notícias de jornais como um conglomerado fenomenológico em duas dimensões de ações: cognitivas e perceptivas. Pela dimensão cognitiva, as notícias são tomadas como meios institucionalizados de informar sobre os acontecimentos através de jornais, revistas, rádio e televisão, isto é, meios que são consumidos pela audiência. Por sua vez, a dimensão perceptiva ocorre quando a produção da notícia se dá por práticas de rotinas institucionalizadas. Isso quer dizer que, se por um lado as notícias são um produto de consumo cultural, por outro, há uma estrutura institucional com regras e 
preceitos próprios que determinariam o enquadramento dos eventos. Tais estruturas, portanto, por meio de princípios de organização, seleção e definição, enquadrariam os acontecimentos na forma de notícias (TUCHMAN, 1976: 94).

À primeira vista pode parecer um paradoxo uma autora do newsmaking afirmar que os atores não os senhores de si na construção social de uma notícia, visto que certa estrutura delimitaria suas ações. Porém, apesar de os princípios advirem de práticas institucionalizadas, eles não se mostram inerentemente estáticos. Na verdade, são negociados entre uma pluralidade de atores. Tuchman (1978) enfatiza que toda representação se caracteriza pela multiplicidade de interesses, em uma relação interativa que culminaria no modo de fazer das reportagens. Portanto, ao mesmo tempo em que jornalistas, fontes e entrevistados são constrangidos e influenciados pela estrutura jornalística, eles são livres para agir e mudar a estrutura, definindo novos critérios de noticiabilidade.

Mauro Wolf (2005 [1987]) enfatizou os atributos que caracterizariam um acontecimento noticiável, ao perceber que a avaliação e a seleção dos aspectos a serem noticiados se dá por condicionantes objetivos na forma de critérios de noticiabilidade. Por trás destes, estaria a resposta ao questionamento sobre quais fatos deveriam se tornar notícias:

A noticiabilidade seria constituída pelo complexo de requisitos que se exigem para os eventos - do ponto de vista da estrutura do trabalho nos aparatos informativos e do ponto de vista do profissionalismo dos jornalistas -, para adquirir a existência pública de notícia (WOLF, 2005: 196).

Assim, de acordo com Wolf (2005), para se classificar os requisitos exigidos para que um evento se torne notícia, deve-se considerar seus "valores notícia", compreendidos como a qualidade cuja presença pode recomendar a um jornalista a criação de um produto informativo. Nesse sentido, os padrões de noticiabilidade que reproduzem as ideias mais aceitas direcionariam os modos pelos quais os fatos são enquadrados. Assim como Tuchman (1976), o autor reconhece que tais valores não são fundamentados por elementos inexoravelmente vinculados aos eventos, são socialmente construídos: “o produto informativo parece ser resultado de uma série de negociações, orientadas pragmaticamente, que têm por objeto o que deve ser inserido e de que modo deve ser inserido no jornal" (WOLF, 2005: 200).

Como se pode ver, no cerne do newsmaking está a noção de que a representação dos ideais de uma realidade é socialmente construída. Em um primeiro momento, o jornalista busca pautas com certos valores notícias. Em um segundo, tais valores são moldados por diferentes forças exógenas que emanam poder sobre o ato jornalístico, isto é, se determinado aspecto é 
amplamente aceito, o jornalista deve de algum modo abordá-lo. Em um terceiro, dada a infinidade de enquadramentos possíveis da realidade, os jornalistas têm o desafio de selecionar e produzir mensagens passíveis de serem compreendidas pela instância da audiência, por isso acionam padrões de organização cultural criados a priori.

Um ponto elementar levantado pelo newsmaking reside no fato de que eles priorizam em suas pesquisas as rotinas de produção e regras institucionais que constrangem o "ato fazer notícia", deixando à margem ações, alianças, mobilizações e estratégias dos atores nos conflitos sociais em arenas que definem a construção da realidade. Nem por isso ele despreza a noção de que as rotinas, os critérios de noticiabilidade, os valores notícia e os aspectos que serão objeto de notícia são negociados entre atores e, portanto, socialmente construídos.

Em síntese, na dinâmica de construção da realidade, reverberam-se certas ações de atores nos bastidores da reportação dos acontecimentos. Por isso, muito longe de uma reprodução fiel e objetiva dos eventos, a notícia é construída sob olhares que foram a priori reivindicados, disputados e vencidos. A mídia, ao servir-se de certos critérios de noticiabilidade e padrões culturais já legitimados, tem muito mais chance de seduzir a instância da recepção. $\mathrm{Na}$ próxima seção, detalharemos os processos de organização de acontecimentos e nosso envolvimento subjetivo com eles: a teoria de frames.

\subsection{ORGANIZAÇÃO DA EXPERIÊNCIA EM FRAMES DE NOTÍCIA}

Ao final do ano de 1968, em Chicago (EUA), ativistas do movimento Students for a Democratic Society (SDS) protestavam veementemente com a frase "o mundo todo está assistindo" às portas da Convenção Nacional do Partido Democrata. Todd Gitlin, sociólogo que vinha acompanhando a cobertura midiática para o movimento, ficou fascinado com um padrão: nos anos anteriores, os grandes jornais pareciam reportar as ações do SDS como isoladas e sem repercussão relevante na sociedade americana.

Entretanto, a partir de 1968, houve expressivo aumento no noticiamento das reivindicações do grupo, impulsionando a consciência coletiva de outros estudantes ao redor de todo os Estados Unidos que, por fim, elevou substancialmente a adesão ao movimento. As notas do evento foram documentadas posteriormente em sua obra The Whole World is Watching! (1980), na qual Gitlin demonstra como as representações midiáticas têm efeitos cruciais na promoção de determinadas nuances da realidade (BOYKOFF, 2014). Os conceitos 
apresentados, juntamente com as contribuições de outros autores, têm guiado a compreensão das adjacências entre política, mídia, opinião pública e mobilização coletiva.

Cabe dizer ainda que a teoria de quadros foi proposta primeiramente pelo antropólogo Gregory Bateson no campo da Psicologia, mas sofisticada como conceito sociológico por Ervin Goffman em 1974. Aplicando algumas metáforas do teatro para a explicação da organização da experiência social, Goffman (1986 [1974]) notou que indivíduos ocidentais têm seus papéis sociais constrangidos pelos contextos culturais e sociais a sua volta. Para Goffman (1986: 21), um quadro é um conjunto de conceitos que organiza as experiências cotidianas e, dessa maneira, orienta as ações de indivíduos e grupos sociais. Nas palavras do autor:

Parto do pressuposto de que as definições de uma situação são construídas de acordo com os princípios de organização que governam os acontecimentos - pelo menos aqueles que são sociais - e nosso envolvimento subjetivo com eles; frame é a terminologia que utilizo para me referir aos elementos básicos que sou capaz de identificar. (GOFFMAN, 1986: 10).

As proposições de Goffman (1986) se estabeleceram como um marco porque até então sociólogos se dedicavam a explicar a estrutura social ao invés de se concentrarem na organização da experiência humana. A análise de frame (AF), de acordo com o autor, é uma maneira de "se referir ao exame desses quadros" (GOFFMAN, 1986: 10).

Abrindo precedente para toda uma tradição de pesquisa em comunicação, em um dos vários exemplos de enquadramento da realidade, Goffman (1986: 15) já citava as notícias de jornais. Mas a primeira apropriação metodológica da AF para a mídia foi a de Gaye Tuchman em 1976, com grandes contribuições de Gitlin (1980) e Entman (1993). Desde então, esse método tem sido tão bem-sucedido que, segundo Borah (2011), mais de 60\% dos artigos embasados na teoria de frames têm examinado notícias. Bryant e Miron (2004), ao verificarem importantes periódicos da área da comunicação, demonstraram que a AF foi a abordagem mais utilizada em sua época. Scheufele e Iyengar (2012) notaram a presença recorrente de estudos desse tipo na maioria das revistas científicas internacionais mais citadas.

Segundo Gaye Tuchman (1978), frames de notícia são esquemas interpretativos mediados, socialmente construídos, capazes de delimitar e estruturar quais aspectos de uma notícia serão destacados. Dessa maneira, quando um quadro impõe certa ordem sobre os acontecimentos, jornalistas acabam reduzindo a variabilidade de abundância dos eventos (TUCHMAN, 1978: 71), alimentando assim o ciclo de consolidação de frames já legitimados. 
Nas considerações de Tuchman (1978), é enfatizado o aspecto de narrativização mediante os frames, ou seja, ao reportar uma história, jornalistas ajustam os frames aos seus entendimentos, estilos, ideologias, linhas editoriais, opiniões e limitações práticas (espaço e tempo) a respeito da questão. Por conseguinte, por meio dos processos de enquadramento, a mídia delimitaria, enfatizaria e ignoraria aspectos da realidade.

Gitlin (1980), inquietado pela capacidade da cobertura midiática de influenciar a mobilização dos movimentos norte americanos de esquerda, acrescenta que frames atuam como abstrações tácitas do que existe, acontece e importa. E vai além: "não devemos tomar como certo que o mundo retratado [na mídia] é o mundo que existe" (GITLIN, 1980: 6). Para ele, frames são padrões persistentes de interpretação, ênfase e exclusão, através dos quais os detentores de símbolos organizam os discursos da mídia. Para o autor, frames conduzem o debate midiático, delimitando algumas das definições da realidade em disputa.

Robert Entman, por sua vez, (1993) teve como uma grande contribuição para o campo uma das definições mais citadas:

\footnotetext{
Enquadrar é selecionar alguns aspectos da realidade percebida e fazê-los mais salientes em um texto comunicacional, de forma a promover uma definição particular para o problema, uma interpretação causal, uma avaliação moral e/ou uma recomendação de tratamento (ENTMAN, 1993: 52).
}

A análise de frames poderia ser utilizada, então, para a compreensão das narrativas jornalísticas, levando em consideração que repórteres não fazem simplesmente a retratação de um acontecimento e jornalistas definem os amorfos que fazem parte dos eventos noticiáveis.

É importante ressaltar que tanto as definições de Gitlin (1980), Tuchman (1978) e Entman (1993) são intimamente relacionadas ao campo da comunicação e política, levando em conta a função social da mídia de agendadora das questões públicas mais relevantes. Nessas análises, nota-se uma forte participação da mídia no subsídio de informações selecionadas na construção de problema ambientais, limitando e organizando suas definições. Tal delineamento da realidade, portanto, se serve não de toda a vastidão das possibilidades de explicação do mundo. Mas preferencialmente aquelas que não contradizem com os quadros dominantes.

\subsection{INDEFINIÇÃO DE UM CONCEITO}

Embora consista em ampla área de pesquisa, o campo de quadros tem sofrido duras críticas quanto à falta de padronização entre os autores nas fundamentações teóricas de suas 
principais premissas, não raramente contraditórias (PORTO, 2004: 77). Além disso, a própria conceituação de frame tem se mostrado uma variável abstrata (SAPERAS \& CAMPOS 2015), com excessivas dificuldades de identificação por análises textuais, comprometendo a validade dos métodos empregados (GORP, 2005: 503).

Thomas Koenig (2004) observa que as análises de quadros realizadas hoje já se distanciaram muito das formulações originais de Goffman, apresentando não raramente uma ligação fragilizada. Kimberly Fisher (1997) é enfática sobre a falta de consenso e conformidade entre autores, incluindo a própria definição conceitual do que é um frame. Diante dessas adversidades, vem sendo relatadas nos últimos anos um conjunto de tentativas a garantir maior rigor metodológico. Na seção seguinte, discutiremos algumas delas.

\subsection{VALIDADE E CONFIABILIDADE PARA FRAMES}

Zhondang Pan e Gerald Kosicki (1999: 58) preocupam-se em diferenciar a análise de frames das análises tradicionais de textos, embora considerem que a primeira se aproprie de muito dos elementos da segunda. Primeiramente, a AF não conceberia os textos noticiosos em uma perspectiva psicológica, a qual identifica significados objetivos. Em vez disso, as notícias são tidas como consistências de dispositivos simbólicos que interagirão com a memória de atores individuais na construção dos sentidos. Dito de outro modo, o conteúdo da notícia abrigará uma série de representações sígnicas que acionarão padrões de interpretação cultural (frames) já presentes nas mentes dos leitores.

Em segundo lugar, a análise de quadros não se concentraria nas fontes emissoras tampouco na instância da audiência, mas na identificação dos procedimentos durante a coleta de dados dos textos que serão comungados pela audiência. Dessa forma, o objeto de interesse seria o conteúdo cultural da notícia, aquilo que é interpretável. Nessa perspectiva, Pan e Kosicki (1999) concluem que frames agem como um dispositivo cognitivo usado na informação, codificação, interpretação e recuperação, podendo-se por meio deles estudar os discursos das notícias e/ou suas características.

Shanto Iyengar (1991: 10) procura diferenciar frames temáticos, que oferecem uma interpretação mais genérica e ampla de uma determinada questão, de frames episódicos, que aplicam uma lente particular a um episódio específico, focando-se em casos individuais e não generalizáveis. Em um frame temático, poder-se-ia tratar mais genericamente dos riscos dos 
organismos transgênicos; já em um frame episódico, a morte da borboleta monarca associada ao milho StarLink poderia ser considerada.

É relevante a distinção de Iyengar (1991) por considerar que cada tipo de enquadramento pode levar a uma atribuição de responsabilidade distinta. A utilização de um frame temático sugere uma contribuição de caráter social, pois são considerados os fatores sociais responsáveis pelo problema, enquanto frames episódicos promovem uma contribuição de carácter individual, atentando-se para a resolução de um problema específico.

Na visão de Mauro Porto (2004: 78), frames operam como “marcos interpretativos sob aspectos mais gerais construído socialmente que permitem às pessoas atribuírem sentidos a eventos e situações sociais". Para ele, a concepção de um enquadramento é resultado de escolhas conscientes feitas pelos repórteres ao angular o texto jornalístico. Nesse processo, há duas espécies de frames: noticiosos e interpretativos. Os primeiros referem-se a padrões de apresentação, seleção e destaque usados por jornalistas para organizar os eventos. Eles podem ser categorizados como episódicos, quando enquadram eventos específicos ou focalizam indivíduos, ou ainda temáticos, enquadrando contextos que extrapolam os fatos. Por sua vez, frames interpretativos têm em sua essência a elaboração feita por atores sociais, promovendo um olhar particular para um problema, a avaliação de causalidades, responsabilidades, propostas, tratamentos e soluções.

Outra alternativa é a proposta por Dietram Scheufele (1999: 109), que diferencia frames individuais de frames de notícia. Os primeiros agem como um complexo cognitivo de esquemas e organização de aspectos da realidade enquanto os segundos se estabelecem no discurso público. Assim, há uma hierarquia entre frames, pois os frames de notícia, já socialmente chancelados, determinariam o modo como os individuais serão interpretados. Essa divisão tem o objetivo prático de guiar o objeto de estudo em uma pesquisa: em estudos de percepção e opinião pública, um pesquisador poderia apelar aos frames individuais, ao passo que estudos interessados na diversidade discursiva e respectivas ações na consagração de um frame, a análise de frames de notícia poderia ser requisitada.

Price et al. (1997) refletiram sobre várias pesquisas que utilizaram frames e identificaram três categorias: conflituosos, de interesse humano e de consequência. Os primeiros são comuns em coberturas para períodos eleitorais, quando a complexidade das pautas se resumem à ênfase no conflito. O segundo apelam às emoções humanas, personificando e dramatizando as notícias. Já o terceiro destaca um evento em relação aos resultados que esse pode vir a desencadear. 
Como levanta Erika Rivers (2009: 27), nos últimos anos especialistas têm caminhado para uma distinção entre frames cognitivos e culturais. Os primeiros se caracterizariam por serem rasos, tácitos, apelando a vícios sociais, presentes em eventos recentes, situacionais e específicos. Já os culturais, também chamados de frames profundos, amplos, estratégicos, interpretativos ou temáticos, seriam facilitadores culturais com papel decisivo na compreensão, e por isso mais abrangentes, generalizáveis, transcendendo histórias imediatas. Nesse sentido, frames culturais auxiliariam uma compreensão mais profunda da temática a que se referem, além de fornecer largo contexto e informações mais fáceis de processar.

Danilo Rothberg (2010: 55), ao revisar importantes autores, propõe que o jornalismo tende a enquadrar os eventos em notícias em cinco tipos de frames: (i) frames de jogos, ocorrem quando os temas mais comuns estão ligados às chances de derrotas ou vitórias, havendo pouco espaço para enfoques mais abrangentes; (ii) estratégicos, quando as ações e decisões dos atores tendem a ser apresentadas como elementos de cálculo e os jornalistas se prontificam a desvendá-las; (iii) episódicos, referem-se aos fatos relevantes do percurso de definição para um tema, acentuando aspectos circunstanciais; (iv) frames de conflito, em que a ênfase recai sobre o potencial de disputa em tese envolvido nos movimentos dos interessados em um questão; por fim, (v) temáticos quando o jornalismo supera a superficialidade dos frames anteriores, trazendo os aspectos concretos envolvidos nas questão de interesse. De acordo com Rothberg (2010), frames temáticos contextualizam os temas de forma plural e equilibrada, relacionando antecedentes e pressupostos, avaliando implicações e examinando alternativas e critérios de comparação. Nas palavras do autor:

\footnotetext{
Uma cobertura centrada em temas exige que os jornalistas saibam situar os diversos aspectos das políticas públicas em seu devido contexto. Eles devem explorar as relações entre antecedentes e consequências segundo diferentes perspectivas, considerando as expectativas das pessoas afetadas e os resultados previstos de acordo com visões diversas (ROTHBERG, 2010: 57).
}

Para Stephen Reese (2001: 11), frames são construções culturais materializadas em discursos públicos que organizam a realidade em termos cognitivos. Primeiro, por seu apelo a tendências psicológicas básicas e, segundo, pois frames encorajam a busca por compreensões culturais antes da retenção da informação básica. Seis características básicas são propostas: (i) organizam informações a gerar significados pela inclusão, exclusão e ênfase de certos aspectos; (ii) baseiam-se em princípios, noções de organização conectadas e concorrentes, pertencentes a uma estrutura social maior; (iii) são essencialmente compartilhados e negociados dentre os atores interessados antes de serem comunicados; (iv) são reutilizados pelo tempo, persistentes 
contra dúvidas que lhes enfraqueceriam; (v) podem ser revelados através de dispositivos simbólicos (e.g., frases, metáforas, argumentos, etc.) e; (vi) promovem padrões identificáveis $a$ priori, não precisam ser introduzidos a todo momento.

Para Robert Entman (1993), uma AF deve contemplar certos elementos que podem ser revelados mediante o exame textual de notícias. Em uma análise próxima a alguns ramos da Linguística, Entman (1993) diz que frames se manifestam por meio de "tijolos linguísticos", isto é, palavras-chave pelas quais seus significados associados poderiam desencadear um frame específico. O autor (1993) sugere que um frame poderia ser decomposto em quatro dimensões: (i) uma dimensão particular à definição de um problema, havendo a descrição dos atores envolvidos e dos subtópicos pertinentes; (ii) um estabelecimento de uma interpretação causal; (iii) uma avaliação moral no tocante a uma definição em termos de justo/injusto, certo/errado, desejável/indesejável, etc. e; (vi) uma recomendação de tratamento, ou seja, é preciso que haja uma atividade intelectiva para deliberar sobre que se deve fazer.

William Gamson e Andre Modigliani (1989: 3) definem o frame de notícia como: "um centralizador de ideias ou narrativas que fornece sentido para uma sequência não reveladas de eventos". Nessa definição, frames de notícia podem "construir significados ao longo do tempo, adicionando novos eventos ao processo de enquadramento interpretativo" (1989: 4), ou seja, se comportam como estruturas embutidas nas reportagens.

Gamson e Modigliani (1989: 3) trazem que frames de notícia podem ser revelados mediante a análise de seus elementos internos. Isso se daria mediante ao que eles denominam "pacotes de frame": um conglomerado de dispositivos lógicos que levam a identificação de certos frames de notícia. Exemplo desses elementos são: slogans, escolha de palavras, metáforas, explicações, argumentos e imagens presentes nas notícias de jornais.

Em síntese, podemos argumentar que as noções de "elementos internos" de Gamson e Modigliani (1989), de "análise de tijolos" de Entman (1993) e de "princípios de organização" de Reese (2001) podem ser utilizados como operadores analíticos capazes de indicar um determinado quadro de notícia. Diante das limitações relativas à conceituação de frames e padronização dos procedimentos metodológicos, técnicas como a de análise de conteúdo e do discurso aparecem como alternativa para a detecção desses operadores. 


\subsection{PROPOSIÇÃO DE UM MODELO PARA FRAMES}

Finalizamos o capítulo apresentando um modelo conceitual que sintetiza a literatura de construção social do risco e de análise de frames (Fig. 1). Nele podemos ver a mobilização dos atores mais legítimos na elaboração de um problema ambiental (e.g., especialistas, cientistas, técnicos, políticos, oficiais do governo, ambientalistas, entre outros). Orientados por seus interesses e visões de mundo, eles agem para enquadrar os problemas ambientais, que por sua vez são materializados em discursos na mídia, os frames de notícia.

Figura 1 - Construção social de quadros de notícia

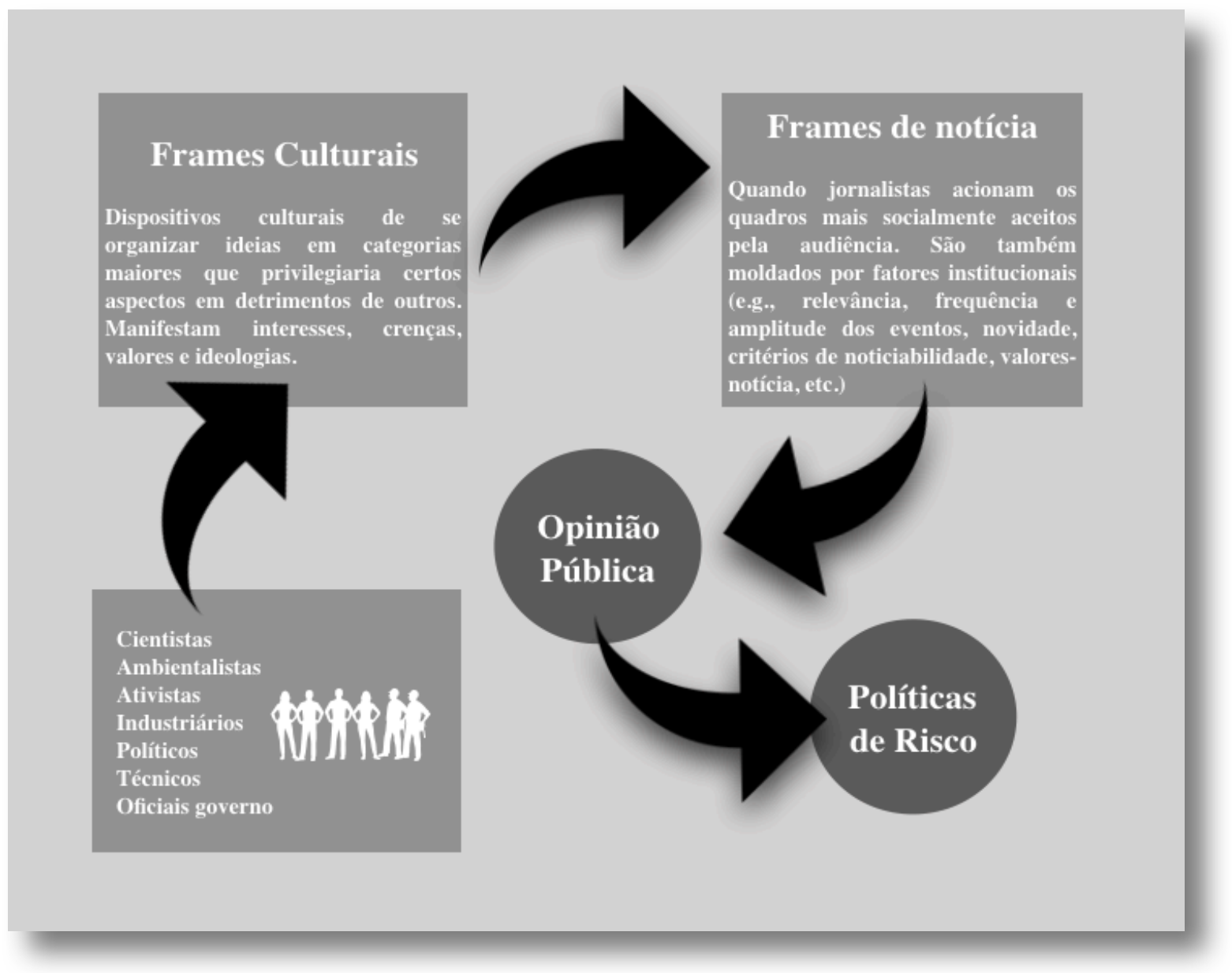

Fonte: elaborado pelo do autor a partir da síntese da literatura.

Em um primeiro momento, esse movimento se dá em um reconhecimento de um problema que até então não era discutido publicamente. Em um segundo, uma vez formuladas, as exigências precisam ganhar legitimidade na agenda. Daí a importância da mídia. Utilizandose da capacidade da mídia de agendar os principais temas discutidos em sociedade, os atores 
interessados se mobilizarão para que seus quadros sejam objetos de reportagem.

Para que um problema penetre na agenda midiática de forma efetiva, as exigências de um problema precisam estar atrativas sob uma perspectiva institucional do jornalismo. Se as notícias possuírem termos muito técnicos e específicos, a maior parte das pessoas não será atingida pela mensagem. Por outro lado, podem ser amplamente compreendidas caso jornalistas se adequam a critérios de noticiabilidade e certos "valores notícia" nos eventos, além de outros fatores, tais como frequência, amplitude da amplificação de um de risco, relevância em termos de proximidade e relação com a vida cotidiana, conformidade com ideias pré-concebidas, etc.

Por fim, logo que exista um quadro dominante sobre a questão, indivíduos começam a esperar, demandar e se mobilizar para políticas de regulação. Frames e frames de notícia, para além de deterem a capacidade de estruturar a vida social, influenciam indivíduos a agirem sob e para determinadas questões enfrentadas coletivamente. Contudo, frames não são eternos, podem ser questionados a cada momento. 


\section{MÍDIA, RISCO E TRANSGÊNICOS}

O termo "risco" designa a combinação entre as chances de ocorrência de certo evento (aleatório, futuro e independente da vontade humana) com seus possíveis desdobramentos não desejáveis. Além das complexas, incertas e contraditórias interpretações envolvidas no enquadramento de problemas ambientais, outra especificidade dos organismos transgênicos se dá pelo fato de seus riscos ambientais estarem fundamentalmente associados a probabilidades acerca de seus impactos. Probabilidades que são socialmente construídas, isto é, são interpretadas, exigidas, negociadas, legitimadas e disseminadas.

De acordo com os autores construcionista, tais probabilidades não emergem fortuitamente nas diversas arenas sociais; são negociadas depois que valores, crenças e opiniões são continuamente ressignificadas entre uma vasta polifonia discursiva. Essa forma de lidar com o risco ambiental rompe com uma tradição quantitativa que o descreve materialmente, mas privilegia o exame daqueles que agem para que seus frames sejam tidos como valor de verdade. Por esse motivo, nenhuma formulação para as ameaças ou oportunidades é correspondente à totalidade material do risco ambiental, tampouco unânime. Muito pelo contrário, qualquer que seja ela, será socialmente construída, portanto, dotada de interesses, opiniões, vícios, vieses, representações sígnicas e ideologias.

\subsection{BREVE COMENTARIO À SOCIEDADE DE RISCO}

Desde o processo de globalização, as civilizações contemporâneas têm encarado situações inéditas de perigos irreversíveis para o planeta causadas exclusivamente pela ação humana. Para Ulrich Beck (1992: 12), que teve ampla produção sobre globalização, modernização ecológica, problemas e riscos ambientais, desigualdades e transformações nas relações de trabalho, a teoria de Sociedade de Risco reflete sobre um momento de transição entre as sociedades industrial e moderna, no qual a humidade não teria alcançado a abundância material, a justiça social e muito menos o controle pleno da natureza. Nessa espécie de continuidade, o homem convive com o paradoxo da modernização: a produção de bem-estar é sempre acompanhada da produção social do risco.

Se desde o início da vida em sociedade a humanidade confiava a resolução de seus problemas em feiticeiros, líderes de religiões animistas ou transcendais, nas sociedades pósindustriais são os especialistas que ocupam esse lugar. Porém, a contínua constatação de que a 
revolução científica não tem garantido o pleno controle dos riscos ambientais contribuiu decisivamente para a percepção coletiva das possíveis consequências que o planeta pode sofrer. Com a autoridade científica repetidamente em cheque, as dúvidas, contradições e incertezas têm se tornado os mais influentes catalisadores para a transformação social. Merryn Ekberg (2007: 02) chega a afirmar que na Sociedade de Risco o conceito de "consciência de classes cedeu lugar à consciência de risco".

É fato que os riscos ambientais vêm à tona pela racionalidade técnico-instrumental, visto que o saber científico é responsável por puxar o gatilho na descoberta de um novo problema ambiental. Entretanto, em uma civilização caracterizada pelas incertezas, complexidades e contradições, a participação de várias clivagens sociais se amplia para definir aquilo que deve ou não ser considerado um risco. Em outras palavras, nas tomadas de decisão sobre como nos relacionaremos com determinado risco ambiental, ainda que os cientistas desempenhem um papel importante, a participação de outros segmentos por vezes é mais determinante. Com maior acessibilidade de informação pela mídia de massa, a participação leiga, por assim dizer, pode ser ainda mais potencializada.

\subsection{A CONSTRUÇÃO SOCIAL DO RISCO}

A literatura construcionista que lida com o risco ambiental tem sinalizado que suas probabilidades são interpretadas, processadas, avaliadas e legitimadas diferentemente a partir das motivações, interesses e ideologias que as várias clivagens sociais têm, além do contexto sociocultural no qual um risco emerge. Diferindo-se de análises tão somente materiais e técnicas, os "construcionistas" levam em conta nas suas investigações outras dimensões qualitativas do risco, tais como eventos não esperados, diferenças entre espaço, população e tempo, além dos custos sociais, culturais, políticos e humanos (DI GIULIO, 2012: 235), o que traz à luz perspectivas singulares para se lidar e compreender os diversos grupos sociais que se mobilizam frente a problemas ambientais.

Para William Solesbury (1976: 382), o alerta de grupos organizados para um determinado risco configura uma condição necessária, mas não suficiente para que um problema ambiental tenha sua existência reconhecida. Antes disso, o risco precisa ser chancelado socialmente nas várias arenas de debate, sobretudo na imprensa, na comunidade científica e nas instâncias do poder público. No entanto, mesmo que um risco seja avaliado como legítimo, não é assegurado que uma ação de sua mitigação ou resolução seja tomada. Por 
essa razão, os grupos interessados necessitam agir para que a questão seja inserida e discutida dentro de uma agenda pública, convertendo-se de fato em leis e regulações.

Para a antropóloga Mary Douglas e o cientista político Aaron Wildavsky (1982), quaisquer agrupamentos sociais poderiam ser classificados em três arranjos elementares: individualistas, hierárquicos e igualitários. Os primeiros se preocupariam com as dinâmicas dos mercados; os segundos, com a burocracia governamental e as formas de poder; os terceiros com a participação pública e o meio ambiente. Douglas e Wildavsky (1982) notaram que as formulações das percepções de um risco variavam consideravelmente através desses três arranjos, repercutindo no modo pelo qual a seleção das chances de risco é trazida à tona. Dito de outro modo, os aspectos sobre os quais grupos consideram acerca do risco seriam baseados muito menos na profundidade das evidências científicas e chances de um evento negativo ocorrer que nas vozes que predominam em sua avaliação.

Paul Slovic (1987: 283) atenta para o papel da cultura na determinação de um risco, pois ele somente é apreendido quando culturalmente contextualizado. Em razão disso, quaisquer definições de risco devem ser compreendidas essencialmente como construções sociais. Isto é, devemos trata-las conforme uma dialética entre atores que visam atribuir significação às probabilidades do risco, com raízes psicológicas, institucionais e sociais. Além disso, o autor percebeu que a aceitação ou a rejeição de determinados riscos está relacionada aos seus potenciais catastróficos, ainda que a probabilidade de ocorrência seja excepcionalmente baixa. Dito de outro modo, mesmo eventos ambientais com baixa probabilidade de ocorrer - porém com consequências extremas - podem ser percebidos como mais ameaçadores do que aqueles que têm consequências mais moderadas e comuns.

Da mesma maneira, Karl Dake (1992: 27), aluno orientado por Wildavsky, vê a cultura como uma das principais variáveis na construção de um risco. Ao defini-la como um sistema de crenças internalizadas pelos indivíduos de um grupo, ela deteria a capacidade de moldar as ideologias que influenciam as interpretações dos fenômenos naturais. Sendo assim, para se compreender um risco seria muito mais proveitoso apreciar os processos históricos, sociais e de aculturação pelos quais os indivíduos foram submetidos do que simplesmente analisar as justificativas objetivas que empregam em suas concepções. Por exemplo, Di Giulio (2012) ao examinar quatro casos de contaminação por chumbo - três no Brasil e um no Uruguai, notou distintas mobilizações, estratégias e ações sociais dentre aqueles que se perceberam como mais vulneráveis nessas situações de perigo. 
Próxima das proposições de Dake (1992), Slovic (1987), e Douglas e Wildavsky (1982), a geógrafa francesa Yvette Veyret (2007: 23) afirma que qualquer risco sempre se refere a uma construção social porque se trata fundamentalmente de uma percepção promovida pelos atores participantes nos contextos em que os problemas se definem. Assim, "o risco, objeto social, se define como a percepção de um perigo, da catástrofe possível (...) é a tradução de uma ameaça, de um perigo para aquele que lhe é submetido e o percebe como tal" (VEYRET, 2007: 11).

A autora avalia que esse processo não varia só de uma cultura para outra, mas também entre diferentes "campos sociais" tais como o econômico, o político, o da engenharia genética, etc. Por isso que para Veyret (2007: 11), o risco deve ser tratado como objeto social, ou seja, como uma percepção de perigo possível, apreendido por representações mentais e práticas sociais específicas que são constrangidas pelos contextos que o cria.

Ortwin Renn (2008), embora não fale sobre "campo social”, mas em "arenas sociais", atenta que é preciso capturar a complexidade na construção de um risco, pois o termo "contexto sociocultural" se mostra um tanto vago. O autor diz que muitos dos "construcionistas" falham no detalhamento dos fatores estruturais que moldam as interações entre grupos sociais e isso influencia o resultado dos conflitos sobre o risco. Diante disso, Renn (2008) propõe um aprofundamento maior nesses aspectos, usando uma noção de arena multinível, na qual os atores que se percebem como mais vulneráveis apresentam maior probabilidade de engajamento. As várias interações e estratégias adotadas entre atores, em níveis micro, meso e macro da arena, determinariam o reconhecimento de um risco.

Hannigan (2006: 99) afirma que riscos ambientais são reconhecidos amplamente quando certo grupo social começa a observar situações de risco como problemas ambientais. E vai além: a fim de explicar a emergência de riscos ambientais, bastaria ater-se a três pontos essenciais: (i) a essência do risco; (ii) a forma como ele é tipificado e; (iii) os argumentos dos atores para a persuasão social. O autor (2006: 116), tal como Renn (2008), parte de que os riscos se constituem por meio de um processo de construção pública em que há conflitos técnicos e políticos contextualizados em uma arena. Nela, seis papéis sociais se destacam:

Portadores de risco: as vítimas que arcam diretamente com os custos dos riscos. Pelo avanço das noções coletivas de justiça ambiental no mundo, esse grupo de maior vulnerabilidade tem ampliado sua participação nos processos decisórios;

Advogados dos portadores: indivíduos mais socialmente articulados que buscam visibilidade para os direitos dos mais vulneráveis aos riscos; 
Geradores de risco: corporações químicas e farmacêuticas, silviculturas e indústrias em geral que são rotuladas como antagonistas pelos advogados dos portadores;

Pesquisadores do risco: atores da comunidade científica que têm competência para colher evidências e legitimar o risco;

Árbitros: são os mediadores, que determinam os níveis aceitáveis de risco;

Informadores do risco: nas sociedades contemporâneas são os meios de comunicação em massa. Assumem os papéis de amplificadores das informações de risco.

Robert Stallings (1990: 81) procura determinar não apenas quem são os atores sociais que participam da criação, seleção e distribuição dos riscos, mas também dos mecanismos nos quais os riscos são disseminados e quais os processos em que os riscos são construídos. $\mathrm{O}$ autor destaca a importância da mídia na seleção dos eventos a serem reportados, das entrevistas e dos comentários, e dos especialistas auxiliam as pessoas na interpretação dos eventos naturais. Caso um risco seja rejeitado, aceito ou modificado, os pareceres pelos especialistas sobre sua definição servem como pontos de partida para conversas pessoais que circulam na sociedade, potencializando o ciclo das ideias dominantes.

Em síntese, os construcionistas notaram que as vozes valem muito mais na avaliação de um risco do que ele mesmo em sua realidade material. Dessa forma, a elaboração do risco é entendida como intrínseca aos contextos socioculturais, arenas e campos em que os atores reivindicam suas concepções preferidas. Sem embargo, ainda que os atores ligados à ciência possam apresentar maior poder de influência na construção de um risco, atores com menor legitimidade, se mais persuasivos e "jogando" melhor de acordo com as regras de determinado campo ou arena, podem vir a desempenhar um papel mais determinante. A mídia, como amplificadora do risco, agendadora das grandes questões coletivas e influente na opinião pública, ganha destaque especial nessa dinâmica. De fato, há quem a declare a arena mais relevante (GAMSON et al., 1992). A próxima seção traz um debate das formas como construcionistas têm visto o papel dos meios de comunicação

\subsection{O RISCO SEGUNDO A MÍDIA}

À vista de que a ação humana poderia causar impactos irreversíveis nos ecossistemas planetários, cresce nas últimas quatro décadas o interesse público pela questão ambiental (ANDERSON, 1997; BECK, 1992; COX \& DEPOE, 2015; HANNIGAN, 2006; LESTER, 
2010). Para Hannigan (2006), somente depois dos anos 1990, após a ocorrência de vários desastres ambientais, ao mesmo tempo em que há uma maior conscientização coletiva dos impactos provocados pelo homem e o aparecimento de convenções internacionais a exemplo da Rio-92 e da comissão Nosso Futuro Comum (1987), que a grande imprensa passou a incluir em sua agenda a temática do meio ambiente.

Pelas notícias de rádio, televisão, jornais e portais da internet, a audiência tem acompanhado o surgimento de diversos movimentos ativistas, grupos de cientistas e partidos políticos alertando para os riscos ambientais, e.g., as mudanças climáticas, redução da biodiversidade, poluição dos ecossistemas e contaminações gerais, catástrofes nucleares e os perigos da transgenia. Em oposição, também se observa uma espécie de "antítese discursiva", quando é dado espaço na mídia para grandes corporações transacionais que refutam as evidências do aquecimento global (BOYKOFF, 2014), ou ainda quando a agroindústria comunica que a biotecnologia é livre de riscos (PRIEST, 1994).

Nesse cenário de incertezas, não demorou muito para que as adjacências entre comunicação, jornalismo, meio ambiente e risco se consolidassem como objeto de estudo acadêmico. Grosso modo, o interesse de pesquisa nas representações do ambiente tem como espinha dorsal as relações do homem com a natureza (COX \& DEPOE, 2015: 15) e, especialmente, com o conhecimento e a participação nas políticas ambientais. Porém, como observa Anderson (1997), a mídia de massa segue a investigação e a revelação dos acontecimentos como um observador grosseiro na cobertura dos riscos ambientais. Como já discutido, ela precisa limitar os possíveis quadros para os eventos de risco, ato que implica em uma redução significativa da complexidade que rege a natureza.

Em desastres ambientais, por exemplo, a cobertura dá prioridade para a recuperação das várias formas de capital, baseados em vieses culturais e sociais presentes na mídia (MILES \& MORSE, 2006: 365). E são justamente tais prioridades que moldam como as percepções de risco influenciam o conjunto de estratégias para mitigações de futuras vulnerabilidades que o público leigo julga racionais, lógicas e objetivas. Assim, compreender as lutas simbólicas contínuas e as ações sociais direcionadas para a definição dos riscos ambientais está no núcleo vital do estudo da comunicação ambiental. Nesse sentido, o meio ambiente é tido como uma preocupação em movimentos permanentes nas esferas sociais, culturais e políticas.

Mark Miller e Parnell Riechert (2000) caracterizam o potencial de um risco tornar-se notícia segundo seus "valores notícia", já discutidos no capítulo anterior, na seção sobre newsmaking. Quanto mais valores notícia, tais como, proximidade, impacto na vida cotidiana, 
potencial destrutivo, dramatização narrativa do conflito, entre outros, observa-se uma maior probabilidade de jornalistas noticiarem e/ou enfatizarem o evento. Os autores (2000) também verificaram que para riscos ambientais os "valores notícia" geralmente são relacionados com algum tipo de conflito que envolva atores com interesses, motivações e interpretações de risco singulares como tomadores de decisão.

De modo muito parecido à Miller e Riechert (2000) e às proposições do newsmaking, Giancarlo Sturloni (2006) identificou os seguintes critérios de noticiabilidade que são explorados em situações de risco: (i) pluralidade de elementos na natureza: que inclui a proximidade do risco bem como a violação de normas de conduta que contribuiria para sua manifestação; (ii) dramatização da narrativa: referente à presença de vítimas identificadas, atribuição de culpa, dualidade entre bons e maus e a existência de um conflito e; (iii) técnica: quando há disponibilidade de imaginação, isto é, a inserção de um contexto pré-existente (STURLONI, 2006 apud DI GIULIO, 2012).

Di Giulio et al. (2008) e Di Giulio (2012), que estudaram mídia e comunicação para situações de contaminação de solo, notaram que riscos ambientais são enquadrados pela mídia quase sempre como frutos de um acontecimento específico. Ao invés de resultados decorrentes de decisões essencialmente políticas, eles costumam ser tratados como problemas dissociados de processos históricos, sociais e econômicos. Além disso, Di Giulio et al. (2008) aponta que a pauta "risco" por si só tem a tendência de capturar a atenção da mídia. Contudo, as noções de risco são noticiadas de variadas formas, dando voz a cientistas, ambientalistas, políticos, entre outros atores, que frequentemente têm concepções opostas. Atuando assim, é de se esperar que a cobertura para os riscos favoreça o noticiamento de eventos mais dramáticos em detrimento de outros mais ordinários.

Mas não basta educação para que o público leigo compreenda os pontos levantados pela ciência na mídia, pois como observaram Botero e Babrow (2013), pessoas não iniciadas podem não se alinhar tão rapidamente com o posicionamento de especialistas. Em situações em que há muita diversidade de porta-vozes participando das discussões sobre problemas ambientais e riscos, pesquisas apontam que na grande audiência há mais ignorância e confusão (STOCKING, HOLSTEIN, 2009). Ademais, é crescente o número de atores disseminando incertezas, contribuindo para a ignorância dos leigos (RYAN, 2014).

Por último, a mídia também frequentemente é concebida como uma "estação amplificadora de risco". A metáfora para "amplificação" é explicada pelas teóricas clássicas da 
comunicação, nas quais há a descrição dos processos de intensificação ou atenuação de sinais durante a transmissão de uma mensagem.

Para Roger Kasperson (1992), a mídia detém o poder de popularizar as informações para indivíduos e grupos que tendem a processá-las e agir sobre as mesmas. Isso ocorre uma vez que os impactos de um risco são explicados pela combinação dos efeitos materiais desse evento com os processos psicológicos, institucionais, sociais e culturais, abraçando a comunicação científica, a mídia, grupos diversos e redes interpessoais. Assim:

\footnotetext{
O processo de amplificação de risco, como nós o concebemos, se inicia ou em um evento físico (por exemplo, um acidente) ou o relato sobre eventos ambientais ou tecnológicos, lançamentos, exposições ou consequências. Alguns grupos e indivíduos também, certamente, procuram por ameaças relacionadas com sua agenda de preocupação. Em ambos casos, indivíduos ou grupos selecionam características específicas desses eventos ou aspectos de descrição associados. Eles da mesma forma comunicam suas interpretações para outros indivíduos e grupos e recebem interpretações de volta. Grupos sociais e indivíduos processam a informação, localizam-na em sua agenda de preocupações e podem se sentirem compelidos a responder " (KASPERSON, 1992: 159).
}

Portanto, de acordo com Kasperson (1992), a maior parte das informações sobre certo risco é advinda de fontes secundárias, principalmente pelos meios de comunicação. Assim, as diversas interpretações de risco são processadas, interpretadas e até mesmo ressignificadas nas várias estações de amplificação.

\subsection{TRANSGÊNICOS COMO UMA PAUTA MIDIÁTICA}

Se há a possibilidade de um debate esclarecedor sobre transgênicos, ciência, ética e política, ele depende em grande medida dos meios de comunicação. A audiência leiga, como um todo, tem outras preocupações que não as técnicas em seu cotidiano. Por mais que possa vir a se envolver e interessar por alguns aspectos, pesquisas empíricas mostram que ela tem à sua disposição informações simplificadas e facilmente esclarecidas (BAUER et al., 2001; BROSSARD \& SHANAHAN, 2007; PRIEST, 1994; ROTHBERG, BERBEL, 2010).

Por essas razões, é muito mais provável que a mídia detenha maior poder de influência para os transgênicos do que para questões mais ordinárias da vida cotidiana. Apesar de maior poder de influência não promover necessariamente manipulação direta, como proposto pela 
teoria de "agulha hipodérmica", a mídia influencia o clima das opiniões, moldando o curso dos debates. Mais que isso, análogo à teoria de "espiral do silêncio", quadros completamente contrários aos dominantes não teriam espaço na sociedade.

Na hipótese de um dia haver consenso sobre a inexistência de riscos em relação aos transgênicos, será um absurdo algum porta-voz reivindicá-lo. Dessa forma, a imprensa teria, de certa forma, a habilidade de afetar a cognição de indivíduos, bem como estruturar seu pensamento. Navarro et al. (2007), por exemplo, observaram que quando a mídia ignora partes negativas de uma certa tecnologia o suficiente para que sejam lembradas só as positivas, verifica-se maior probabilidade do público leigo aceitá-la.

É por isso que Susanna Priest (1994: 41) insiste na ideia de equidade de informações. A despeito da legitimidade de especialistas quando opinam sobre biotecnologia, a mídia deveria ater-se mais a questões políticas e impactos sociais (PRIEST, 1994: 42). Desse modo, haveria mais espaço para posições que consideram os interesses das pessoas leigas.

Priest (1999) traz a metáfora da avaliação das informações de biotecnologia como a compra de um carro usado:

\begin{abstract}
Para não cientistas, avaliar informações científicas (tais como dados incertos senão riscos prováveis) há muito em comum ao comprar um carro usado. Como consumidores cuidadosos, nós precisamos contar com informações técnicas e sociais. Achamos que é importante ter dados técnicos para a quilometragem, histórico de donos e uso, idade, performance do motor, condições mecânicas e assim por diante. Nós também queremos informações sociais, e.g., o tipo de reputação do vendedor, o fabricante, marcas e modelos específicos, quem são os vendedores e porque querem vender (por exemplo, por que eles poderiam estar ansiosos). Em suma, queremos saber se alguma informação está oculta (PRIEST, 1999: 95).
\end{abstract}

A autora deseja demonstrar que quanto menos confortáveis sob os aspectos técnicos da biotecnologia, maior a tendência de avalição pelos critérios sociais. Se em uma temática não há unanimidade suficientemente clara, a mídia é frequentemente forçada a escolher dentre especialistas antagônicos dada a falta de clareza técnica (PRIEST, 1999: 96). Ora, em função da dificuldade em se lidar com um tema tão complexo como a biotecnologia, seria interessante

\footnotetext{
${ }^{5}$ Segundo a teoria de "agulha hipodérmica", uma mensagem emitida pela mídia seria imediatamente aceita entre todos os receptores, em igual proporção, implicando manipulação. Muito utilizada para analisar propagandas nazistas, seu uso atual é descartado dentre especialistas.

${ }^{6}$ Segundo a teoria de "espiral do silêncio", as pessoas que detêm opiniões confrontantes às opiniões dominantes tendem a omiti-las de seus pares devido ao medo de sofrer isolamento social.
} 
se a mídia desse espaço a atores que trouxessem situações concretas e hipotéticas detalhando os impactos causados em diferentes cenários com o advento da liberação dos transgênicos.

Para Baruch Fishhoff (2013), a educação fornece a base para os elos entre comunicação e biotecnologia: quanto mais um indivíduo possui domínio sobre um campo do conhecimento (Biologia, Botânica, Agricultura, Genética, Ética, Economia e Política), melhor preparado está para compreender os processos de regulação envoltos à biotecnologia agrícola. Portanto, a sua cobertura precisa investigar quanto o conhecimento científico já existente é capaz de abordar e explicar os problemas práticos da vida cotidiana. Se as informações são eruditas demais, tendem a não capturar a atenção das pessoas, encorajando a mídia a ignorá-las. Contudo, caso focalizem o cerne das informações que repercutem na vida cotidiana, talvez a mídia possa qualificar a audiência para os processos regulatórios.

Camille Ryan (2014), uma autora pró-biotecnologia, lista cinco fatores-chave que dirigem a opinião pública acerca dos transgênicos: (i) a relação não familiar das audiências com a ciência; (ii) hábitos cognitivos e percepção de risco; (iii) o papel das redes sociais pessoais que influenciam opiniões, atitudes e comportamentos; (iv) o amplo uso de plataformas de redes sociais e; (v) a proliferação de falsos especialistas ou celebridades despreparadas atuantes contrariamente aos transgênicos. Para Ryan (2014), a pior faceta da mídia consiste em ser um espaço dominado por uma série de vozes (ativistas e ambientalistas) sem o devido embasamento científico devido, com discursos que escapam à realidade.

A despeito dos posicionamentos antagônicos, lutas simbólicas e mobilização de grupos interessados para a atribuição de sentidos aos transgênicos, o assunto compõe um tema cujas deliberações coletivas de seu uso repercutem na vida cotidiana de todos. Mudanças repentinas nos sistemas agrícolas poderiam ser sentidas por toda a sociedade a cada safra. Para complicar, seus conceitos não são familiarizados à maioria das pessoas, dotada de jargões técnicos, pesquisas e notícias que se contradizem a todo momento. Alguns autores atribuem tanta importância ao estudo de sua cobertura que a consideram a terceira tecnologia mais importante desde o período pós-guerra, depois da Energia Termonuclear e das Tecnologias de Informação (DURANT et al, 1998; MAESEELE, 2007).

Dominique Brossard e James Shanahan (2007: 4) revisaram e sistematizaram uma série de estudos empíricos sobre biotecnologia agrícola e comunicações de massa, chegando que elas podem ser compreendidas segundo a investigação de quatro componentes: (i) conhecimento, (ii) confiança, (iii) discurso mediado e (iv) comunicação de risco (Tab. 3): 
Tabela 3 - Biotecnologia Agrícola e Mídia

\begin{tabular}{ll} 
Componentes & \multicolumn{1}{c}{ Descrição } \\
\hline \multirow{3}{*}{ Conhecimento } & $\begin{array}{l}\text { Embora assumido no senso-comum que quanto maior o conhecimento técnico } \\
\text { da biotecnologia agrícola, maior será sua aceitação pelo público, estudos } \\
\text { empíricos não conseguem observar tal relação. Tal fato indica que outras vozes } \\
\text { que não as científicas podem ser mais determinantes em sua aceitação }\end{array}$ \\
\hline A princípio, trata-se de como uma forte atitude fomentada pelos contextos \\
culturais e educacionais; em seguida, tende a ser uma atitude mais volátil, com \\
maior probabilidade de ser impactada pela cobertura de eventos específicos
\end{tabular}

Fonte: adaptado de Brossard e Shanahan (2007)

Há quem trate a biotecnologia como um exemplo de "movimento social da tecnologia" (BAUER, 2002), pois deve ser vista como um objeto de tensão contínua (Fig. 2). Em primeiro, a biotecnologia precisa ser promovida por alguma instituição formal, sendo a mídia a principal divulgadora da ciência. Em segundo, as projeções de futuro percebido e argumentos lógicos sobre a biotecnologia podem mais ou menos determinar seu apoio pela sociedade. Em terceiro, haverá reações em “ondas sociais” em torno do que é aceito. Essas ondas não são homogêneas, abrindo caminho para que haja disputas internas por objetivos conflitantes. Em quarto, os atores dessas ondas encontram arenas públicas, onde eles tentam persuadir sobre seus entendimentos. Por fim, a biotecnologia não se trata de um único movimento, mas se caracteriza pela luta entre vários atores, que pode ser alterada a qualquer momento.

As várias ondas sociais, portanto, influenciam ao longo do tempo as diferentes formas como a biotecnologia será enquadrada pela mídia (BAUER et al., 2001). Durant et al. (1998), Dahinden (2002) e Nisbet e Lewenstein (2002) notaram que na década de 1970 a revolução biotecnológica capturava o ideal de progresso. Nesse momento, houve grande mobilização de cientistas e governos realçando os benefícios da tecnologia. Fato que mudou substancialmente em 1990, quando "caixa de Pandora" indicava ondas para o risco, dirigidas por grupos antiglobalização que viam nas patentes um projeto de expansão neoliberal no mundo. 
Figura 2 - Heurística para compreensão de movimentos tecnológicos

\section{Opinião Pública}

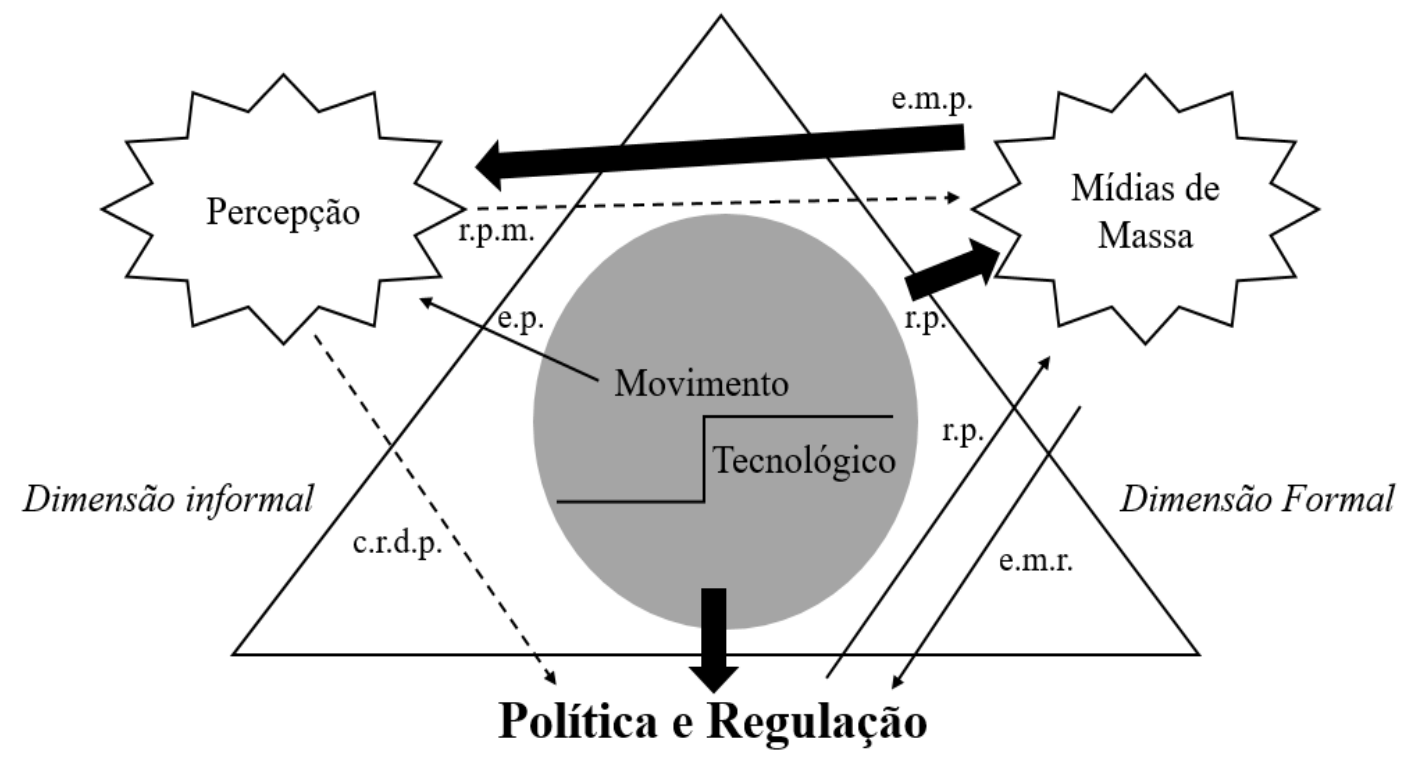

O movimento tecnológico é cercado por três arenas da esfera pública: política e regulação, conversas informais e a mídia. Ocorrem as seguintes relações: (e.m.p.) efeitos midiáticos na percepção pública; (r.p.) relações com o público; (e.m.r) efeitos da mídia nas regulações; (c.r.d.p.) contatos relativamente diretos com o público (e.g., discussões públicas); (e.p.) educação pública.

Fonte: adaptado de Bauer (2002: 150).

Baseados nas considerações feitas por Downs (1972), Nisbet e Huge (2006) observaram os frames nos jornais The New York Times e Washington Post desde as primeiras menções à tecnologia, em 1978, até o final de 2004. Os autores evidenciaram que os frames variam nas mídias conforme a familiarização do problema à audiência, dependendo do estágio em que se encontram no ciclo, manifestam-se de modo mais dramático ou mais técnico. Parece razoável que as seções de opiniões figurem dentre os frames mais dramáticos e sensacionalistas, capturando maior atenção pública, ao passo que frames mais técnicos e específicos são encontrados quando especialistas dominam a cobertura, tornando as notícias com critérios de noticiabilidade menos atraentes.

\subsection{PESQUISAS EMPÍRICAS QUE EMPREGARAM A TIPOLOGIA}

No capítulo anterior, discutiu-se que Gamson e Modigliani (1989), com base em uma orientação de frames culturais, propuseram uma tipologia com o objetivo era extrair os "elementos internos" das notícias de jornal para que pudessem codifica-las em frames de notícia. $\mathrm{O}$ método criado por eles era originalmente destinado à cobertura de energia nuclear, mas foi amplamente utilizado em pesquisas de cobertura midiática em biotecnologia em 
diversos países. Essas pesquisas mostram que, desde a introdução do tema biotecnologia nos anos 70, a mídia o enquadrava com certo entusiasmo, o que explicava a supremacia do frame "progresso". Contudo, com o passar das décadas, houve declínio desse enquadramento, enquanto "responsabilidade pública", por outro lado, começou a se consolidar (Fig. 3). Não obstante, o aumento generalizado de "caixa de Pandora" também indica o surgimento dos riscos relacionados à biotecnologia como problema ambiental.

Figura 3 - Achados de frames de notícia para biotecnologia

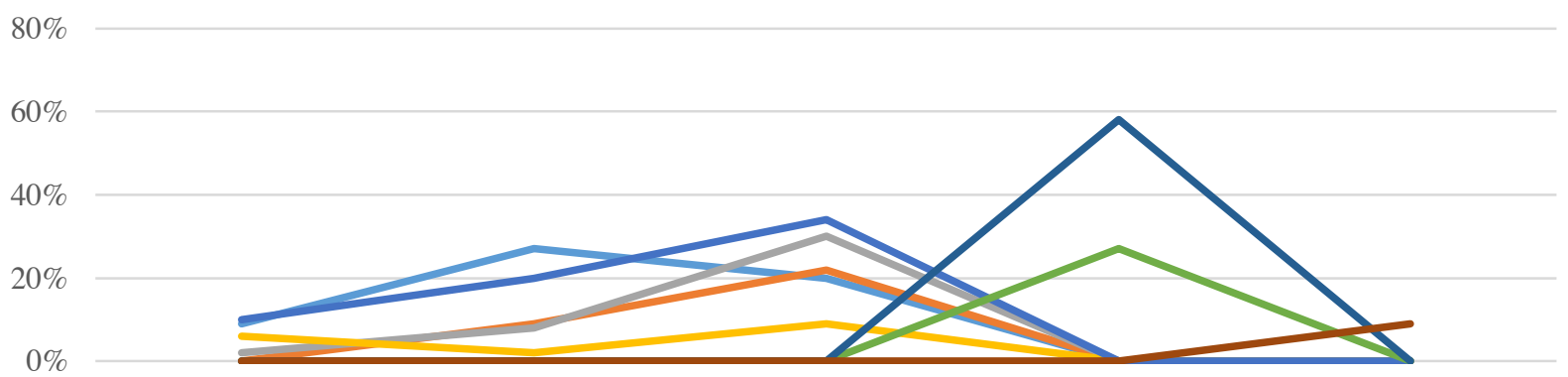

Responsabilidade Pública
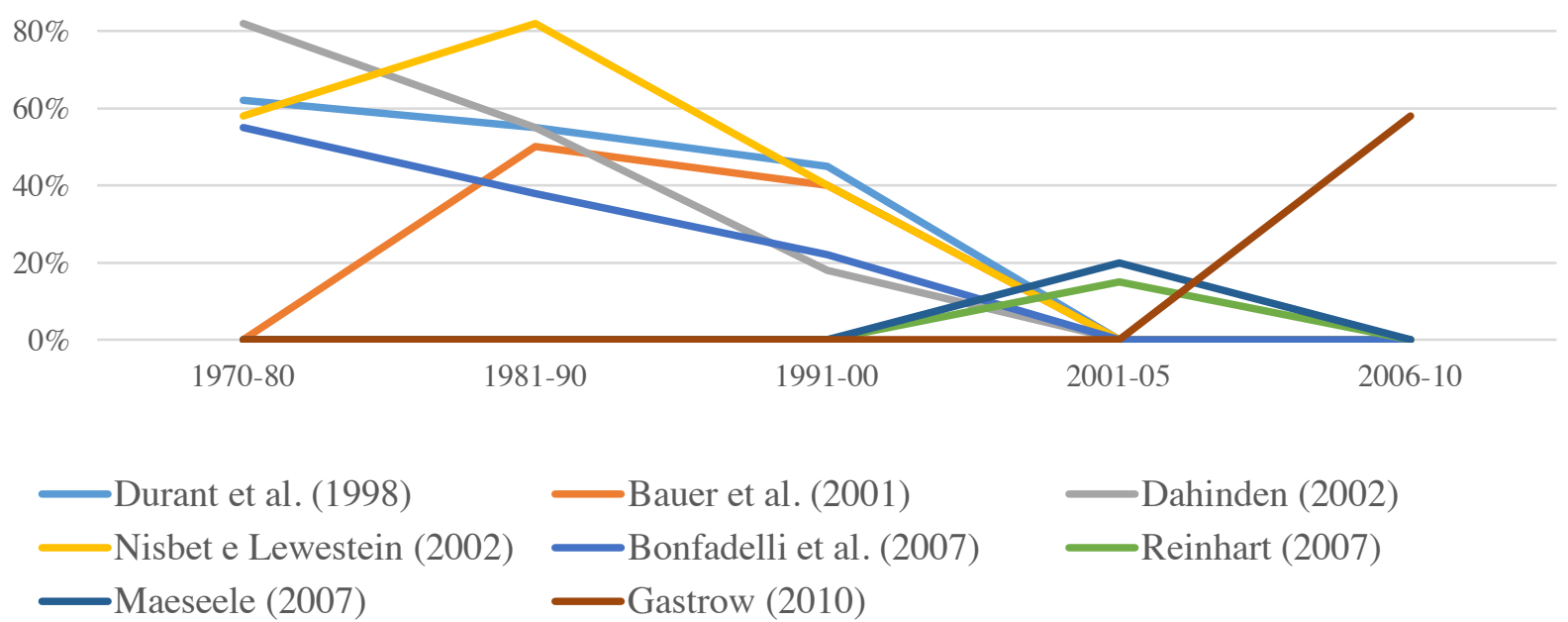

Fonte: sistematizado pelo autor por meio da revisão bibliográfica.

Na Áustria a supremacia de "progresso" era clara, dominando 85\% do enquadramento midiático. A Finlândia teve "progresso" como frame predominante no período de 1973-91, embora "econômica" e "responsabilidade pública" tenham apresentado forte crescimento nos últimos anos desse recorte. De modo semelhante, na França "progresso" e "econômica" foram predominantes, ainda que no período de 1992-94 o frame "ética" tenha apresentado a segunda maior frequência (20\%). Na Alemanha também houve supremacia do frame "progresso", sendo que de 1985-91 "responsabilidade pública" demonstrou forte crescimento (22\%) - semelhante à cobertura italiana - mas de 1986-91 o segundo frame mais presente foi "ética" (17\%) e na 
francesa, o frame "responsabilidade pública" chegou a $28 \%$ de 1982-87. Na contramão dos resultados da UE, na Dinamarca o frame mais frequente era o de "descontrole" (35\%), que alcançou $50 \%$ de $1984-86$ e $42 \%$ de $1987-91$.

Bauer et al. (2001), continuando os trabalhos de Durant, Bauer e Gaskell, analisaram distintos jornais de referência da União Europeia, dividida a pesquisa em dois recortes temporais: de 1992 a 1996 e de 1997 a 1999. Os resultados mostram que na "primeira onda" $50 \%$ dos frames foram enquadrados como "progresso", seguido por "prospecto econômico" (17\%), “ética" (12\%) e "reponsabilidade pública" (10\%). Já na "segunda onda", houve expressiva queda de "progresso" (42\%), embora continuasse o frame predominante, e houve aumento significativo de "participação pública", com 16\% dos frames, o segundo mais frequente. Os demais quadros mantiveram-se relativamente estáveis.

Na Suíça, Urs Dahinden (2002) promoveu a análise de frames da cobertura midiática justificando que, embora o debate tenha sido marcado por conflitos e polêmica, assim como na União Europeia, as mídias suíças não sofreram influências estimuladas por eventos externos e internacionais (e.g., o clone Dolly, a importação de soja transgênica, etc.). Ao contrário, por eventos internos e relativos ao desenvolvimento nacional. Observando o período que vai de 1980 a 2000, o autor constatou radical redução do quadro "progresso" ao longo do tempo, de aproximadamente $80 \%$ na década de 70 para aproximadamente $30 \%$ no período julho de 1998 a 2000. Além disso, o frame "responsabilidade pública", com frequência inexpressiva até meados dos anos 80, apresentou forte presença, desde a década de 90 , com mais de $30 \%$ dos enquadramentos, passou a figurar o principal frame de notícia.

Bonfadelli et al. (2007) também analisaram a biotecnologia no país. Com foco na diferenciação entre "biotecnologia verde" e "biotecnologia vermelha", contextualizaram as características atípicas desse país em função de seus mecanismos de democracia direta. Embora com amostra distinta da de Dahinden (2002), que observou a cobertura de 1973 a 2002, os resultados foram semelhantes no tocante à mudança da predominância do frame "progresso" para "responsabilidade pública". Comparada com a "biotecnologia vermelha", a pesquisa revelou que a "biotecnologia verde" costuma ser mais controversa, menos relacionada aos progressos sociais e à saúde. Ainda, mostrou que a "verde" apresentou mais enquadramentos relacionados a regulação e impasses políticos.

Matthew Nisbet e Bruce Lewenstein (2002) examinaram a cobertura do jornal The New York Times e a revista Newsweek no período de 1970 a 1999, alegando a ausência de um estudo com grande recorte temporal desse tipo de estudo nos EUA. Seus achados foram levemente 
diferentes dos estudos anteriores: embora a hegemonia de "progresso" tenha se consolidado no período de 1970 a 1989 (de 58\% para 82\%), de 1995-99 houve redução próxima da metade (39\%). A partir de meados de 90, "ética" teve notável crescimento, ocupando o segundo lugar (22\%). Uma das explicações para o aumento de "ética" pode estar no fato de que de 1995-99 mais de $67 \%$ dos arquivos tratavam de temas relativos a clonagem animal e humana.

Hannah Reinhart (2007), ao analisar editoriais e cartas ao editor do jornal St. Louis PostDispatch no período de 1997 a 2006, constatou que o frame "responsabilidade pública" foi predominante, com teor de controvérsia frequentemente reportado, ainda que posições radicais foram raras. Devemos ressaltar, porém, que a amostra considerou apenas as seções mencionadas, o que limitou muito a generalização do estudo. Não obstante, o jornal St. Louis Post-Dispatch não é considerado referência, podendo ser mais enviesado para o debate político, o que talvez explicaria os resultados.

Na Bélgica, Pieter Maeseele (2007) empregou a tipologia às mídias da maior região de seu país no período de 2000 a 2004, justificando que as pesquisas de Durant, Bauer e Gaskell (1998) não examinaram a cobertura belga e que além disso na primeira metade dos anos 2000 novas ações sociais passaram a surgir após os Years of Watershed. A pesquisa encontrou "responsabilidade pública" como frame absoluto (60\%), seguido por "caixa de Pandora", com cerca de $20 \%$ e "progresso" com pouco mais de $10 \%$. O estudo consolidou a tendência observada nos demais países europeus de que há, atualmente, maior preocupação do público em relação à regulação da biotecnologia verde.

Michael Gastrow (2010) aplicou a mesma tipologia para a cobertura na África do Sul, analisando os anos de 2005 a 2010 de distintos jornais de referência. Diferente das outras pesquisas, onde observávamos mais ou menos uma tendência de encontrar em um primeiro momento a supremacia de "progresso" e com o passar do tempo a consolidação de "responsabilidade pública", os dados de Gastrow mostraram a frequência de 56\% para "progresso", seguido de "ética" (24\%) e "prospecto econômico" (12\%).

\subsection{TRANSGÊNICOS NA IMPRENSA BRASILEIRA}

A retratação dos transgênicos na grande mídia brasileira foi razoavelmente bem abordada por distintas áreas. Antes de pretender comparar abordagens tão díspares entre si, acreditamos que a síntese desses estudos possa render bons padrões de comparação para análise e discussão de nossos resultados. De modo geral, os estudos constaram grande polarização entre defensores 
e opositores, matriz geradora dos conflitos nas mídias. Alguns autores identificaram picos de controvérsias no que se refere à introdução e o processo de regulação, ao passo que outros detalharam melhor as representações sígnicas para transgênicos. Em comum, ora o progresso é exaltado, ora os riscos imperam, ora os embates políticos na regulação.

Antônio Herbelê (2005), em sua tese de doutorado suportada na semiótica pragmática de Pierce, observou o funcionamento semiótico do conceito de "transgênicos" operacionalizado pelos principais jornais impressos do Rio Grande do Sul. Em sua pesquisa, que teve o recorte de 1995 a 2002, pôde extrair os efeitos de produção de sentido do tema pela mídia, que variaram entre "impacto positivo", "solução avançada", "sustentação econômica", "social”, "medo, ameaça, problema", “impacto negativo", "agressão à natureza", “incerteza, dúvida", “possibilidade de ser algo", "necessidade de dados" e "esclarecimento do que trata".

Renata Menasche (2005) igualmente teve como objeto a imprensa gaúcha. A autora aponta para a falta de consenso multifacetada em diversas áreas (Ciência, Política, Religião, Economia, Meio Ambiente, Saúde, etc.) e que envolve mais que aspectos científicos, mas também econômicos, sociais, ambientais, sanitários e, especialmente, políticos. O recorte escolhido, de 1999 a 2003. A partir da contextualização de diversos conflitos políticos locais, Menasche (2005) destaca o trabalho da mídia na amplificação desses, que tende a reproduzir as representações sociais existentes antes do ato jornalístico de produção de notícias. Em virtude da complexidade da temática e divergências entre atores, a mídia não pode fornecer um debate longe das controvérsias como principal critério de noticiabilidade dos acontecimentos relacionados aos transgênicos.

Um terceiro trabalho para a imprensa do Rio Grande do Sul foi realizado por Fernanda Petrarca (2005). Examinando alguns periódicos do estado do Rio Grande do Sul, identificou três principais argumentos que marcaram a cobertura: (i) argumento polêmico, que exaltava as controvérsias; (ii) argumento da fiscalização, com as mídias reportando as atividades dos agentes da administração pública visando ao cumprimento das exigências legais e; (iii) o argumento dos riscos, referentes à proximidade ou iminência de ameaças.

Flavia Medeiros (2007) realizou uma análise de conteúdo e de frames sobre transgênicos nos periódicos O Globo, Jornal do Brasil e Folha de São Paulo, observando alguns frames presentes nesses periódicos nos anos de 1999 e 2000. Apesar de seu interesse estar em analisar as diferenças entre os cadernos de "Ciência" com a cobertura geral, seus resultados empíricos corroboram com outras pesquisas brasileiras no tocante ao predomínio de frames científicos (e.g., avanços das técnicas, anúncio de descobertas, decisões sobre pesquisa e desenvolvimento, 
etc.) e frames normativos (e.g., as disputas judiciais, discussões legais e normas sobre produtos transgênicos, etc.). De acordo com seus achados, o frame cientifico foi predominante na Folha de São Paulo. Já no Jornal do Brasil houve predomínio do frame normativo. Por fim, O Globo apresentou em 1999 o frame científico como mais frequente, não havendo diferença em 2000 com o frame normativo.

Allain et al. (2009) analisou os jornais Folha de S. Paulo e Estado de S. Paulo, de 2000 a 2005. O conteúdo divulgado sobre os transgênicos no país poderia ser dividido em duas categorias: a primeira referente às discussões da introdução dos transgênicos e a segunda à regulação. $\mathrm{Na}$ introdução, a cobertura que contemplou os aspectos econômicos teve considerável espaço nesses jornais, ao passo que a regulamentação recebeu menor atenção. Já no processo de regulação, as notícias concentraram-se no assunto com base na Lei da Biossegurança. Em suma, a pesquisa mostrou que houve inicialmente pouca discussão sobre os possíveis riscos da biotecnologia, conduzindo o debate mais na direção dos benefícios econômicos e o progresso que os transgênicos proporcionam.

Danilo Rothberg e Danilo Berbel (2010), a fim de avaliar a pluralidade das informações sobre organismos transgênicos oferecidas pelos jornais Folha de S. Paulo e O Estado de S. Paulo, analisaram os principais frames de notícia no período de 2005 a 2007. Os autores verificaram que, por um lado, os jornais oferecem quadros que caracterizam os transgênicos como produto do avanço tecnológico, dotados de benéficos para a economia e capazes de solucionar problemas complexos como a fome mundial; por outro, mas em menor proporção, podem trazer riscos potenciais à biodiversidade e à saúde humana. Sobre diferenças no enquadramento entre jornais, O Estado apresentou mais frames que contribuíram para uma agenda favorável em relação a Folha.

Com objetivo inicial de encontrar achados semelhantes aos de Nisbet e Huge (2006) com base no modelo de ciclos de atenção de Downs (1972), Brossard et al. (2013) encontraram nos seus resultados o que definiram como "ano da controvérsia", quando identificaram, em 2003, um pico intenso de debate público e político sobre alimentos transgênicos. Os autores não conseguiram encontrar nesse período o ciclo. Apesar disso, utilizando-se de uma tipologia de frames diferente da desta pesquisa, os quadros predominantes eram relacionados a política e conflitos nos periódicos $O$ Globo e Folha de S. Paulo, justamente no período que antecedeu a regulação dos transgênicos pela Lei da Biossegurança (Lei 11.105/2005). 


\section{RESULTADOS}

\subsection{CARACTERÍSRICAS DA AMOSTRA}

O portal Estadão Digital concentrou a maior parte das notícias 57\% (792 ocorrências) contra 43\% (604) da Folha de S. Paulo, totalizando 1.396 artigos:

Figura 4 - Distribuições gerais

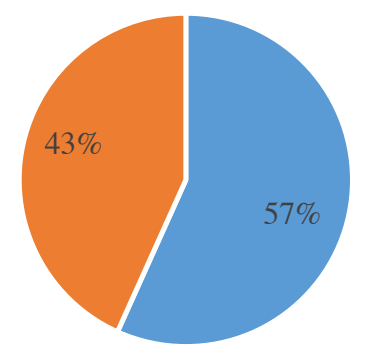

• Estadão Digital — Folha/UOL

Fonte: elaborado pelo autor a partir dos dados

Quanto à distribuição das notícias por ano, há um crescimento acentuado da cobertura em 2003, com valores mantidos altos em 2004. No ano subsequente, presencia-se uma queda brusca que estabiliza a distribuição:

Figura 5 - Distribuição de notícias por ano

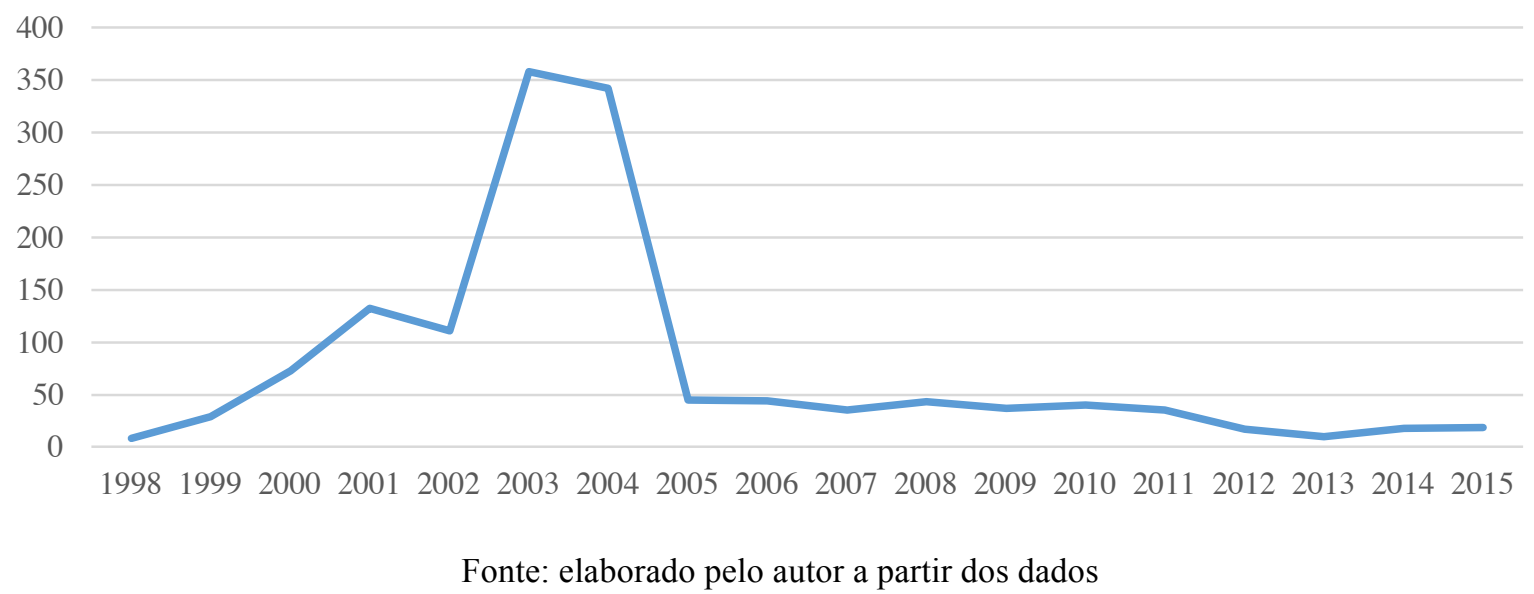

Encontramos 41 seções distintas em ambos jornais, evidenciando certa falta de padrão dos periódicos digitais na classificação do assunto. A seção mais frequente foi "Ciência", com 455 menções (33\%), seguida por "Mercado" 255 (18\%), "Economia" 212 (15\%), "Política" 190 (14\%), “Geral” 56 (4\%), “Opinião" 43 (3\%), “Internacional” 24 (2\%), "Poder” 18 (1,3\%) e demais seções somavam 143 ocorrências (10\%). 


\subsection{FRAMES NO PERÍODO}

Em todo o período, de 1998 a 2015 (Fig. 6), "responsabilidade pública" foi o quadro absoluto, com 802 notícias (57\%). Ocupando a segunda posição, "globalização" deteve 170 (12\%), muito próximo a "caixa de Pandora" 168 (12\%) e "progresso" 150 (11\%). "Prospecto econômico" reuniu 78 artigos (6\%). Demais frames foram inexpressivos.

Figura 6 - Frequência relativa de frames de 1998 a 2015

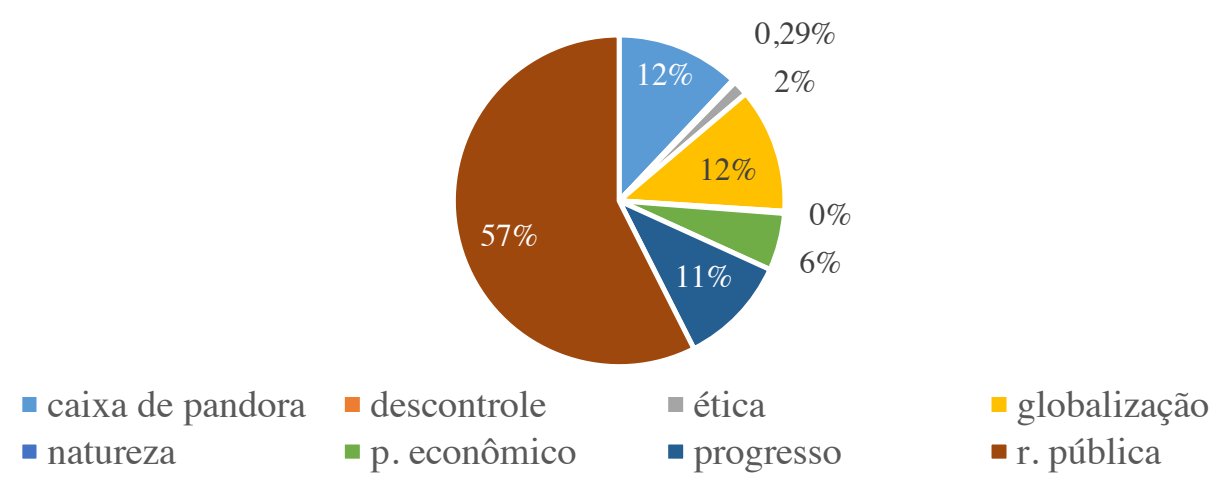

Fonte: elaborado pelo autor a partir dos dados

Na série histórica de frames em valores absolutos (Fig. 7), é nítida a supremacia de "responsabilidade pública" nos primeiros onze anos.

Figura 7 - Distribuição de frames por ano

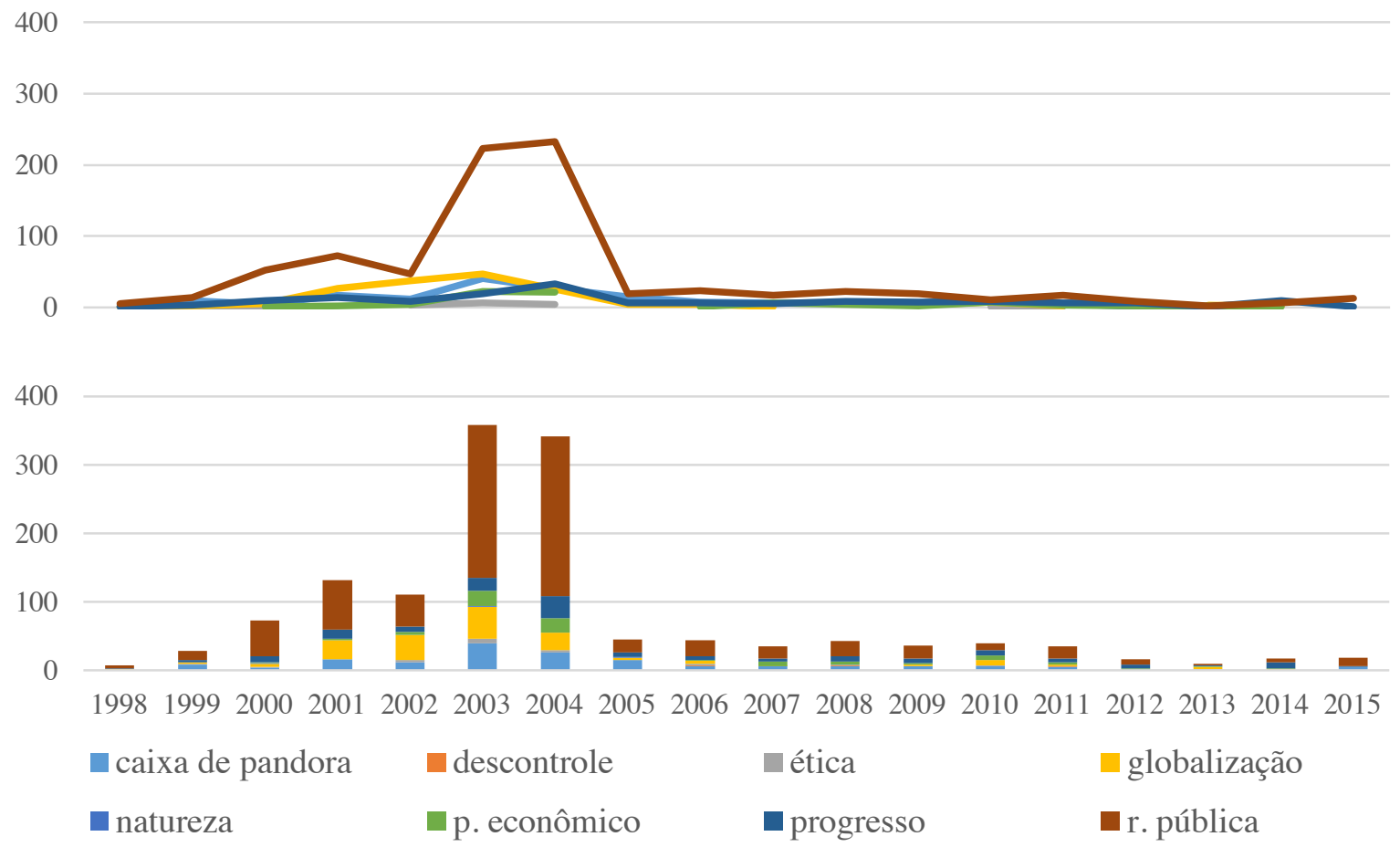

Fonte: elaborado pelo autor a partir dos dados 
Chama atenção especialmente os altos índices em 2003/04, cuja concentração de "responsabilidade pública" deteve 456 observações (56\% de todos os frames). Quando analisamos a série de frequência relativa (porcentagens) dos frames (Fig. 8), também se percebe a concentração de notícias enquadradas em "responsabilidade pública":

Figura 8 - Frequência relativa de frames por ano

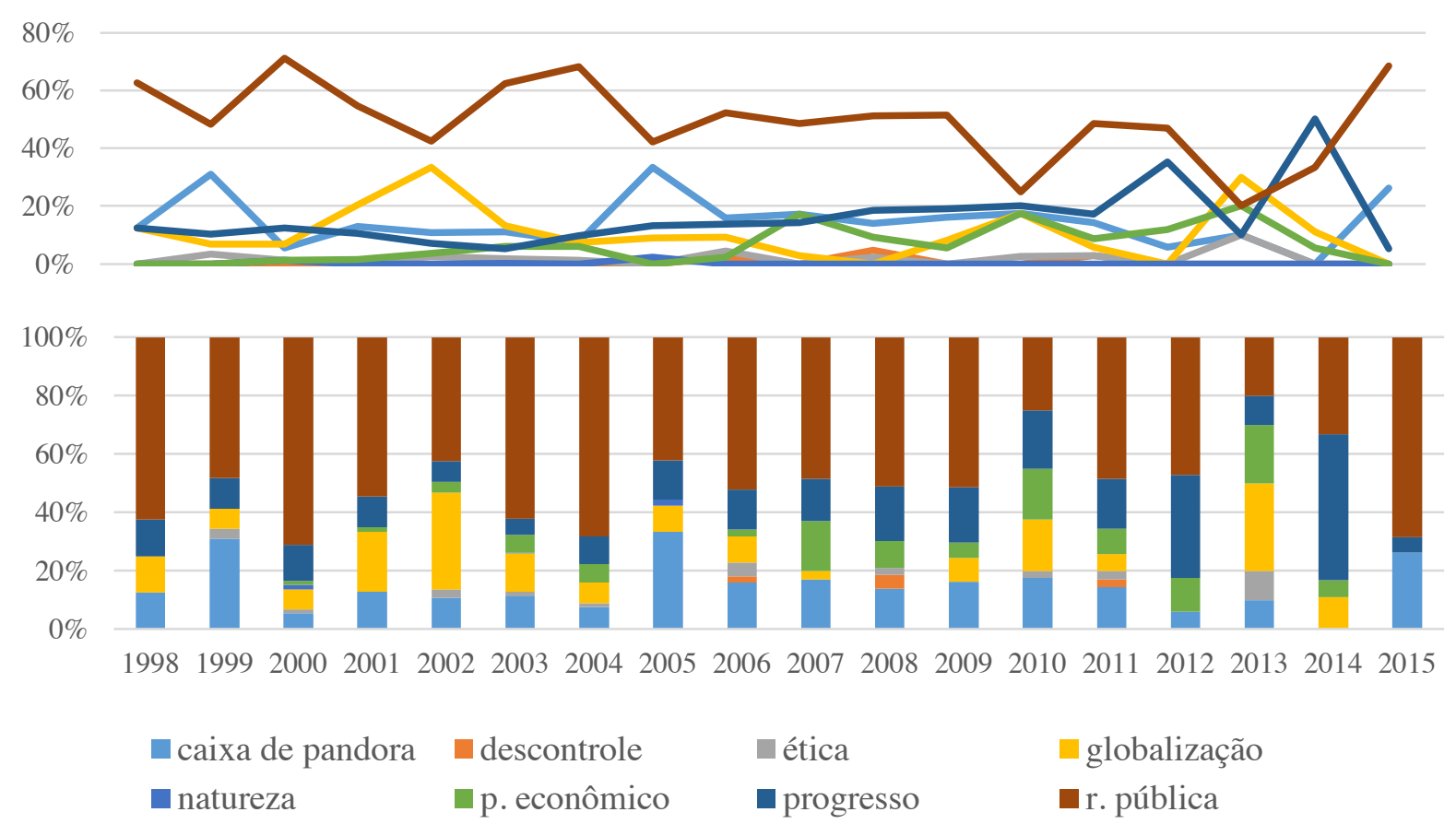

Fonte: elaborado pelo autor a partir dos dados.

\subsection{DIFERENÇAS ENTRE JORNAIS}

A figura 9 traz uma comparação entre os portais em seus enquadramentos:

Figura 9 - Diferenças entre jornais

Estadão Digital

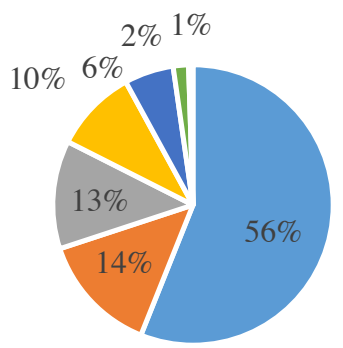

- r. pública

caixa de pandora globalização

- p. econômico

- descontrole
Folha de S. Paulo/UOL

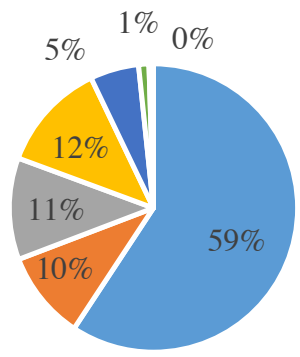
- r. pública
- globalização
- caixa de pandora
- p. econômico
- progresso
- natureza 
Para "responsabilidade pública", o periódico ESPD apresentou 56\% (444 observações) contra 59\% (358) da FSP;

“Globalização" é o segundo quadro mais abordado pelo ESPD, com 14\% (110), mas somente o terceiro dos enquadramentos na FSP, representando $10 \%(60)$;

Por outro lado, "progresso" demonstrou maior participação relativa na Folha, com 12\% (74), enquanto no Estado esse valor foi de 10\% (76);

"Caixa de Pandora" deteve 13\% (99) no ESPD, enquanto na FSP 11\% (69);

Por último, "prospecto econômico" obteve 6\% (45) no Estado e 5\% (33) na Folha. Os demais quadros apresentaram valores não significativos. Se observamos mais detalhadamente as séries históricas, algumas diferenças são mais salientes:

Figura 10 - Enquadramento dos jornais

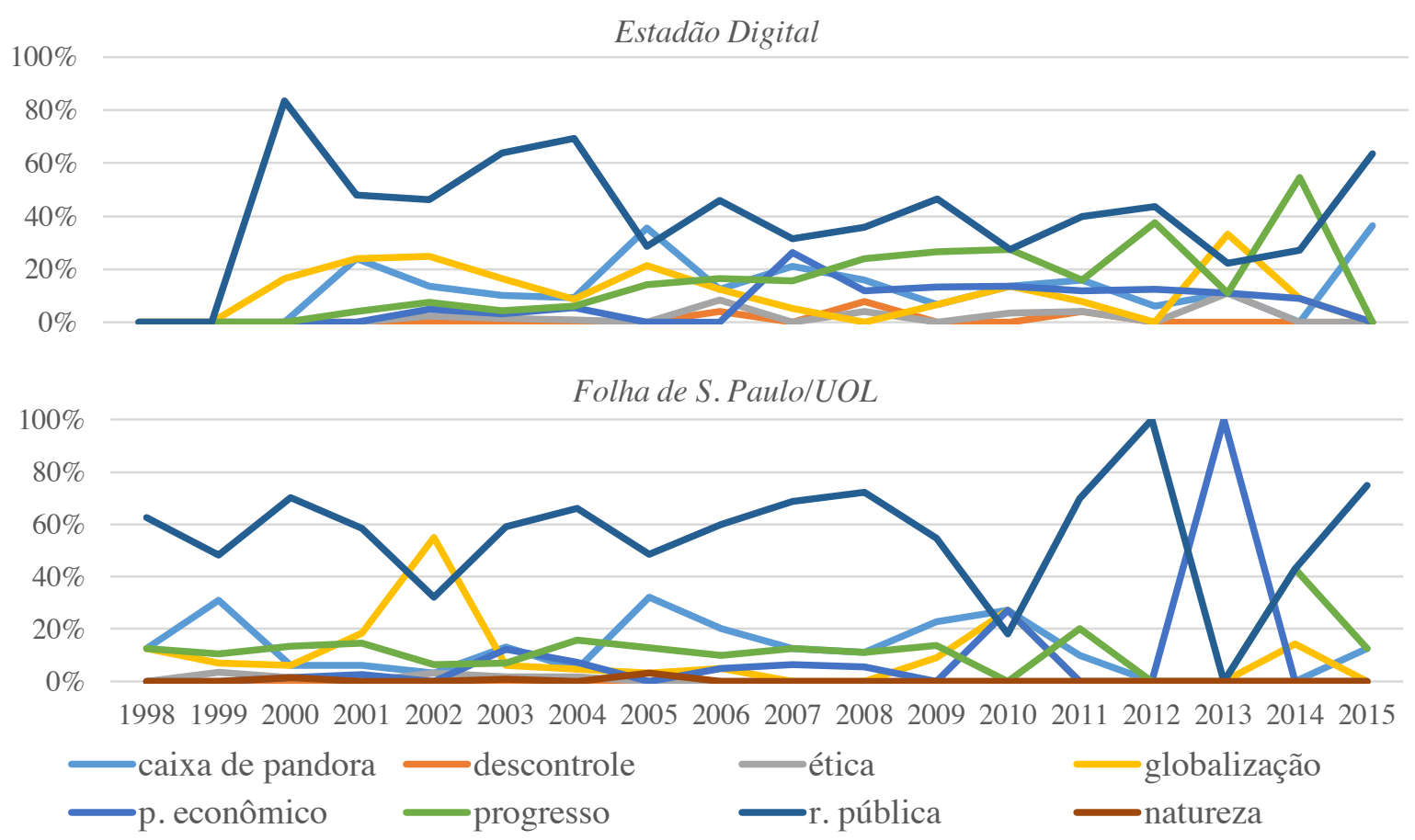

Fonte: elaborado pelo autor a partir dos dados

No ESPD, a hegemonia de "responsabilidade pública" se deu em 2000/04, sofrendo uma queda gradual. Já na FSP, esse frame se comporta de modo mais homogêneo, ainda que no período de 2009/11 sofra grande instabilidade. "Globalização" ocorreu mais uniformemente nos primeiros anos no portal ESPD, enquanto em FSP foi mais instável. "Progresso" ainda apresenta um crescimento consistente no Estado, padrão não observado na Folha. 


\subsection{SUPREMACIA E QUEDA EM "RESPONSABILIDADE PÚBLICA"}

A despeito de algumas variações, na frequência relativa de "responsabilidade pública", podemos observar uma queda sútil com a passagem do tempo:

Figura 11 - Frequência relativa de "responsabilidade pública"

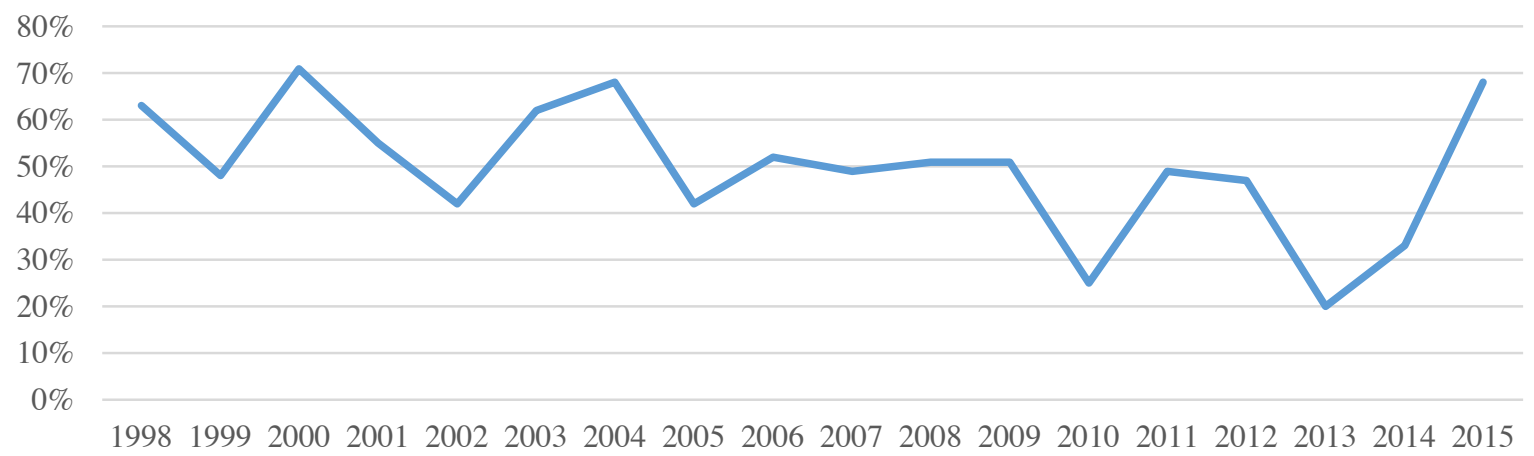

Fonte: elaborado pelo autor a partir dos dados

No período de 1998 a 2004, houve pico de $71 \%$ em 2000 e ponto mínimo de 42\% em 2002. De 2005 a 2014, o ponto máximo alcançou 52\% (2006) e mínimo de 25\% (2010). A média de "responsabilidade pública" foi de 45 notícias/ano, apresentando desvio padrão de 67. O alto índice de variabilidade expressa a concentração nos anos 2003/04, que apresentaram a quantidade de 456 artigos (56\%). O próximo gráfico apresenta as porcentagens de temas em "responsabilidade pública":

Figura 12 - Frequência relativa de temas em "responsabilidade pública"

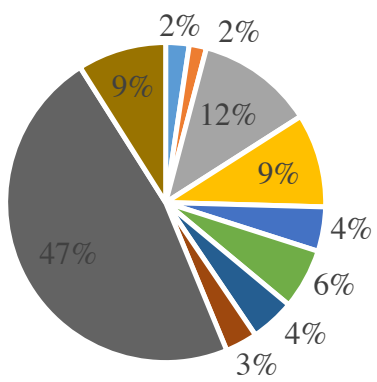

\footnotetext{
- avanço dos transgênicos

conflito

- informação sobre produtos com transgênicos

- pesquisa

- regulação

- chamada para participação pública

- fiscalização

- outras

protesto

rotulagem
}

Fonte: elaborado pelo autor a partir dos dados 
"Regulação" detém aproximadamente metade (379 observações) de todos os temas; “conflito" obteve 12\% (95); "fiscalização" deteve 9\% (76); "rotulagem" apresentou 9\% (72) e demais temas somaram $23 \%$ (180 observações).

"Regulação" reúne as notícias referentes ao processo de edição, tramitação e sanção de leis, de medidas provisórias ou das deliberações e portarias emitidas pela CNTBio com força de lei. Também inclui a judicialização da matéria quando não havia legislação específica.

"Conflito" reporta disputas e visões contraditórias entre defensores e opositores, seja pela falta de consenso entre especialistas e fontes que têm espaço para se pronunciarem.

"Fiscalização" engloba as reportagens que tratavam da atuação de órgãos oficiais de fisscalização (MPF, PF, Justiça, agências reguladoras, etc.).

"Rotulagem" concentra os artigos que pautavam conflitos específicos acerca dos rótulos dos transgênicos, endurecimento ou afrouxamento de leis a respeito.

A figura 13 apresenta a série história dos temas encontrados em "responsabilidade pública" em valores absolutos e percentuais. Notamos, aqui, a maior parte das ocorrências em "regulação" entre 2003/04, que representava cerca de 70\% de todas notícias.

Figura 13 - Temas em "responsabilidade pública"

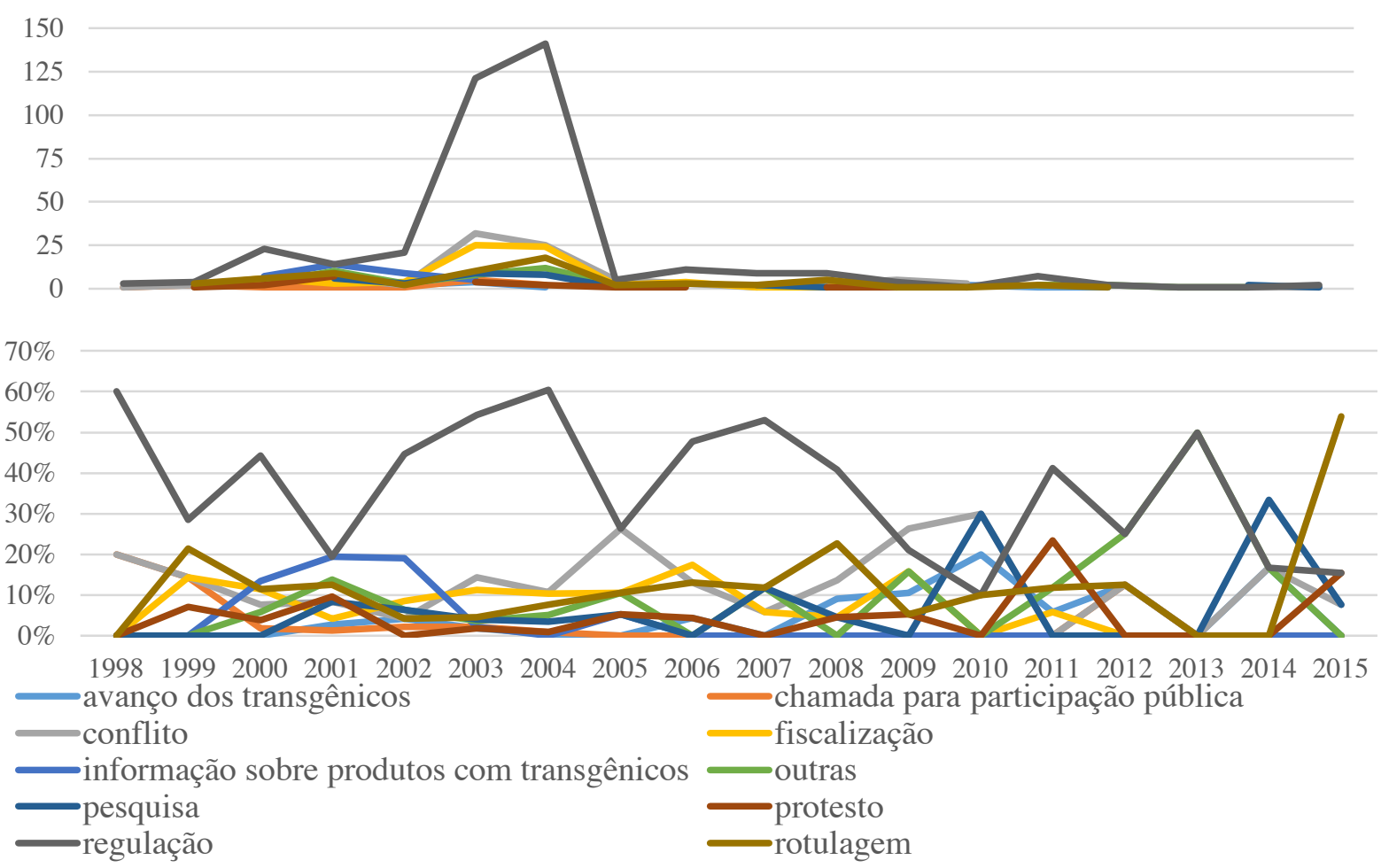

Fonte: elaborado pelo autor a partir dos dados. 


\subsection{QUEDA EM “GLOBALIZAÇÃO”}

Embora haja forte instabilidade na distribuição da frequência relativa de "globalização" (Fig. 14), há uma tendência para queda se compararmos o período de 1998 a 2003 com 2004/12. Os anos de 2002 e 2013 foram atípicos, com valores de 33\% e 30\% respectivamente. A média de quadros foi de 11 notícias/ano, com desvio padrão de 14. O índice expressa a concentração de notícias no triênio 2002/04, com 47, 45 e 45 notícias respectivamente.

Figura 14 - Frequência relativa de "globalização" por ano

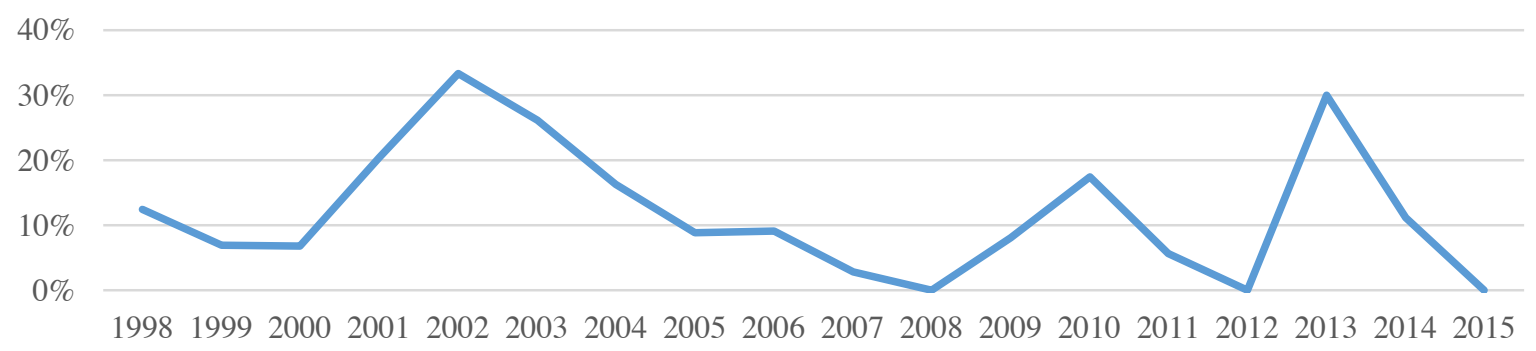

Fonte: elaborado pelo autor a partir dos dados.

Quanto à frequência relativa dos temas (Fig. 15), "conflito" teve 35\% (59 ocorrências), seguido por "protesto" 20\% (34), "regulação" 17\% (29), “cooperação internacional” 24\% (24), outras 9\% (16) e "oportunidades de desenvolvimento" 4\% (7).

Figura 15 - Temas em "globalização"

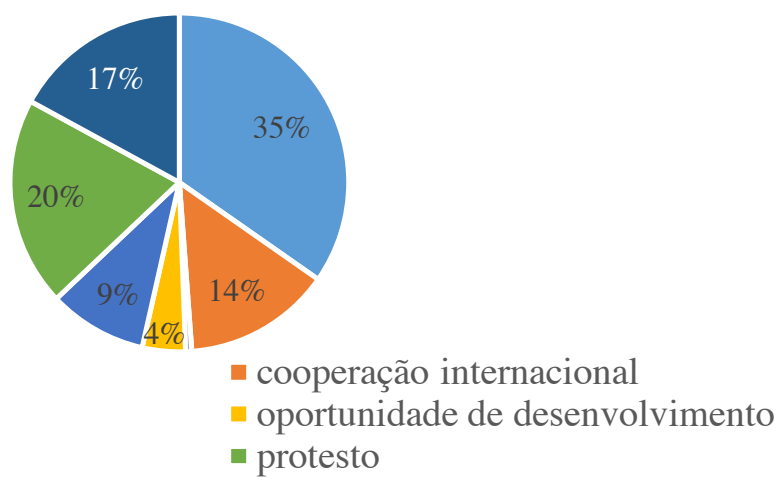

Fonte: elaborado pelo autor a partir dos dados

"Conflito" é a categoria que reúne as reportagens com disputas em contexto internacional, em grandes convenções mundiais em que nações se posicionam diferentemente.

"Protesto" apresenta notícias sobre a mobilização de organizações globais contra os transgênicos e a atuação antiglobalização de ativistas conhecidos mundialmente. 
“Cooperação internacional” centraliza os acordos de cooperação econômica entre nações, de forma a disseminar globalmente a biotecnologia e transgênicos.

"Regulação" trata da regulação dos transgênicos em diferentes nações, com exceção do Brasil. O próximo histograma traz a distribuição temas/ano em termos absolutos:

Figura 16 - Temas em "globalização"

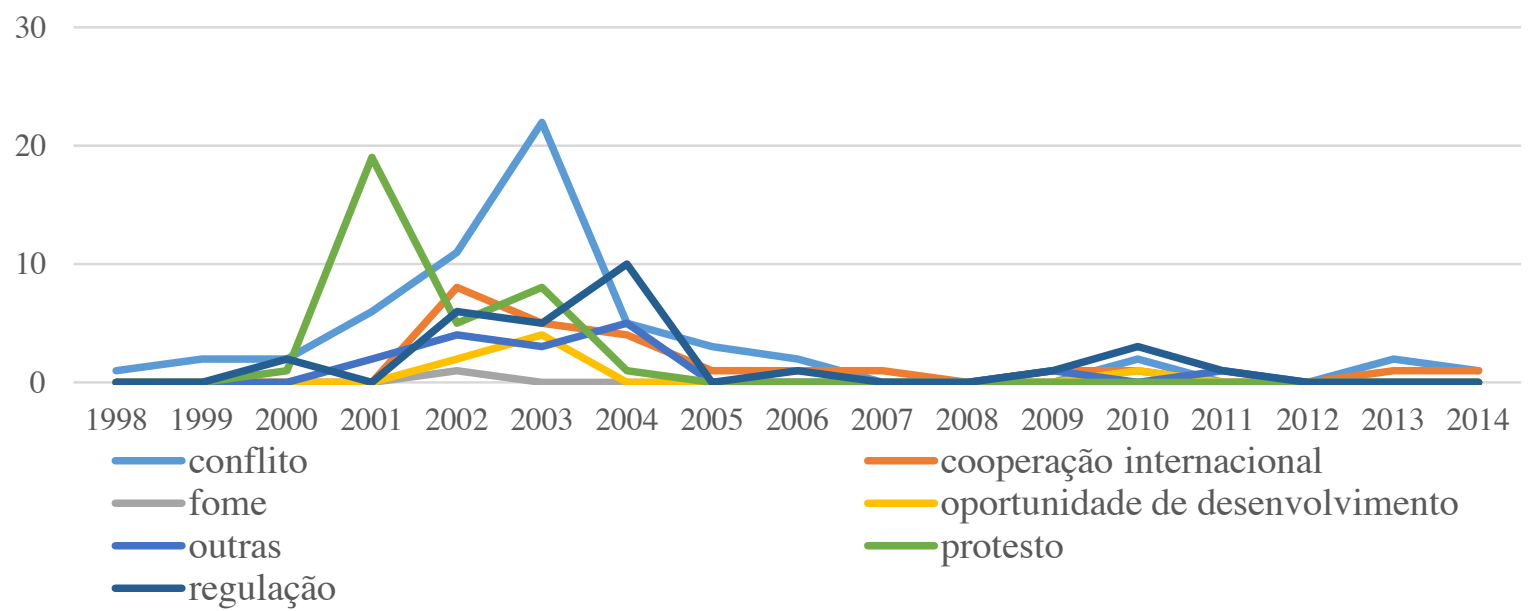

Fonte: elaborado pelo autor a partir dos dados

"Globalização" apresenta mais notícias nos anos de 2001 e 2003, destacando-se entre elas os temas "conflito" e "protesto" nos primeiros anos (de 1998 a 2003). "Cooperação internacional" passa a ser mais presente entre 2007/11. À exceção de "responsabilidade pública" os temas nos demais frames não ocorrem em grandes massas de dados, deixando os histogramas sensíveis a pequenas variações. Por isso não são apresentados.

\subsection{INSTABILIDADE EM "CAIXA DE PANDORA"}

A próxima figura apresenta a série de frequência relativa de "caixa de Pandora".

Figura 17 - Frequência relativa de "caixa de Pandora" por ano

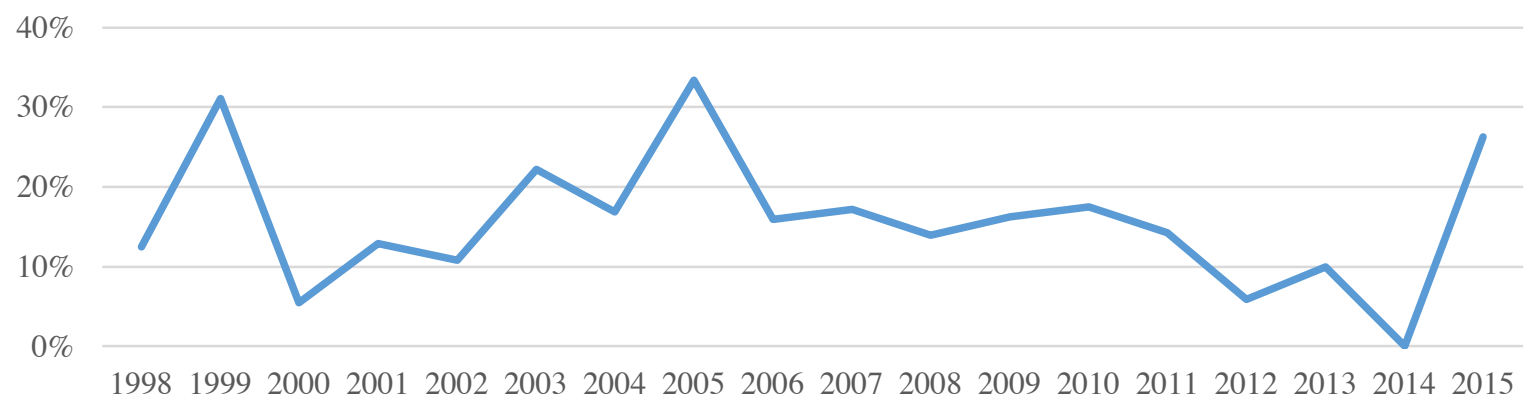

Fonte: elaborado pelo autor a partir dos dados 
Podemos ver uma distribuição irregular, com pontos mais altos em 1999 (24\%) e 2005 (24\%). Dentre os pontos mais baixos, há 2004 (7\%), 2013 (5\%) e 2014 (3\%). A média de quadros é de 9 notícias/ano, com desvio padrão de 9. Diferentemente de outros frames, a variabilidade para "caixa de Pandora" não está relacionada à concentração em períodos específicos, mas é distribuída aleatoriamente. O gráfico a seguir mostra a frequência de relativa dos temas em "caixa de Pandora":

Figura 18 - Temas em "caixa de Pandora"

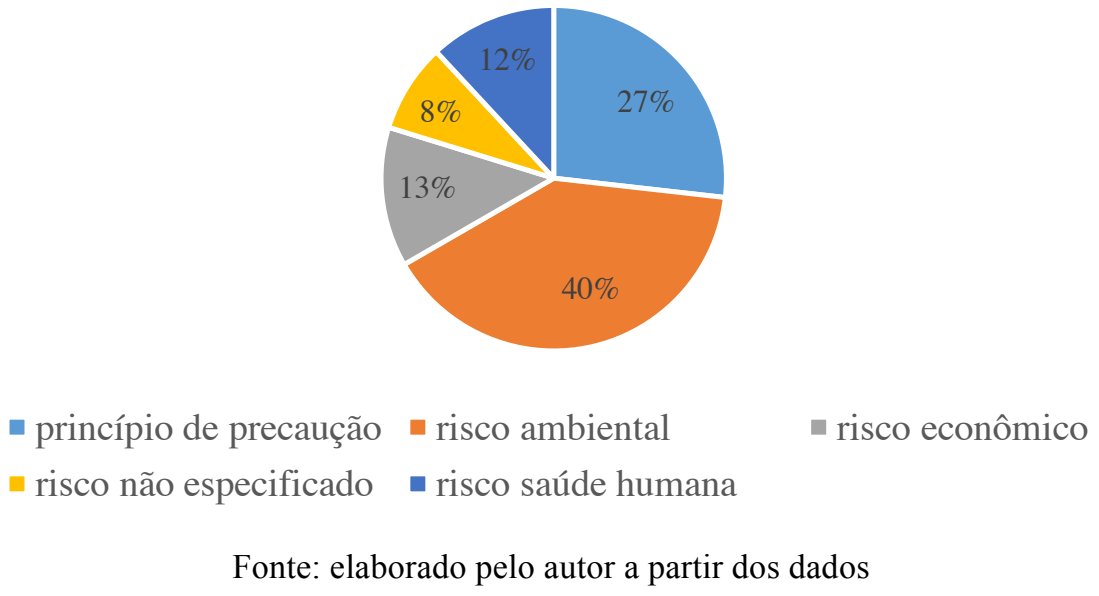

"Risco ambiental" detém 40\% (67 ocorrências), seguido por "princípio de precaução" 27\% (45), "risco econômico" 13\% (22), "risco saúde humana" 12\% (20) e em último lugar se apresenta "risco não especificado" $8 \%$ (14). O tema se referente aos desequilíbrios à biodiversidade, surgimento de pragas/ervas daninhas mais resistentes, maior uso de agrotóxico, morte de espécies e contaminação de culturas convencionais por novos compostos químicos.

"Princípio de precaução" reúne as reportagens que lembram que na ausência de consenso científico irrefutável sobre a segurança dos transgênicos, é melhor não os utilizar. Diz a respeito à ausência de conhecimento sobre os transgênicos e às dificuldades de aceitação face aos seus efeitos desconhecidos.

"Risco a saúde humana" engloba os problemas de saúde, associação a tipos de câncer, contaminação na cadeia alimentar e outras mazelas ao organismo humano.

"Risco econômico" apresenta projeções sobre quais tipos de produtores se tornarão financeiramente dependentes das multinacionais, inviabilização da agricultura familiar, dominação de mercados por indústrias globais, seja pelo monopólio de sementes, seja por 
royalties, seja pela compra obrigatória de determinado agrotóxico e perda de mercados com o fim das exportações.

\subsection{AVANÇO DE “PROGRESSO”}

O histograma abaixo apresenta a evolução da frequência relativa de "progresso":

Figura 19 - Frequência relativa de "progresso" por ano

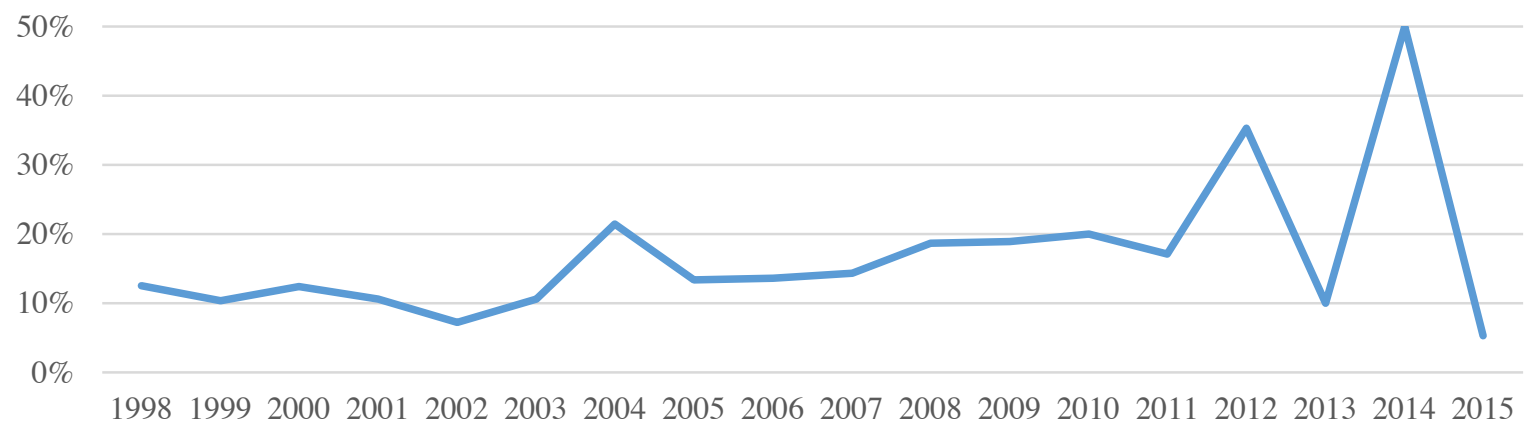

Fonte: elaborado pelo autor a partir dos dados

Podemos notar um crescimento consistente em todo o intervalo de tempo, passando de 13\%, em 1998, para 50\%, em 2014. Em “2015” observamos uma queda brusca, mas não o suficiente para concluir que a tendência de alta terminou. A média de quadros foi de 8 notícias/ano, com desvio padrão de 7 . O próximo gráfico apresenta a frequência relativa dos temas encontrados no enquadramento "progresso":

Figura 20 - Temas em "progresso"

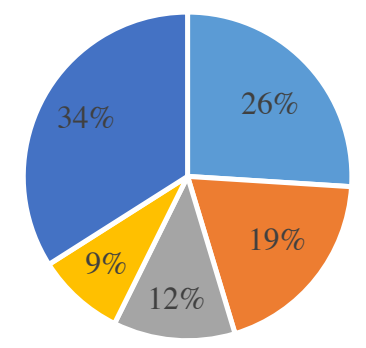

- benefício n especificado

- não há riscos

- produtividade
- benefícios saúde

- oportunidade de desenvolvimento 
Artigos que continham assuntos em torno da "produtividade" constituíram o tema mais abundante no quadro "progresso", detendo 34\% (51 ocorrências) de todo o período, seguido por "benefício não especificado" 26\% (39), "benefícios saúde" 19\% (29), "não há riscos” 12\% (18) e "oportunidade de desenvolvimento" 9\% (13).

"Produtividade" centraliza notícias que abordam o aumento da produção de alimentos agrícolas sem aumentar custos operacionais.

"Benefícios a saúde" apresenta notícias que explicam porque transgênicos podem ser mais nutritivos e funcionais, além de oferecem cura e prevenção de doenças.

"Benefícios ao ambiente" centraliza o menor uso de agrotóxicos e o favorecimento dos transgênicos à biodiversidade.

“Oportunidade de desenvolvimento" realça as possibilidades de desenvolvimento que a biotecnologia traz, tais como potenciais mercadológicos ou de inovação.

\subsection{ONDAS QUE CENTRALIZARAM O DEBATE}

Encontramos três "ondas" nos portais que continham eventos e discursos semelhantes: “Introdução comercial” - de 1998 a 2002 (353 notícias), “Anos da controvérsia” - de 2003/04 (700) e "Controvérsias para além da regulação" - de 2006/11 (343):

Figura 21 - Ondas e frames de notícia

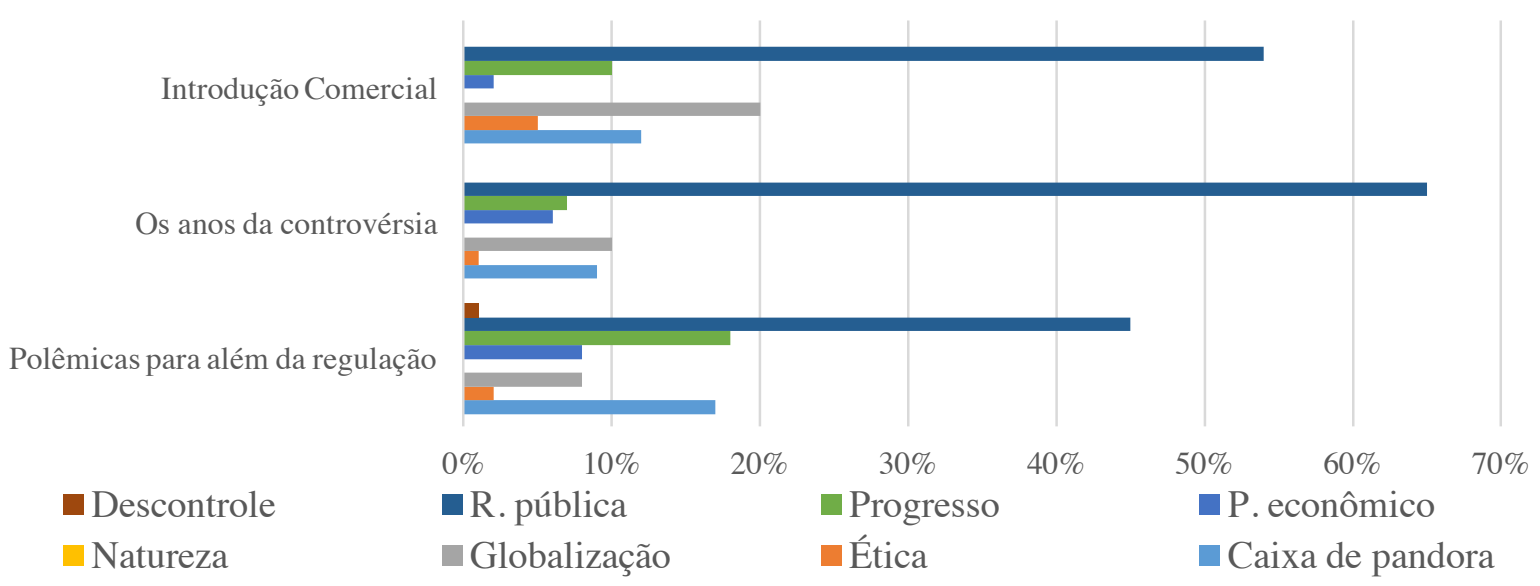

Fonte: elaborado pelo autor a partir dos dados

O padrão de comportamento das ondas corrobora com os dados relacionados às séries históricas de frames analisadas anteriormente: durante os anos da introdução comercial, "participação pública" detém 54\% das observações, valor que sobe para $65 \%$ em meio às 
discussões da regulação por lei e que reduz para 45\% nos anos finais. "Globalização" apresenta expressiva queda. Já "caixa de Pandora" e "progresso" têm um padrão semelhante: ambos tinham uma porcentagem maior nos anos da introdução comercial e, durante o biênio 2003/04, têm seus valores reduzidos. Contudo, nos últimos anos, apresentam uma tendência de crescimento. "Prospecto econômico" cresceu por todas as ondas.

\subsubsection{Introdução comercial: $1998 / 2002$}

O evento que inaugura o debate sobre os transgênicos nos portais, até então pautados eventualmente, ocorreu ao final de 1998, quando a Monsanto do Brasil obteve parecer técnico favorável da CNTBio ao plantio da soja $R R$. Meses antes, a soja transgênica fora contrabandeada da Argentina para alguns estados da região Sul.

Durante o quadriênio 1998-2002, as notícias foram marcadas pelo conflito entre defensores e críticos em um período em que a produção não era regulada por lei específica. Se por um lado não havia proibição clara, por outro, levantava-se a ausência de estudos de impacto ambiental que resguardassem o princípio de precaução, assegurado pela Constituição Federal. $\mathrm{Na}$ maior parte dos casos, as diversas e contraditórias interpretações de cientistas, políticos e outros porta-vozes eram exploradas pelos portais, tendo a polêmica como principal critério de noticiabilidade, ao invés de se atentaram a esclarecer a questão.

Em "responsabilidade pública", era comum a atuação da CNTBio por meio de portarias e pareceres técnicos ou então de tribunais de diferentes instâncias e regiões que judicializavam questões pontuais sobre os transgênicos. Por várias vezes, as decisões jurídicas se contradiziam. Nesses despachos liminares ou colegiais, ora se citava o zelo ao princípio da precaução, ora se justificava a exigência de estudos de impacto, ora se atendia a demandas de governos estaduais e dos setores agrícola e agroindustrial ${ }^{7}$. Também se reportou as sucessivas atuações da mídia ao fiscalizar produtos que continham transgênicos em suas composições ${ }^{8}$, bem como o debate sobre a rotulagem logo após o plantio da soja $R R^{9}$.

\footnotetext{
${ }^{7}$ FSP, "Liberação de transgênicos no país depende da justiça", 27/06/2000; FSP, "Idec aciona justiça contra parecer dos transgênicos", 03/06/2000; FSP, "MS vota lei que proíbe transgênicos, 22/06/1999; ESPD, “Tribunal pede explicações sobre soja transgênica", 01/08/2001.

${ }^{8}$ FSP, "Greenpeace e Idec testam 'alimentos suspeitos", 13/06/2000; FSP, "Transgênicos já são consumidos no Brasil”, 21/06/2000; FSP, “Greenpeace encontra transgênicos em mais quatro produtos brasileiros”, 20/09/2000; ESPD, "Greenpeace retira transgênicos do mercado", 21/09/2000.

${ }^{9}$ FSP, "FHC determina rotulagem para alimentos transgênicos", 02/06/1999; FSP, "Os grãos na mesa",

23/06/1999; FSP, "Público define rótulo de transgênicos”, 06/12/1999.
} 
Em "caixa de pandora", um dos eventos mais noticiados foi o do caso da borboleta monarca nos Estados Unidos e no México, cuja morte foi especulada pela produção do milho $B t^{10}$. Foi comum a presença da autoridade científica nas reportagens:

Mais um estudo em revista científica de primeira linha -desta vez, a britânica 'Nature' - põe em dúvida a segurança da liberação do plantio de culturas transgênicas. Sob suspeita, de novo, está o milho venenoso (FSP, "Lagartas morrem em teste de transgênicos", 20/05/1999).

Apesar da chamada negativa, "Lagartas morrem em teste de transgênicos", nessa mesma notícia, é dado espaço para refutações:

O estudo não preocupa Jezovsek, especialista em biotecnologia da Monsanto (...) que afirma que o pé de milho transgênico produz muito menos toxinas no pólen do que no caule, a parte atacada por outras lagartas. Além disso, na natureza o pólen se degrada rapidamente (FSP, "Lagartas morrem em teste de transgênicos”, 20/05/1999).

Os transgênicos também foram retratados nessa onda de maneira controversa no âmbito internacional ${ }^{11}$. Entre os eventos enquadrados em "globalização", um tipo de acontecimento entre os mais reportados era relativo aos protestos, ocupações e ataques a lavouras transgênicas do Brasil e mundo. Nesses episódios, destacavam-se as atuações do ativista francês José Bové, então dirigente do movimento antiglobalização Via Campesina, e de João Pedro Stédile, líder do MST que em uma série de fóruns, conferências e convenções internacionais reivindicavam os riscos associados aos transgênicos ${ }^{12}$.

\subsubsection{Os anos da controvérsia política: $2003 / 04$}

Os "anos da controvérsia" se caracterizaram como um período agitado de debate político sobre a regulação definitiva dos transgênicos. Com a soja $R R$ já mais ou menos regulada mediante parecer da CNTBio em 1998, além das sucessivas medidas provisórias autorizando sua safra nos anos anteriores, iniciou-se um movimento no qual vários atores políticos buscaram defender seus interesses para uma legislação mais clara e definitiva, que de fato ocorreu em março de 2005 com a sanção lei 11.105 .

Novamente, "participação pública" foi o frame hegemônico, tendo o tema "regulação" como o mais frequente. Os conflitos chegaram a ser protagonizados por integrantes do próprio

\footnotetext{
${ }^{10}$ FSP, "Estudo questiona eficácia de transgênicos, 05/08/1999; FSP, "Estudo polêmico indica perigo de transgênicos", 16/10/1999; FSP, "EUA iniciam debate sobre transgênicos", 13/11/1999.

${ }^{11}$ FSP "EUA e França discutem restrições de países europeus a transgênicos", 30/06/1999, FSP “Japonês encontra milho transgênico em produto importado dos EUA", 25/10/2000.

12 ESPD, "Bové acusa governo de tentar intimidar o fórum e o MST", 30/01/2001; ESPD, "Olívio demonstra solidariedade a Bové", 30/01/2001; FSP, "Tribunal condena Bové a 3 meses de prisão por destruir McDonald's", 23/03/2001; ESPD, “José Bové é condenado a 14 meses de prisão”, 19/11/2002.
} 
Governo Federal, à exemplo dos entre os ministérios do Meio Ambiente (Marina Silva) e da Agricultura (Roberto Rodrigues) ${ }^{13}$.

Um primeiro desses confrontos se deu quando um projeto de lei apresentado pelo governo visava flexibilizar o poder de regulação da $\mathrm{CNTBio}^{14}$. A então presidente da Anbio, que compunha uma cadeira na CNTBio, se pronunciou contrariamente:

Esse projeto não tem lógica, é inédito no seu absurdo, pois diz que a CTNBio só poderá dar parecer técnico negativo [aos pedidos de liberação de pesquisa de produtos geneticamente modificados] (FSP, "Poder da CTNBio divide especialistas", 30/10/2003).

A mesma reportagem recorria a um contraponto, uma especialista da área de Agronomia avaliava como o projeto de lei como um avanço:

Não existe unanimidade em questões técnicas: a análise dos transgênicos envolve diferentes áreas do conhecimento e sua liberação afeta as gerações futuras. Por isso a decisão não pode ficar nas mãos apenas dos cientistas" (FSP, "Poder da CTNBio divide especialistas", 30/10/2003).

Outro impasse que ilustra o enfoque para as controvérsias e incertezas ocorreu no caso em que uma decisão do TRF da primeira região, com sede em Brasília, envolvia as empresas Monsanto do Brasil e Monsoy na comercialização de soja transgênica sem estudos de impacto. Os opositores exigiam que fosse observado o princípio de precaução. Paradoxalmente, em outro processo, mas no mesmo tribunal e data, foi mantida uma liminar que vedava a comercialização das sementes da soja $R R^{15}$. O advogado que representava os interesses da Monsanto se pronunciou a respeito dessa ambiguidade:

"Foi uma decisão inusitada", afirmou Passarinho [advogado da Monsanto]. "A maioria dos desembargadores decidiu que a liberação pela CTNBio é constitucional. No entanto, continua valendo a cautelar (liminar) que proibiu" (ESPD, "Em decisão ambígua, TRF mantém veto a transgênico", 28/06/2004).

Muito semelhante à onda "Introdução Comercial", também podemos notar em 2003 e 2004 a intensificada judicialização da questão, principalmente quando houve a discussão e a

\footnotetext{
${ }^{13}$ FSP, "Marina Silva pede suspensão de ação que 'libera' transgênico", 05/02/2003; ESPD, "Congresso pode aprovar transgênicos este ano, diz Rodrigues", 31/03/2003

${ }^{14}$ FSP, "Poder da CTNBio divide especialistas", 30/10/2003.

${ }^{15}$ ESPD, "Em decisão ambígua, TRF mantém veto a transgênico", 28/06/2004.
} 
liberação pontual das safras desses anos ${ }^{16}$. Exemplo de notícia que abordou esse conflito ocorreu quando o então Procurador-Geral da República, Claudio Fonteles, ingressou na Suprema Corte contra a MP que liberava a safra de soja transgênica já plantada ${ }^{17}$. Com o subtítulo "polêmica", era noticiado:

Sobre a necessidade da liminar, Fonteles argumentou que o tema é importante e que há risco de "comprometimento da ordem social e da segurança jurídica" (FSP, "Procurador vai ao STF contra transgênicos", 04/10/2003).

Vários pontos contrariando os interesses de grandes produtores, políticos da bancada rural e o próprio governo foram levantados pelo procurador: (i) ao editar a MP, o governo feriu a norma que exige a urgência desse instrumento; (ii) a necessidade de estudos prévios de impacto que assegurem que não há riscos; (iii) ofensa ao princípio de independência entre os poderes, uma vez que a matéria deveria ser amplamente discutida; (vi) violação do princípio democrático, que prevê a participação pública e; (v) violação do princípio da razoabilidade, que se refere ao bom-senso que deve ser aplicado ao direito.

Outro evento ocorreu durante o mês de setembro, em 2003, quando a cobertura midiática se voltou para edição da MP 131, que liberava o plantio de sementes da soja $R R$ para a safra de 2003. O então Presidente da República em exercício, José Alencar Gomes da Silva, relutou em autorizá-la, chegando a adiá-la por dias seguidos, dada a pressão de ministros, grupos políticos, ambientalistas e outros ativistas ${ }^{18}$ :

\footnotetext{
"Conversei com técnicos da Embrapa, que disseram que não há riscos, mas os ambientalistas afirmam que há riscos", afirmou [José Alencar]. "É uma situação difícil, e vocês devem estar com pena de mim" (ESPD, "Alencar faz desabafo sobre MP que libera transgênicos", 24/09/2003).
}

A escolha de palavras utilizadas para reportar o fato também se sobressai: "mal-estar", quando foi encarada a situação, comparando a discussão em torno dos transgênicos com um "atropelamento"19, pela ausência de ampla discussão. Em outra notícia, José Alencar em

\footnotetext{
${ }^{16}$ ESPD "AGU vai preparar saída jurídica para a soja transgênica”, 07/03/2003; FSP, "Ministro da Agricultura admite venda de transgênicos no país", 18/03/2003; FSP, "MP dos transgênicos já recebeu 71 emendas no Congresso", 03/04/2003; FSP, "Sem mudança, há caos legislativo, afirma ministro", 29/04/2003

${ }^{17}$ FSP, "Procurador vai ao STF contra transgênicos", 04/10/2003.

${ }^{18}$ ESPD, "Governo decide sobre transgênicos esta semana, diz ministro", 30/08/2003; ESPD, "Protesto contra MP dos transgênicos em Brasília”, 09/08/2003; FSP, "Decisão sobre transgênicos deve sair só na quarta”, 23/09/2003; ESPD, "Alencar faz desabafo sobre MP que libera transgênicos", 24/09/2003; FSP, "MP da soja transgênica era questão de emergência, diz ministro", 29/09/2003.

${ }^{19}$ FSP, “José Alencar assina MP e libera plantação de soja transgênica", 25/09/2003.
} 
pronunciamento na câmara baixa emprega o termo "desobediência civil" para explicar que o contrabando e o cultivo sem regulação não deveria ser tolerado ${ }^{20}$.

Em 2004, há uma ligeira mudança na forma como os acontecimentos relacionados à regulação eram noticiados. O debate passa a ser mais centralizado em torno do projeto da Lei de Biossegurança (PL 2401), que veio a ser sancionado em março do ano seguinte. Mas nem por isso as notícias deixaram de ter controvérsias políticas como critério de noticiabilidade elementar ${ }^{21}$. O trecho selecionado a seguir é bastante ilustrativo:

Parlamentares da Frente da Biossegurança entregaram hoje ao relator do projeto da Biossegurança sugestões de alterações no substitutivo apresentado pelo ex-relator Aldo Rebelo, que vem sofrendo críticas da Frente e de ambientalistas (FSP, "Deputados pedem alterações em projeto de biossegurança", 28/01/2004).

Nesse caso, houve mudança de relator, por conta de disputas políticas e, além disso, tanto defensores (a "Frente") como opositores (os "ambientalistas") eram contrários, por diferentes razões, ao projeto de lei como era apresentado. Dentre os próprios aliados do então governo houve acentuada articulação política no PL 2401. Podemos perceber isso no episódio em que o então senador Ney Suassuna (PMBD/PB) atuou para que algumas emendas pudessem contemplar pontos divergentes:

Se a proposta de legalizar o plantio de transgênicos for aprovada em tempo hábil, ficará autorizado plantio de 200 mil sacas de sementes de soja, afirma Suassuna. Mas para aprovar essa emenda ao projeto, será preciso negociar não só com a oposição, mas também com o próprio partido do presidente Luiz Inácio Lula da Silva. O senador [Ney] Suassuna [PMDB/PB] admite que terá problemas com a ministra do Meio Ambiente, Marina Silva. 'Mas eles terão de segurar a barra', observou, numa referência também a outros setores do PT que resistem à liberação do plantio de soja transgênica. Além de negociar com os partidos políticos em busca de apoio à proposta, Suassuna disse que outros dois obstáculos terão de ser superados: a proximidade das eleições municipais e a votação de 17 medidas provisórias (ESPD, "Senador articula legalização de plantio de soja transgênica", 09/09/2004).

Em geral, os atores políticos contrários à regulação alertavam sobre os riscos de saúde alimentar, sociais e ambientais, argumentando que a maioria da população era contrária aos organismos desse tipo ${ }^{22}$. Defensores, por sua vez, proferiam que os transgênicos não tinham

\footnotetext{
${ }^{20}$ FSP, “Desobediência civil cresce no país, diz Alencar", 30/10/2003.

21 FSP, "Deputados pedem alterações em projeto de biossegurança", 28/01/2004; ESPD, "Projeto de Biossegurança ainda envolto em muita polêmica", 29/01/2004; ESPD, "A Lei de Biossegurança volta a vigorar", 14/09/2004; FSP, "Relator apresenta parecer sobre Biossegurança e sugere fatiar projeto", 13/09/2004.

${ }^{22}$ FSP, "Procurador-geral vai ao Supremo contra lei que libera transgênicos", 14/01/2004; FSP, "Opiniões extremas emperram debate", 06/02/2004; FSP, “Greenpeace faz protesto contra transgênicos”, 26/01/2004.
} 
quaisquer riscos ${ }^{23}$ e que se tratavam de um produto do avanço tecnológico ${ }^{24}$. Mais que isso: a CNTBio não teria competência para regular e, portanto, deveria limitar-se a coordenar pesquisas científicas ${ }^{25}$. Não obstante, ambos os portais deram destaque à articulação do Governo Federal em atender a todos os lados, ainda que alguns de seus representantes argumentassem que isso era impossível ${ }^{26}$.

Chama atenção em 2004 o léxico mencionado pelos portais na retratação dos eventos relacionados à regulação: "opiniões extremas", "Maradona versus Gérson", "luta entre ministérios", "guerra política”, "briga pela regulamentação", "estado de ilegalidade”, "regras que atrapalham", "confusão danada", "polêmica", "debate quente”, "divisão", "falta de uma posição clara", "patacoada transgênica", "decisão entre a cruz e a espada", "semana decisiva", “disputa no Senado", “decisão salomônica”, "assunto árduo”, "pomos da discórdia”, "lenha na fogueira da polêmica" e "derrota com a edição da MP".

Quatro textos de autoria de Marcelo Leite, colunista e editor-chefe da área de Ciência da Folha de S. Paulo, se destacaram no período. Em "A comédia dos transgênicos"27, afirma que o "Governo Lula legalizou a ilegalidade largamente praticada por agricultores" quando foi emitida uma MP que autorizava o plantio da soja geneticamente modificada, ainda que não houvesse lei específica sobre ela.

Poucas semanas depois, em "A comédia dos transgênicos 2", comenta sobre as repercussões na questão em torno da propriedade intelectual da soja $R R$ que foi assegurada, uma vez que "a pirataria foi obliquamente reconhecida e oficializada pelo governo" 28 .

Em "George, Charles e os transgênicos"29, faz alusão à George Bush, então presidente dos EUA e defensor, e o príncipe Charles, conhecido por alertar para os riscos da biotecnologia, expondo a polarização entre EUA e UE. Nesse artigo, ele alerta contra as falsas dicotomias “empobrecedoras" entre defensores e opositores que acabavam por alimentar ainda mais o confronto. A audiência deveria se aprofundar na discussão, caso contrário, tornar-se-ia "refém dos fundamentalistas estéreis".

\footnotetext{
${ }^{23}$ ESPD, "Cientistas vêem avanço em texto de biossegurança”, 07/10/2004.

${ }^{24}$ ESPD, "Biossegurança em engenharia genética: quando o Estado titubeia", 04/10/2004.

${ }^{25}$ ESPD, "Projeto de Biossegurança ainda envolto em muita polêmica"; 28/01/2004.

${ }^{26}$ ESPD, "Paraná pode ser área livre de transgênicos, diz José Dirceu”, 14/01/2004; FSP, "A cruz e a espada", 03/02/2004; FSP, "Sem consenso, projeto de biossegurança vai a plenário na Câmara", 04/02/2004; ESPD, "Rodrigues pedirá a Lula solução para o plantio de transgênicos", 16/09/2004.

${ }^{27}$ FSP, “A comédia dos transgênicos", 06/04/2003.

${ }^{28}$ FSP, “A comédia dos transgênicos 2", 18/05/2003.

${ }^{29}$ FSP, "George, Charles e os transgênicos" 13/07/2003.
} 
Por último, em "Patacoadas transgênicas",30, o próprio editor da Folha criticava a imprensa, afirmando que estava "difícil ler coisas sérias sobre alimentos transgênicos, contra ou a favor, em particular na imprensa leiga". Indicou que, nas discussões, a presença de leigos prejudica o debate: "houve até quem dissesse que os inimigos dos transgênicos os atacam porque provocariam alterações da genética humana, o que constitui um disparate duplo".

As controvérsias não se limitaram apenas aos eventos noticiados acerca da regulação. Logo no início de 2003, os organismos transgênicos entraram como uma das pautas principais do terceiro Fórum Social Mundial, realizado em Porto Alegre/RS. Notáveis organizações de presença em diversos países, e.g., Greenpeace, MST e Via Campesina, associavam a introdução desses organismos como uma estratégia de dominação global, na qual poucas multinacionais controlariam os mercados agrícolas:

Nossa estratégia central é defender as sementes como patrimônio da humanidade e não de empresas particulares [Dirigente Via Campesina] (ESPD, "Fórum Social Mundial terá propostas para mudar o mundo", 19/01/2003).

Ainda sobre as notícias que tratavam dos transgênicos em plano global, enquadradas em "globalização, foram reportados diversos conflitos comerciais entre nações ou blocos continentais, como Brasil e Paraguai ${ }^{31}$, EUA e $\mathrm{UE}^{32}$, e mesmo entre os próprios países da Europa $^{33}$, havendo inclusive o pronunciamento de autoridades do Vaticano ${ }^{34}$.

\subsubsection{Controvérsias para além da regulação: $2005 / 15$}

Esse período apresenta uma redução na quantidade de notícia, com enfraquecimento de "responsabilidade pública" e "globalização e avanço de "progresso". A onda se inicia em 2005 com somente sete notícias sobre a sanção da "Lei da Biossegurança"35, o que de certa forma surpreendeu, dada a atenção dos portais ao acalorado debate sobre a regulação ocorrido na onda

\footnotetext{
${ }^{30}$ FSP, “Artigo: Patacoadas transgênicas”, 14/09/2003.

${ }^{31}$ ESPD, “Acordo permite exportação de soja transgênica”, 31/10/2003.

${ }^{32}$ ESPD, "Europa repudia pressão de Bush por transgênicos", 24/06/2003; FSP, "União Européia agrava fome africana, diz Bush”, 25/06/2003; FSP, “Estados Unidos são produtor campeão de transgênicos”, 11/09/2003; FSP, "Bush pressiona Europa para aceitar transgênicos", 23/07/2003; FSP, "Bush volta a criticar política européia sobre transgênicos", 25/07/2003.

${ }^{33}$ ESPD, "União Européia adia decisão sobre transgênicos", 10/11/2003.

${ }^{34}$ ESPD, "Vaticano promove seminário sobre alimentos transgênicos", 10/11/2003.

${ }^{35}$ FSP, "Aprovação também vale para transgênico", 03/03/2005; FSP, "Planalto faz concessões a ambientalistas", 25/03/2005; ESPD, "Pesquisadores comemoram sanção da Lei da Biossegurança", 26/03/2005; FSP, "Lei aprova semente geneticamente modificada", 07/05/2005; ESPD, "Fonteles pede inconstitucionalidade da lei de biossegurança", 21/06/2005", ESPD, "Governo nega atraso na Lei de Biossegurança", 24/08/2005; FSP, "Lei de transgênicos atende a ambientalistas", 25/11/2005.
} 
anterior. Isso é mais um indício de que as controvérsias e confrontos políticos são de fato os critérios de noticiabilidade mais determinantes na mídia paulista.

Apesar desse episódio ter concentrado uma quantidade reduzida de notícias, pelo fato de ser um dos marcos mais importantes da regulação da biotecnologia agrícola, o acontecimento foi rememorado em outras ocasiões, até mesmo uma década depois ${ }^{36}$.

O ínterim 2005/15 foi marcado pela queda acentuada da frequência do tema "regulação" entre as notícias, deixando de ser a principal pauta abordada no frame "participação pública". Diferentemente de 2003 e 2004, as notícias em "participação pública” não abordavam mais a Lei 11.105, mas nem por isso as polêmicas e conflitos deixam de ser o principal objeto da atenção, sendo noticiados temas diversos, tais como a liberação pontual de variedades transgênicas $^{37}$, a eticidade de sementes terminator ${ }^{38}$, a definição de novas políticas para espécies já reguladas ${ }^{39}$, a mobilização de vários atores políticos para flexibilização das regras vigentes $^{40}$, a associação de ONGs contra a biotecnologia ${ }^{41}$ e protestos contra transgênicos ${ }^{42}$.

O triênio 2012/14 em específico apresentou algumas notícias no que diz a respeito às patentes de sementes transgênicas. Um exemplo se dá quando a Monsanto do Brasil suspende a cobrança de royalties da soja $R R$ após a determinação jurídica ${ }^{43}$. Outro, quando ONGs e empresas brasileiras acusam de lobby o fato de a mesma multinacional ter pago cursos sobre transgênicos para o $\mathrm{INPI}^{44}$, repercutindo o conflito também nos anos 2013 e $2014^{45}$.

\footnotetext{
${ }^{36}$ FSP, "Rótulo para informar, não para confundir", 18/05/2015; ESPD, "Projeto de lei propõe fim de símbolo específico em alimentos transgênicos", 10/05/2015.

${ }^{37}$ FSP, "Juíza libera soja modificada em Paranaguá,, 30/03/2006; ESPD, "CTNBio reúne-se para discutir liberação de transgênicos", 19/09/2006; ESPD, "CNTBio libera uso de mais três plantas transgênicas", 19/09/2008; ESPD, "CNTBio discute liberação de arroz transgênico", 18/03/2009.

${ }^{38}$ ESDP, "Brasil é contra uso de sementes transgênicas estéreis", 22/03/2006; FSP, "convenção proíbe uso de semente suicida", 25/03/2006; ESPD, "Brasil é contra uso de sementes transgênicas estéreis", 22/03/2006.

${ }^{39}$ FSP, "Ministério define áreas vetadas à plantação de algodão transgênico", 17/01/2006; ESDP, "CNTBio manda destruir lavouras transgênicas de algodão", 21/06/2006; ESPD, "Justiça suspende liminar e libera milho transgênico", 19/01/2008; ESPD, "Prioridade é criar um novo marco legal", 22/01/2011.

${ }^{40}$ FSP, "Senado aprova mudanças em biossegurança", 28/02/2007; FSP, "Mudança facilita liberar transgênico", 22/03/2007; ESPD, "Governo cogita revogar lei da biossegurança", 21/07/2007.

${ }^{41}$ ESPD, "ongs reclamam de processo de aprovação", 05/09/2011.

${ }^{42}$ FSP, "Via Campesina ocupa empresa Monsanto em São Paulo", 07/03/2008; ESPD, "Greenpeace prepara protesto contra transgênicos em SP", 08/03/2008; ESDP, "Greenpeace destrói plantações de trigo transgênico na Austrália" 14/07/201; FSP, "Greenpeace destrói plantações de trigo transgênico na Austrália" 14/07/2011.

${ }^{43}$ FSP, "Monsanto vai à justiça para cancelar liminar concedida aos produtores", 10/10/2012; ESDP, "Monsanto suspende cobrança de royalties da soja RR no Brasil", 17/10/2012.

${ }^{44}$ ESDP, "ONGs questionam curso sobre patentes"; $25 / 10 / 2012$; ESPD, "empresas brasileiras criticam apoio do INPI a empresas multinacionais", 26/10/12.

${ }_{45}$ ESDP, "Monsanto diz que acordo elimina cobrança de royalties da soja RR", 23/01/2013; ESPD, "CADE suspende julgamento de 4 operações da Monsanto", 20/03/2013; FSP, "Os sibaritas e as patentes", 22/06/2014.
} 
Para "globalização", nos últimos anos há um novo enfoque: se antes os conflitos e controvérsias compunham os temas frequentes no período de pré-regulação, agora "cooperação internacional" passa a ser o tema predominante (47\% das observações). As notícias abordavam o papel estratégico do Brasil ${ }^{46}$, segundo maior produtor de transgênicos no mundo, a alta no valor das commodities, além das altas taxas de crescimento econômico experimentadas pelo país, inclusive em um momento posterior à crise financeira mundial de $2008^{47}$.

Em 2015, destacou-se uma grande mobilização de políticos para o fim dos símbolos de transgênicos em rótulos ${ }^{48}$. Um projeto de lei que tramitou na Comissão de Agricultura e Reforma Agrária (CRA) do Senado debatia o fim da exigência de símbolo para produtos com composição maior que $1 \%$. De acordo com os portais, a indústria alimentícia, em associação com a bancada ruralista, há tempos argumentava que o símbolo inibe o consumo:

O projeto é de autoria do deputado Luiz Carlos Heinze (PP-RS). Segundo ele, a mudança proposta não vai omitir informações (...) "Acho que o Brasil pode adotar a legislação como outros países do mundo. O transgênico é um produto seguro” (ESDP, "Câmara aprova projeto que 'camufla' produtos transgênicos", 29/04/2015).

Nas discussões políticas, o PT e outros partidos tentaram impedir o avanço da proposta:

Contrário à proposta, o deputado Alessandro Molon (PT-RJ) disse que o projeto de lei cassa, na prática, o direito de o consumidor saber se há ou não transgênicos. "É correto sonegar ao consumidor essa informação? ", questionou (ESDP, "Câmara aprova projeto que 'camufla' produtos transgênicos", 29/04/2015).

Outro trecho permite observar explicitamente a intensidade do conflito:

A regra já era bastante burlada e sua supressão é uma bandeira antiga da indústria alimentícia. O argumento defendido pela bancada ruralista (FSP, "Câmara aprova projeto que acaba com símbolo dos transgênicos em rótulos”, 28/04/2015).

\footnotetext{
${ }^{46}$ ESPD, "Para OMS transgênicos são seguros. Por enquanto", 23/06/2005; ESPD, "Brasil pode se tornar gigante em biotecnologia, diz estudo", 06/06/2008.

${ }^{47}$ ESPD, "Comércio entre Brasil e Israel pode dobrar, diz Furlan”, 27/07/2005; FSP, "Cingapura busca ser ponte entre América Latina e Ásia”, 11/09/2005; FSP, "EUA querem ampliar parceria com o Brasil, diz embaixador”, 20/02/2007; ESPD, "Questão genética é nó nas reuniões de Lula e Chávez”, 30/09/2008; ESPD, "Capitalismo em cuba atrai brasileiros”, 25/09/2009; ESPD, "Grandes investidores espanhóis querem ampliar negócios no Brasil”, 27/01/2011; FSP, "China quer sincronia com Brasil em transgênicos", 23/02/2014)

${ }^{48}$ FSP, "Câmara aprova projeto que acaba com símbolos de transgênicos em rótulos", 28/04/2015; ESPD, "Câmara aprova projeto que 'camufla' produtos transgênicos", 29/04/2015.
} 
Nesse aspecto, os portais demonstraram preocupação em relação à sobreposição de interesses de grupos a interesses públicos, havendo grave atentado à democracia nas tentativas de mudanças nos rótulos de produtos com transgênicos ${ }^{49}$.

No segundo semestre de 2015, após uma grande reação de diversos agrupamentos da sociedade civil, especialmente IDEC, MPF e Greenpeace, o projeto da Câmara dos Deputados, que chegou a ser aprovado, foi barrado no Senado Federal. Esse desfecho, entretanto, sequer foi noticiado. Isso indica que, antes de prestar informações "com o compromisso com a democracia" e "de produzir notícias com base nos princípios de independência, espírito crítico, pluralismo e apartidarismo", princípios das missões editorais dos grupos Estado e Folha, os jornais são mais preocupados com eventos que atendam a um conjunto de critérios de noticiabilidade. Nesse caso, a não aprovação do projeto no Senado e na Câmara provavelmente não continha algum elemento de controvérsia política.

\footnotetext{
${ }^{49}$ FSP, “Congresso transgênico, 03/05/2015; FSP, "Rótulo para informar, não para confundir”, 16/05/2015; ESPD, "Câmara aprova projeto que 'camufla' produtos transgênicos", 29/04/2015; FSP, "símbolo deve ser mantido nas prateleiras? Sim", 16/05/2015; ESPD, "Projeto de lei propõe fim de símbolo específico", 20/05/2016; ESPD, "Alimentos transgênicos em debate", 29/09/2015.
} 


\section{CONSIDERAÇÕES FINAIS}

Frames são dispositivos culturais que estruturam a experiência social e os sentidos da vida cotidiana. Enquadrar um risco ambiental é fazer mais salientes algumas de suas possibilidades que, por sua vez, promovem uma ou outra interpretação. No processo de produção de notícias para transgênicos, a mídia se apropria desses padrões culturais já legitimados, disseminando e amplificando os frames dominantes de certa sociedade. Identificar e analisar os frames de transgênicos nos portais Estadão Digital e Folha de S. Paulo contribuiu para uma melhor compreensão da estruturação pública e política da maneira pela qual a pauta tem sido abordada na imprensa paulista. Nesse sentido, frames de notícia subsidiam a opinião pública e favorecem a mobilização coletiva para regulação e a deliberação sobre quais níveis de riscos a sociedade está disposta a se relacionar.

Nossa escolha pelo método de análise de frames, com forte embasamento na sociologia construcionista, se mostrou uma alternativa original à imprensa brasileira. Não nos limitamos a apresentar o conteúdo manifesto das reportagens, tampouco a investigar a arena midiática como um espaço de construção, negociação e legitimação de frames. Pelo contrário, para além de reconhecer a importância das ações dos atores nos bastidores da produção de notícias, pudemos considerar aspectos singulares da mídia, levando em conta fatores tais como interesse, impacto na vida cotidiana, frequência e amplitude de veiculação, etc.

Por esse motivo, a revisão bibliográfica para o newsmaking se mostrou fundamental a análise. Notamos que os eventos de polêmica e conflito entre atores para a regulação indicaram maiores "valores notícia". Diante de tantas incertezas técnicas e sociais para a biotecnologia, a mídia paulista acaba reverberando posições de diferentes atores que detêm frames paradoxais. Assim, a controvérsia se mostrou a matéria-prima mais acionada independente do fato noticiado. Esse modo de operar acabou restringindo um debate que contemplassem informações mais plurais e esclarecedoras, que qualificasse a audiência para melhor deliberar sob quais circunstâncias a biotecnologia agrícola deve ser adotada.

À par disso, em um exercício de autocrítica, os portais deveriam policiar um pouco mais a cobertura que apela excessivamente às controvérsias, para além de uma narrativização sensacionalista que apela a critérios de noticiabilidade que raramente levam a uma discussão aprofundada. Nessa orientação, o enquadramento dos jornais poderia seguir a perspectiva temática de Rothberg (2010), a fim de contextualizar a questão, equilibrar os lados e oferecer maior pluralidade para as distintas interpretações. 
Outra alternativa seria uma atuação orientada à teoria de "equidade de informações", proposta por Priest (1994). Desse modo, priorizar-se-ia a discussão dos impactos sociais e ambientais dos transgênicos, pois estes são o que de fato influenciariam a vida cotidiana. Em termos práticos, a imprensa poderia ser mais povoada pelos atores que se percebem como vulneráveis e que poderiam trazer situações concretas e hipotéticas detalhando os impactos ambientais, sociais e econômicos causados em diferentes cenários com a regulação.

Sobre o posicionamento de nossos resultados na literatura, corroboramos com os dados de Maeseele (2007) e Reinhart (2007), que observaram a supremacia de "responsabilidade pública" e pouca participação de "progresso", da segunda metade de 1990 até 2006. No entanto, de acordo com os achados de Gastrow (2010) para o quinquênio 2005/10, "responsabilidade pública" perde sua importância na última década, ao passo que "progresso" exibe um crescimento de mais de 50\%, tendência encontrada em nossa série temporal. Esses resultados têm apontado que os frames para as discussões públicas para a transparência de procedimentos, maior envolvimento e participação nas regulações têm cada vez mais perdido força. Mesmo que tal padrão persista nos próximos anos, é preciso lembrar que frames não são perpétuos, podem ser questionados e a intensidade com a qual os atores interessados se mobilizaram nas variadas arenas podem determinar novos quadros para transgênicos.

Em relação à imprensa brasileira, nossos resultados corroboraram com os de Petrarca (2005), Menasche (2005) e Brossard et al. (2013) quando destacaram o argumento polêmico como um dos principais, senão o mais. Em duas ondas encontramos recortes temporais análogos aos de Allain et al. (2009), um período com o debate mais voltado a introdução comercial dos transgênicos (1998/2002) e outro mais voltado a sua regulação (2003/04). Notamos também uma tendência de crescimento consistente ao longo dos anos para "progresso" no Estadão Digital não encontrada na Folha de S. Paulo, em conformidade com os resultados de Rothberg e Berbel (2010) para esses jornais em sua versão impressa.

A realização dessa dissertação lançou luz a algumas limitações e lacunas que podem vir a serem superadas e exploradas em estudos futuros. Uma primeira limitação se dá em razão da escolha da unidade de análise de um frame por notícia. Tal opção nos obrigou a limitar todo o conteúdo dos artigos em um único frame, ainda que por muitas notícias, dado o espaço cedido a distintos fontes e entrevistados poderiam oferecer mais frames. Poderíamos ter observado frames dominantes e frames auxiliares, por constatarmos que frames diferentes foram acionados em muitos artigos, com a impressão de que a FSP tem quadros mais plurais. Outra tipologia, que capturasse melhor os quadros para "polêmica", também poderia ser empregada. 
Um segundo vício se refere a escolha de utilizar apenas a palavra-chave "transgênicos", deixando de lado todo um léxico que poderia formar um corpus menos suscetível a certos vieses, tais como biotecnologia, biotecnologia agrícola, manipulação genética, modificação genética, engenharia genética, bioengenharia, soja $R R$, milho Bt, milho Starlink, organismo modificado, planta modificada, etc. Por exemplo, observamos que nos artigos recuperados por "biotecnologia" houve maior frequência relativa (porcentagem) para "progresso" e "prospecto econômico" quando comparados com aqueles recuperados por "transgênicos", que apresentavam mais "participação pública" e "caixa de Pandora".

Notamos oportunidades para examinar as interações, ações, dinâmicas, estratégias, relações, conflitos e alianças nas arenas científica e política e seus respectivos atores para a construção dos quadros de transgênicos e sua legitimação na mídia. Assim, poder-se-ia levantar as seguintes questões: como a mídia se apropria de um conteúdo altamente técnico para biotecnologia? Como a ciência se transforma em um produto jornalístico? Qual o peso do olhar jornalístico sobre as informações científicas e riscos? Como grupos marginalizados se articularam politicamente para que seus quadros virem notícia?

No decorrer da busca bibliográfica, tivemos contato com estudos que promoveram entrevistas com profissionais do jornalismo e outras fontes notáveis, compreendendo suas motivações, interesses, orientação editorial e visão de mundo ao enquadrar os transgênicos. Seria pertinente relacionar esse tipo de dado com o conteúdo manifesto das notícias, observando os bastidores da produção de notícia. A sondagem para esses atores é relativamente fácil, basta levantar nas notícias aqueles que são mais noticiados.

Por último, mas não menos importante, diversas pesquisas observam as associações da "tríade" formada pela opinião pública, agendamento da mídia (media setting) e enquadramento de transgênicos. Poder-se-ia, por exemplo, seguir o modelo conceitual de Bauer (2002) para os movimentos sociais por trás dos transgênicos. No Brasil, em virtude de carecermos de levantamentos de opinião pública, essa possibilidade poderia ficar limitada a um recorte das opiniões do momento, impossibilitando verificar as relações com a mídia no decorrer dos anos. Ainda assim, há levantamentos feitos pelo Ibope, Labjor e outras organizações em 2001, 2002 e 2003, anos em que os transgênicos apresentaram grandes quantidades de notícias. 


\section{REFERÊNCIAS BIBLIOGRÁFICAS}

ALEXA. Alexa Internet inc. Acesso em 04/11/2015. Disponível em <www.alexa.com>.

ALLAIN et al. As representações sociais de transgênicos nos jornais brasileiros. Estudos de Psicologia, v.14 (1), 2009.

ANDERSON, A. Media, culture and the environment. New Brunswick, NJ: Rutgers University Press, 1997.

BARDIN, L. Análise de conteúdo. Lisboa: edições 70, 1995.

BAUER et al. The dramatization of biotechnology in elite mass media, 2001. In: The years of controversy: biotechnology 1996-2000, London Science Museum, 2001.

BAUER, M. Arenas, platforms and the Biotechnology Movement. Science Communication, 24 (2). 144-161, 2002.

BECK, U. Risk society, towards a new modernity. London: Sage Publications, 1992.

BERGER, P. LUKHMANN, T. A construção social da realidade: tratado de sociologia do conhecimento. $10^{\mathrm{a}}$ ed. Vozes, [1966] 1985.

BONFADELLI et al. Mass media and public perceptions of red and green biotechnology: a case study from Switzerland. In: Brossard, Shanahan, Nesbitt (Eds). The Public, the Media, and Agricultural Biotechnology. Cambridge, MA: Oxford University Press, 2007.

BORAH, P. Conceptual issue in framing theory: a systematic examination of a decade's literature. Journal of Communication, International Communication Association, 2011.

BOTERO, A. BRABOW, A. Social construction of health risk: rhetorical elements in Colombian and U.S. News Coverage of coca eradication. Communication and social change, v.1, n.1, 19-43, 2013.

BOYKOFF, M. Media discourse on the climate change slowdown. Nature, v.4 I3, 2014.

BROSSARD, D. SHANAHAN, J. Perspectives on communication about agricultural biotechnology. In: D. Brossard, J. Shanahan \& T.C. Nesbitt (Eds.). The Public, the Media, and Agricultural Biotechnology. Cambridge, MA: Oxford University Press, 2007.

BROSSARD et al. Media frame building and culture: transgenic crops in two Brazilian newspapers during the "Year of Controversy". Revista da Associação Nacional dos Programas de Pós-Graduação em Comunicação, Brasília, v.16, 2013.

BRYANT, J. MIRON, D. Theory and research in mass communication. Journal of Communication, v.54, 662-704, 2004.

CORREIA, J. O admirável mundo das notícias: teorias e métodos. Livros LabCom, 2011.

COX, R. DEPOE, S. Emergence and growth of the field environmental communication. In: The Routledge handbook of environment and communication. Routledge, 2015. 
DAHINDEN, U. Biotechnology in Switzerland: frames in a heated debate. Science Communication, v. 24, 2002.

DAKE, K. Myths of nature: culture and social construction of risk. Journal of Social Issues, 48(4): 21-37, 1992.

DI GIULIO, G. Risco, ambiente e saúde: um debate sobre comunicação e governança do risco em áreas contaminadas. São Paulo: Annablume: Fapesp. 2012.

DI GIULIO et al. O papel da mídia na construção social do risco: o caso Adrianópolis, no Vale do Ribeira. Hist. Cienc. Saúde-Manguinhos, 2008.

DOUGLAS, M. WILDAVSKY, A. Risk and culture: an essay on the selection of technological and environmental dangers. University of California Press, 1982.

DOWNS, A. Up and down with ecology - the "issue attention cycle". The Public Interest, v.28, 38-50, 1972.

DURANT et al. Biotechnology in the public sphere: A European source book. London: Science Museum, 1998.

EKBERG, M. The Parameters of the Risk Society: a review and exploration. Current Sociology v.55(3), 2007.

ENLOE, C. The politics of pollution in a comparative perspective: ecology and power in four nations. David McKay Company, 1975.

ENTMAN, R. Framing: Toward clarification of a fractured paradigm. Journal of Communication, v.43, p. 51-58, 1993.

ESTADÃO DIGITAL. Assine Estadão. Acesso em 05/09/2017. Disponível em $<$ www.assineestadao.com.br $>$.

EYCK, T. WILLIMENT, $M$. The national media and things genetic. Science Communication, 25 (2), 129-152, 2003.

FISHER, K. Locating frames in the discursive universe. Sociological Research Online, 1997.

FISHHOFF, B. The sciences of science communication. Proceedings of the National Academy of Sciences of the United States of America, v.110, 2013.

FOLHA DE S. PAULO. Publicidade Folha. Acesso em 05/09/2017. Disponível em $<$ www.publicidade.folha.com.br>.

GAMSON, A. MODIGLIANI, A. Media discourse and public opinion on nuclear power: A constructionist approach. American Journal of Sociology, 95 (1), 1989.

GAMSON, A. WOLFSFELD, G. Movements and media as interacting systems, The Annals of the American Academy of Political and Social Science v.528, 1993.

GAMSON et al. Media images and social construction of reality. Annual Review of Sociology, 18: 373-93, 1992. 
GASTROW, M. The public understanding of biotechnology in the media: a report for the National Advisory Council on Innovation and the National Biotechnology Advisory Committee. Human Sciences Research Council. July, 2010.

GITLIN, T. The whole world is watching: mass media in the making and unmaking of the new left. Berkeley, Los Angeles: University of California Press, 1980.

GOFFMAN, E. Frame analysis: an essay on the organization of experience. The Maple Press: New York, [1974] 1986.

GORP, B. Where is the frame? Victims and intruders in the Belgian press coverage of the Asylum issue. European Journal of Communication, v.20, 2005.

HANNIGAN, J. Environmental Sociology (2 ${ }^{\text {nd }}$ ed.). Routledge, New York, [1995] 2006.

HERBELÊ, A. Significações dos transgênicos na mídia do Rio Grande do Sul. Universidade do Vale do Rio dos Sinos (Tese de Doutorado), 2005.

IYENGAR, S. Is anyone responsible? How television frames political issues. Illinois: University of Chicago Press, 1991.

KASPERSON, R. The Social Amplification of Risk: progress in developing an integrative framework. In: KRIMSKY \& GOLDING (org), Social Theories of Risk, 1992.

KOENIG, T. On frame and framing: anti-semitism as free speech: a case study. In: Econtro anual do IAMCR, RS: Porto Alegre, Julho, 2004.

LENZI, C. Labeling as precaution: the release of $\mathbf{R R}$ soy and the regulation of transgenics in Brazil. Estudos Sociedade e Agricultura (UFRJ), v. 5, p. 01-35, 2012.

Um território livre para os transgênicos: uma análise do conflito envolvendo a liberação da soja RR no Sul do Brasil. Estudos de Sociologia, v. 18, p. 405-420, 2013.

LIBSTER, L. Media and environment. Polity Press, Cambridge, 2010.

MAESEELE, P. Knowledge, culture and power: biotechnology, public perceptions and the popular press. In: Public Policy and the Mass Media: Influences and Interactions, ECPR Joint Sessions of Workshop Helsinki, 2007.

MATTHES, J. KOHRING, M. The content analysis of media frames: toward improving reliability and validity. Journal of Communication, v. 58, n. 2, p. 258-279, 2008.

MENASCHE, R. Os grãos da discórdia e o trabalho da mídia. Opinião Publica, 2005.

MEDEIROS, F. As páginas de ciência de prestige papers brasileiros na cobertura dos transgênicos em anos de 'hype' (1999-2000). Intercom - Revista Brasileira de Ciências da Comunicação. São Paulo, v.30, n.1, p. 71-93, 2007.

MILES, B. MORSE, S. The role of news media in natural disaster risk and recovery. Ecological Economics, v.63, 2006. 
MILLER, M. RIECHERT, N. Interest group strategies and journalistic norms: news media framing of environmental issues. In: S. Allan, B. Carter (eds), Environmental Risks and the Media (pp. 45-54). London: Routledge, 2000.

NAVARRO, et al. The Bt maize experience in the Philippines: a multi-stakeholder convergence. In: The Media, the Public and Agricultural Biotechnology, 2007.

NISBET, M. LEWENSTEIN, B. Biotechnology and the American media: the policy process and the elite press, 1970 to 1999. Science Communication, 23 (4), 2002.

NISBET, M. HUGE, M. Attention cycles and frames in plant biotechnology debate: managing power and participation through the press/policy connection. Harvard International Journal of Press/Politics, v. 11, n. 2, p. 3-40, 2006.

PAN, P. KOSICKI, M. Framing analysis: An approach to news discourse. Political Communication, 10(1), 55-75, 1993.

PETRARCA, F. A atuação da imprensa e a construção de problemas sociais: os conflitos argumentativos em torno das sementes transgênicos no Rio Grande do Sul. Intexto, 2005.

PRICE et al. Switching trains of thought: the impact of news frames on readers' cognitive responses. Communication Research, 24, 481-506, 1997.

PRIEST, S. Structuring public debate on biotechnology. Science Communication, 1994.

Popular beliefs, media and biotechnology. Communication Uncertainty: Media

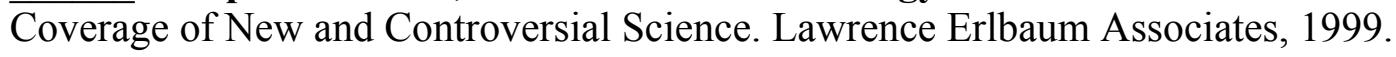

PRIEST, S. EYCK, T. News coverage of biotechnology debates. Society, 40 (6), 2003.

PORTO, M. Enquadramentos da mídia e política. In: A. RUBIM (ed.), Comunicação e política: conceitos e abordagens. Salvador, EDUFBA/Unesp, p. 74-104, 2004.

REESE, S. Prologue - framing public life: A bridging model for media research. In: REESE, S. JR, G. GRANT, A (Orgs.). Framing public life: perspectives on media and our understanding of the social life. NJ: Lawrence Erlbaum Publishers, p. 7-31, 2001.

REINHART, C. Framing the biotechnology debate: a textual analysis of editorials and letters to the editor in the St. Louis Post-Dispatch. Global Media Journal, Spring, 2007.

RENN, O. Risk governance: coping with uncertainty in a complex world. Eathscan, 2008.

RIO+20 - Conferência das Nações Unidas sobre Desenvolvimento Natural. Acesso em 09/08/2017. Disponível em: <rio20.gov.br>.

RIVERS, E. Framing ecologycal risk: mass media frames in the monarch butterfly/transgenic BT Corn case. University of Minnesota (Tese de Doutorado), 2009.

ROTHBERG, D. O conceito de enquadramento e sua contribuição à crítica de mídia. In: R. Christofoletti (Org.), Vitrine e Vidraça: Crítica de Mídia e Qualidade no Jornalismo. LabCom Books, 2010. 
ROTHBERG, D. BERBEL, D. Enquadramentos de transgênicos nos jornais paulista: informação como potencial subsídio à participação pública. História, Ciências, Saúde Manguinhos. Rio de Janeiro, p.455-70, 2010.

RYAN, C. Agriculture, science and public perceptions on biotechnology. Canada, Saskatchewan: Genome Prairie, 2014.

SAPERAS, E. CAMPOS, A. The operationalization of the concept of framing in the Journal of Communication (2009-2013): objects of study, research techniques and theoretical construction. Communication and Society, 28(4), 2015.

SCHEUFELE, D. Framing as a theory of media effects. Journal of Communication, 1999.

SCHEUFELE, D. IYENGAR, S. The state of framing research: A call for new directions. In: KENSI, JAMIESON (Eds.). The Oxford Handbook of Political Communication Theories. New York: Oxford University Press, 2012.

SLOVIC, P. Perception of risk. Science, Cambridge, v.236, p.280-285, 1987.

SOLESBURY, W. The environmental agenda: an illustration of how situations may become political issues and issues may demand responses from government: or how they may not. Public Administration, 379-97, 1976.

SPECTOR, M. KITSUE, J. Social problems: a re-formulation. Social Problems, v.21. CA: Society of Social Problems, 1973.

STALLINGS, R. Media discourse and the social construction of Risk. Social Problems, v.37, n1, 1990.

STOCKING, S. HOLSTEIN, L. Manufacturing doubt: journalists' roles and the construction of ignorance in a scientific controversy. Public Understanding of Science, 2009.

TRAQUINA, N. Teorias do jornalismo, porque as noticias são como são. Insular, 2004.

TUCHMAN, G. Telling stories. Journal of Communications, v.26 93-97, 1976.

. Making news: a study in the construction of reality. NY: Free Press, 1978.

VEYRET, Y. Os riscos: o homem como agressor e vítima do meio ambiente. Editora Contexto, São Paulo, 2007.

WOLF, M. Teorias das comunicações de massa. Martins Fontes, [1987] 2005. 
ANEXO A - EXEMPLO DE CLASSIFICAÇÃO

\section{Elementos Textuais}

-Metáforas: figura de linguagem em que há a designação de um objeto por meio de uma palavra que designa outro objeto que tem com o primeiro uma relação de semelhança;

-Escolha de palavras: relativo ao léxico empregado de modo a realçar um ou outro aspecto; mantêm uma estreita relação com a semântica ao se optar por um termo;

-Argumentos: conjunto de premissas relacionadas tidas como verdadeiras acompanhadas de justificativas lógicas para provar um posicionamento.

\begin{tabular}{|c|c|c|c|c|c|}
\hline Frames & Lead Notícia & Fonte & Data & Conteúdo Considerado para Análise & Elementos Textuais \\
\hline Progresso & "Sementes do futuro" & Folha/UOL & $11 / 10 / 2015$ & $\begin{array}{l}\text { "(...) sua utilização vai devolver à agricultura milhões de } \\
\text { hectares em terra, hoje impróprios para o plantio"; "sementes } \\
\text { que possam aumentar os ganhos por hectare e ser eficientes } \\
\text { no combate a ferrugem" }\end{array}$ & $\begin{array}{l}\text { Presença de menções ao progresso } \\
\text { devido ao uso de biotecnologia. }\end{array}$ \\
\hline Ética & $\begin{array}{l}\text { "Ética e saúde entram no } \\
\text { cardápio do futuro" }\end{array}$ & Folha/UOL & $12 / 10 / 1999$ & $\begin{array}{l}\text { "Também a ética ambiental e social das empresas (...) passará } \\
\text { a ser requisito importante"; "consumidores estarão atentos ao } \\
\text { 'bom comportamento' das empresas de alimentos em relação } \\
\text { ao meio ambiente" }\end{array}$ & $\begin{array}{l}\text { Presença de termos "ética". } \\
\text { Atribuição e valorização moral de } \\
\text { comportamento de empresas. }\end{array}$ \\
\hline Prospecto Econômico & $\begin{array}{l}\text { "Mais milho é mais riqueza } \\
\text { para o Brasil"" }\end{array}$ & $\begin{array}{l}\text { Estadão } \\
\text { Digital }\end{array}$ & $04 / 09 / 2015$ & $\begin{array}{l}\text { " (...) mas terá de investir pesado no aumento do cultivo do } \\
\text { grão, com a biotecnologia sendo cada vez mais uma aliada } \\
\text { imprescindível." }\end{array}$ & $\begin{array}{l}\text { Menção de investimento para } \\
\text { aumento do grão com participação da } \\
\text { biotecnologia. }\end{array}$ \\
\hline C. Pandora & $\begin{array}{l}\text { "Milho transgênico tem } \\
\text { efeito nocivo em ratos" }\end{array}$ & $\begin{array}{l}\text { Estadão } \\
\text { Digital }\end{array}$ & $23 / 05 / 2005$ & $\begin{array}{l}\text { "(...) animais alimentados com o milho geneticamente } \\
\text { modificado apresentaram alterações no sangue e rins menores } \\
\text { (...)"; "o pesquisador (...) classificou os dados como 'muito } \\
\text { preocupantes do ponto de vista médico'". }\end{array}$ & $\begin{array}{l}\text { Presença de afirmações que ligam } \\
\text { relação do consumo de transgênicos } \\
\text { com alterações na saúde. }\end{array}$ \\
\hline Descontrole & $\begin{array}{l}\text { "Ongs pedem moratória de } \\
\text { pesca intensiva e árvores } \\
\text { transgênicas" }\end{array}$ & $\begin{array}{l}\text { Estadão } \\
\text { Digital }\end{array}$ & $28 / 03 / 2006$ & $\begin{array}{l}\text { "Anne Petermann, codiretora da Justiça Global, disse que a } \\
\text { proliferação de árvores transgênicas 'inevitavelmente' vai } \\
\text { alterar as florestas primárias e autóctones". }\end{array}$ & $\begin{array}{l}\text { Atribuição de causa e efeito na } \\
\text { adoção. Presença do advérbio } \\
\text { "inevitavelmente". }\end{array}$ \\
\hline $\begin{array}{l}\text { Responsabilidade } \\
\text { Pública }\end{array}$ & $\begin{array}{l}\text { "Não há perdedores e } \\
\text { ganhadores, diz Dirceu } \\
\text { sobre transgênicos" }\end{array}$ & $\begin{array}{l}\text { Estadão } \\
\text { Digital }\end{array}$ & $30 / 10 / 2003$ & $\begin{array}{l}\text { "Para Dirceu, o texto é adequado porque o País terá condições } \\
\text { legais de pesquisar e plantar variedades transgênicas, sem } \\
\text { contestações posteriores na Justiça"; "Por outro lado, protege, } \\
\text { cumprindo a Constituição Federal (...)". }\end{array}$ & $\begin{array}{l}\text { Notícia relativa ao projeto de lei de } \\
\text { Biossegurança. }\end{array}$ \\
\hline Natureza/Nutrir & $\begin{array}{lc}\text { "Japoneses } & \text { criam rosa } \\
\text { 'azul' } & \text { geneticamente } \\
\text { alterada" } & \end{array}$ & Folha/UOL & $01 / 07 / 2004$ & $\begin{array}{l}\text { "Para adquirir sua cor azulada, a rosa ganhou um gene tirado } \\
\text { de uma tilápia". }\end{array}$ & $\begin{array}{l}\text { Novo variedade de transgênico; } \\
\text { interferência genética. }\end{array}$ \\
\hline Globalização & $\begin{array}{l}\text { "Europa rebate acusação de } \\
\text { Bush sobre fome na África" }\end{array}$ & Folha/UOL & $24 / 06 / 2003$ & $\begin{array}{l}\text { "A União Europeia rejeitou acusações do presidente dos } \\
\text { Estados Unidos de que o veto europeu aos alimentos } \\
\text { transgênicos agravou a fome na África." }\end{array}$ & $\begin{array}{l}\text { Argumento para a disputa global } \\
\text { entre EU e EUA sobre comércio de } \\
\text { alimentos transgênicos. }\end{array}$ \\
\hline
\end{tabular}




\section{ANEXO B - TIPOLOGIA DE FRAME POR AUTOR}

Frame

Autor

Bauer et al. (2001); Durant, Bauer, Gaskell

(1998); Gastrow (2010); Nisbet,

Lewenstein (2002); Reinhart (2007)

Prospecto Econômico

Bauer et al. (2001); Durant, Bauer, Gaskell

(1998); Gastrow (2010); Nisbet,

Lewenstein (2002); Reinhart (2007)

Ética

(1998); Gastrow (2010); Nisbet,

C. de Pandora

Lewenstein (2002); Reinhart (2007)

Bauer et al. (2001); Durant, Bauer, Gaskell

(1998); Gastrow (2010); Nisbet,

Lewenstein (2002); Reinhart (2007)

Descontrole Bauer et al. (2001); Durant, Bauer, Gaskell

(1998); Gastrow (2010); Nisbet,

Lewenstein (2002); Reinhart (2007)

Natureza/Nutrir

Bauer et al. (2001); Durant, Bauer, Gaskell

(1998); Gastrow (2010); Nisbet,

Lewenstein (2002); Reinhart (2007)

Responsabilidade Pública

Bauer et al. (2001); Durant, Bauer, Gaskell

(1998); Gastrow (2010); Nisbet,

Lewenstein (2002); Reinhart (2007)

Globalização

Bauer et al. (2001); Durant, Bauer, Gaskell

(1998); Gastrow (2010); Nisbet,

Lewenstein (2002); Reinhart (2007)

\section{Definição Utilizada pelo Autor}

Celebração da tecnologia nova e disruptiva; direção da história; conflito entre progressistas/conservadores reacionários.

Potencial econômico; prospectos para investimentos e lucros; argumentos de pesquisa e desenvolvimento.

Chamada para os princípios éticos; limites, fronteiras e distinções de riscos aceitáveis e inevitáveis em discussão dos riscos conhecidos; dilemas morais.

Chamada por limitações frente ao risco desconhecido; abertura dos portões do perigo; riscos desconhecidos como ameaças antecipadas; precaução com catástrofes.

Fatalismo pós inovação; uma vez adotada a tecnologia, o preço a ser pago no futuro; não há mais controles depois do evento.

Ambiente versus determinação genética; questões de herança.

Chamada para o controle público, participação e envolvimento; mecanismos de regulação; interesses privados versus interesse público.

Chamada para a perspectiva global; competitividade nacional dentro de um contexto de economia global. 
ANEXO B - CONTINUAÇÃO

\begin{tabular}{lll}
\multicolumn{1}{c}{ Frame } & \multicolumn{1}{c}{ Autor } & \multicolumn{1}{c}{ Definição Utilizada pelo Autor } \\
\hline $\begin{array}{l}\text { Progresso } \\
\text { Prospecto Econômico }\end{array}$ & Maeseele (2007) & $\begin{array}{l}\text { O ponto de partida da celebração do progresso científico, novo desenvolvimento e avanço. } \\
\text { Ética }\end{array}$ \\
C. de Pandora & $\begin{array}{l}\text { Maeseele (2007) } \\
\text { consequências financeiras. } \\
\text { Biotecnologia preocupada sob o ponto de vista ético, contrabalanceando prós e contras, fazendo-se julgamentos de valor. }\end{array}$ \\
Mescontrole & Maeseele (2007) & $\begin{array}{l}\text { A específica aplicação da biotecnologia é tomada como ameaça potencial séria se implantada inicialmente ou continuadamente sem } \\
\text { as consequências estarem claras, é aconselhado nesses casos a não continuar ou não proceder primeiramente. }\end{array}$ \\
Natureza/Nurtir & $\begin{array}{l}\text { Uma aplicação existente é julgada prejudicial e as consequência já são irreversíveis, o argumento sendo que a biotecnologia pode } \\
\text { ser descontinuada como para evitar piores consequências e empenho em exercícios de limitação. }\end{array}$ \\
Resp. Pública & Maeseele (2007) & $\begin{array}{l}\text { Debate sobre a hereditariedade e componentes genéticos nos organismos, mais especificamente a questão do que é pré-determinado } \\
\text { por fatores hereditários no momento da concepção e o que é condicionado por fatores ambientais. }\end{array}$ \\
Globalização & Maeseele (2007) & $\begin{array}{l}\text { Demanda por transparência com respeito a procedimentos, regulações e mais envolvimento e participação do público. } \\
\text { Chamada para uma perspectiva global da biotecnologia, competitividade em um contexto de economia global. }\end{array}$ \\
\hline
\end{tabular}

\begin{tabular}{|c|c|c|}
\hline Frame & Autor & Definição Utilizada pelo Autor \\
\hline Progresso & Dahinden (2002) & $\begin{array}{l}\text { Ciência é informar o público sobre questões sem nenhum impacto em decisões práticas; ciência como consultora para decisões } \\
\text { individuais e sociais que não são muito contestadas. }\end{array}$ \\
\hline Prospecto Econômico & Dahinden (2002) & Perspectivas econômicas e científicas da tecnologia. \\
\hline Ética & Dahinden (2002) & Mensagens morais, princípios éticos, prescrições sociais. \\
\hline C. de Pandora & Dahinden (2002) & $\begin{array}{l}\text { Chamada para contenção em face de riscos desconhecidos, "abertura dos portões do perigo", precauções gerais e precauções de } \\
\text { catástrofes. }\end{array}$ \\
\hline Descontrole & Dahinden (2002) & Não há definição. \\
\hline Natureza/Nutrir & Dahinden (2002) & Sem poder, fatalismo após adotar a nova tecnologia. \\
\hline Responsabilidade Pública & Dahinden (2002) & Governos e outros corpo públicos tem a habilidade de endereçar o problema. \\
\hline Globalização & Dahinden (2002) & $\begin{array}{l}\text { Chamada para uma perspectiva global, competitividade nacional em um contexto de economia global, ou o contrário: isolamento } \\
\text { esplêndido. }\end{array}$ \\
\hline
\end{tabular}


ANEXO B - CONTINUAÇÃO

Frame

Progresso

Prospecto Econômico

Ética

C. de Pandora

Descontrole

Natureza/Nutrir

Responsabilidade Pública

Globalização
Autor

\section{Definição Utilizada pelo Autor}

Bonfadelli et al. (2007) Descreve biotecnologia em termos positivos e a celebra como um novo desenvolvimento com o potencial para ciência e saúde uma tecnologia que serve a sociedade.

Bonfadelli et al. (2007) Sem dados

Bonfadelli et al. (2007) Avaliação das questões com fundo de valores morais explícito.

Bonfadelli et al. (2007) Avisos antes da catástrofe, chamada para restrições contra riscos desconhecidos.

Bonfadelli et al. (2007) Sem dados

Bonfadelli et al. (2007) Sem dados

Bonfadelli et al. (2007) Chamada para o controle público, envolvimento do público e mecanismos de controle.

Bonfadelli et al. (2007) Sem dados 
ANEXO C - ESTATÍSTICAS GERAIS

\begin{tabular}{|c|c|c|c|c|c|c|c|c|c|c|c|c|c|c|c|c|c|c|c|c|}
\hline & 1998 & 1999 & 2000 & 2001 & 2002 & 2003 & 2004 & 2005 & 2006 & 2007 & 2008 & 2009 & 2010 & 2011 & 2012 & 2013 & 2014 & 2015 & Total & $\%$ \\
\hline Folha/UOL & 8 & 29 & 67 & 82 & 31 & 115 & 127 & 31 & 20 & 16 & 18 & 22 & 11 & 10 & 1 & 1 & 7 & 8 & 604 & $57 \%$ \\
\hline Estadão Digital & 0 & 0 & 6 & 50 & 80 & 243 & 215 & 14 & 24 & 19 & 25 & 15 & 29 & 25 & 16 & 9 & 11 & 11 & 792 & $43 \%$ \\
\hline Total & 8 & 29 & 73 & 132 & 111 & 358 & 342 & 45 & 44 & 35 & 43 & 37 & 40 & 35 & 17 & 10 & 18 & 19 & 1396 & $100 \%$ \\
\hline
\end{tabular}

\begin{tabular}{ccccccccc} 
Seção & Quant. & $\%$ & \multicolumn{2}{c}{ Estadão Digital } & Folha/UOL \\
\hline Ciência & 455 & $33 \%$ & R. pública & $56 \%$ & 444 & R. pública & $59 \%$ & 358 \\
Mercado & 255 & $18 \%$ & Globalização & $14 \%$ & 110 & Globalização & $10 \%$ & 60 \\
Economia & 212 & $15 \%$ & C. de Pandora & $13 \%$ & 99 & C. de Pandora & $11 \%$ & 69 \\
Política & 190 & $14 \%$ & Progresso & $10 \%$ & 76 & Progresso & $12 \%$ & 74 \\
Geral & 56 & $4 \%$ & p. econômico & $6 \%$ & 45 & P. econômico & $5 \%$ & 33 \\
Opinião & 43 & $3 \%$ & Ética & $2 \%$ & 14 & Ética & $1 \%$ & 7 \\
Internacional & 24 & $2 \%$ & Descontrole & $1 \%$ & 4 & Natureza & $0 \%$ & 3 \\
Poder & 18 & $1 \%$ & & & & & & \\
Outras & 143 & $10 \%$ & & & & & & \\
Total & 1396 & $100 \%$ & & $100 \%$ & 792 & & & \\
\hline
\end{tabular}

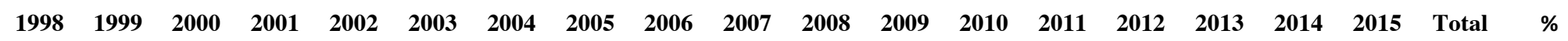

\begin{tabular}{|c|c|c|c|c|c|c|c|c|c|c|c|c|c|c|c|c|c|c|c|c|}
\hline Caixa de Pandora & 1 & 9 & 4 & 17 & 12 & 40 & 26 & 15 & 7 & 6 & 6 & 6 & 7 & 5 & 1 & 1 & 0 & 5 & 168 & $12,0 \%$ \\
\hline Descontrole & 0 & 0 & 0 & 0 & 0 & 0 & 0 & 0 & 1 & 0 & 2 & 0 & 0 & 1 & 0 & 0 & 0 & 0 & 4 & $0,3 \%$ \\
\hline Ética & 0 & 1 & 1 & 0 & 3 & 6 & 4 & 0 & 2 & 0 & 1 & 0 & 1 & 1 & 0 & 1 & 0 & 0 & 21 & $1,5 \%$ \\
\hline Globalização & 1 & 2 & 5 & 27 & 37 & 47 & 25 & 4 & 4 & 1 & 0 & 3 & 7 & 2 & 0 & 3 & 2 & 0 & 170 & $12,2 \%$ \\
\hline Natureza & 0 & 0 & 1 & 0 & 0 & 1 & 0 & 1 & 0 & 0 & 0 & 0 & 0 & 0 & 0 & 0 & 0 & 0 & 3 & $0,2 \%$ \\
\hline P. econômico & 0 & 0 & 1 & 2 & 4 & 22 & 21 & 0 & 1 & 6 & 4 & 2 & 7 & 3 & 2 & 2 & 1 & 0 & 78 & $5,6 \%$ \\
\hline Progresso & 1 & 3 & 9 & 14 & 8 & 19 & 33 & 6 & 6 & 5 & 8 & 7 & 8 & 6 & 6 & 1 & 9 & 1 & 150 & $10,7 \%$ \\
\hline R. pública & 5 & 14 & 52 & 72 & 47 & 223 & 233 & 19 & 23 & 17 & 22 & 19 & 10 & 17 & 8 & 2 & 6 & 13 & 802 & $57,4 \%$ \\
\hline Total & 8 & 29 & 73 & 132 & 111 & 358 & 342 & 45 & 44 & 35 & 43 & 37 & 40 & 35 & 17 & 10 & 18 & 19 & 1396 & $100 \%$ \\
\hline
\end{tabular}




\section{ANEXO C - DISTRIBUIÇÃO DAS NOTÍCIAS}

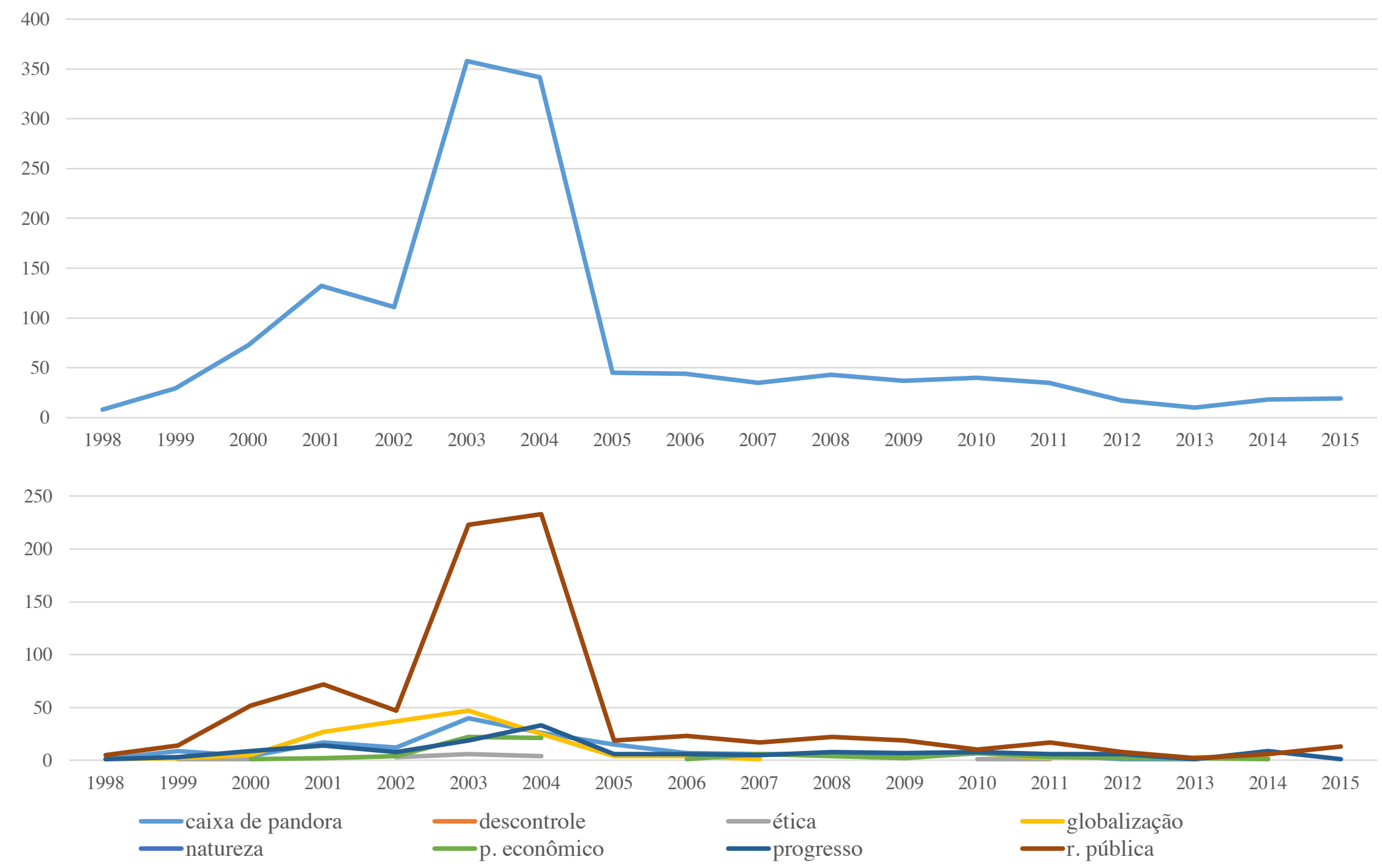


ANEXO C - DISTRIBUIÇÃO DAS NOTÍCIAS

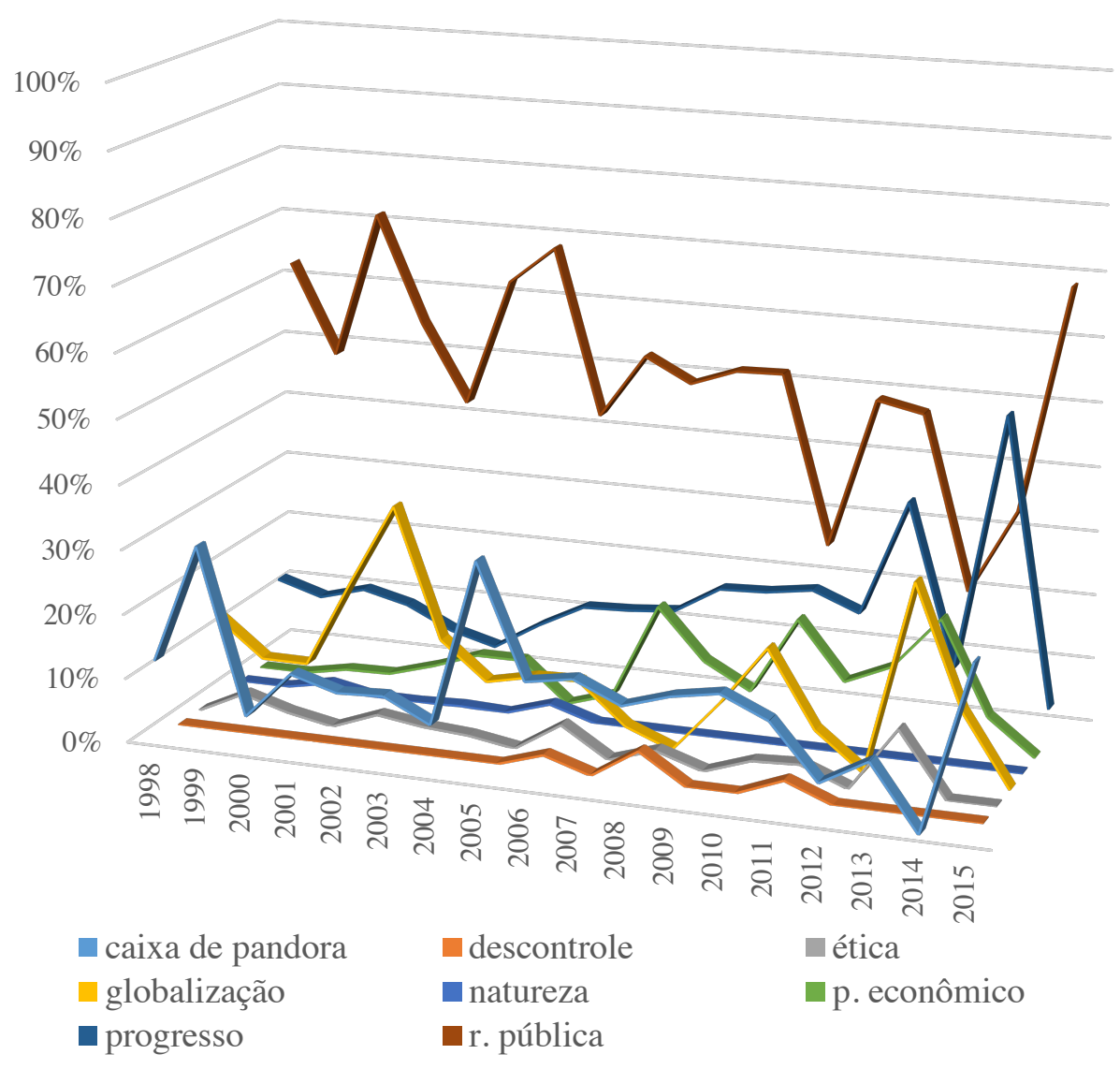

400

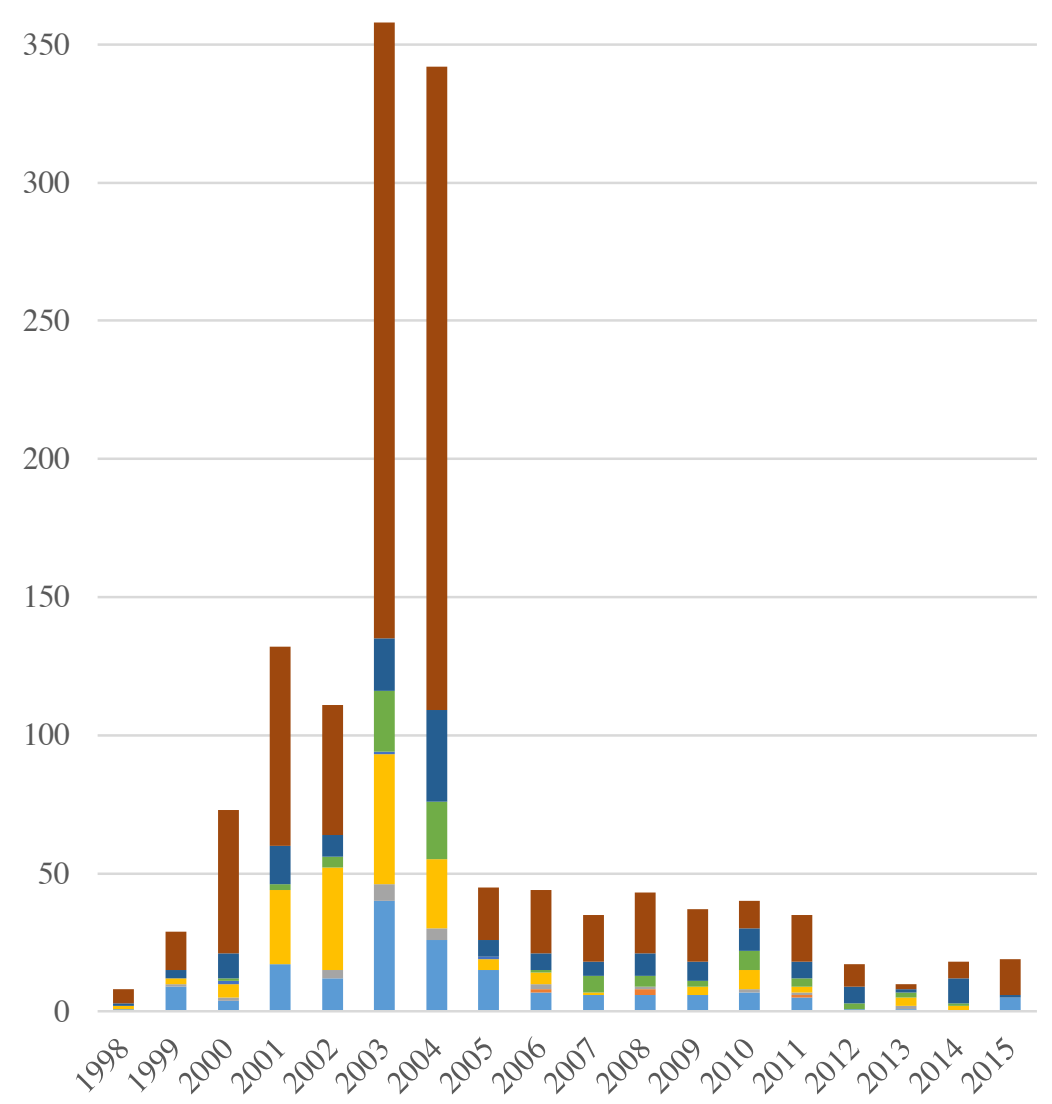




\section{ANEXO C - DISTRIBUIÇÃO DOS TEMAS}

Frames Temas

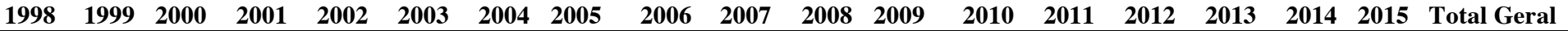

Resp. Pública regulação

Resp. Pública conflito

Resp. Pública fiscalização

Resp. Pública rotulagem

C. de Pandora risco ambiental

Resp. Pública protesto

Progresso produtividade

Resp. Pública princípio de precaução

Progresso desenvolvimento

Progresso pesquisa infos produtos com

Resp. Pública transgênicos

Progresso benefícios saúde

Globalização cooperação internacional

C. de Pandora risco econômico

Resp. Pública Oport. de desenvolvimento

C. de Pandora risco saúde humana

Resp. Pública avanço dos transgênicos

Outros

$\begin{array}{llllllllllll}3 & 4 & 25 & 14 & 27 & 126 & 151 & 5 & 12 & 9 & 9 & 5\end{array}$

\begin{tabular}{|c|c|c|c|c|c|c|c|c|c|c|c|c|c|c|c|c|c|c|}
\hline 3 & 4 & 25 & 14 & 27 & 126 & 151 & 5 & 12 & 9 & 9 & 5 & 4 & 8 & 2 & 1 & 1 & 2 & 408 \\
\hline \multirow[t]{3}{*}{2} & 4 & 6 & 12 & 13 & 54 & 32 & 8 & 5 & 1 & 3 & 5 & 5 & & 1 & 2 & 2 & 1 & 156 \\
\hline & 2 & 6 & 3 & 4 & 25 & 24 & 2 & 4 & 1 & 1 & 3 & 1 & 1 & & & & & 77 \\
\hline & 3 & 6 & 9 & 2 & 10 & 18 & 2 & 3 & 2 & 5 & 1 & 1 & 2 & 1 & & & 7 & 72 \\
\hline \multirow[t]{13}{*}{1} & 6 & 2 & 5 & 2 & 9 & 12 & 10 & 4 & 2 & 1 & 3 & 3 & 2 & 1 & & & 4 & 67 \\
\hline & 1 & 3 & 26 & 5 & 12 & 3 & 1 & 1 & & 1 & 1 & & 4 & & & & 2 & 60 \\
\hline & 1 & 2 & 7 & 4 & 6 & 9 & 1 & 1 & 1 & 4 & 3 & 6 & 4 & 2 & 1 & 3 & 1 & 56 \\
\hline & & 1 & 2 & 7 & 19 & 10 & & 1 & 2 & & 1 & & 2 & & & & & 45 \\
\hline & & & & 1 & 12 & 12 & & & 4 & 2 & 2 & 5 & 2 & 1 & 1 & & & 42 \\
\hline & & 1 & 6 & 3 & 11 & 9 & 2 & & 2 & 1 & & 3 & & & & 2 & 1 & 41 \\
\hline & & 7 & 14 & 9 & 5 & & 1 & & & & & & & & & & & 36 \\
\hline & 1 & 3 & 3 & 1 & 4 & 3 & 1 & 2 & 2 & 4 & 1 & 1 & 2 & 1 & & 1 & & 30 \\
\hline & & & & 8 & 5 & 4 & 1 & 1 & 1 & & 1 & 1 & & & 1 & 1 & & 24 \\
\hline & & 1 & 4 & & 7 & 2 & 2 & 2 & 2 & 1 & 1 & & & & & & & 22 \\
\hline & & & & 2 & 7 & 8 & & 1 & & & & 1 & & & & 1 & & 20 \\
\hline & 3 & & 4 & 2 & 2 & 1 & 2 & & & 3 & 1 & 2 & & & & & & 20 \\
\hline & & & 2 & 2 & 4 & 1 & & 1 & & 2 & 2 & 2 & 1 & 1 & & 1 & & 19 \\
\hline 2 & 4 & 10 & 21 & 19 & 40 & 43 & 7 & 6 & 6 & 6 & 7 & 5 & 7 & 7 & 4 & 6 & 1 & 201 \\
\hline
\end{tabular}

$\begin{array}{llllll}8 & 2 & 1 & 1 & 2 & 408\end{array}$

*Os temas regulação e conflito, enquadrados em "responsabilidade pública" representam cerca de $40 \%$ de todas as notícias (564 de um total de 1.396). Se considerarmos somente o biênio 2003/04, os mesmos temas compõem cerca de $26 \%$ de todas as notícias (363 de 1.396$)$.

**Os quatro temas mais frequentes (regulação, conflito, fiscalização e rotulagem) são enquadrados no frame "responsabilidade pública". 


\section{ANEXO C - FRAMES POR ONDA}

\begin{tabular}{|c|c|c|c|}
\hline Frames de notícia & Introdução Comercial (1998/2002) & Os anos da controvérsia $(2003 / 04)$ & Polêmicas para além da regulação $(2005 / 15)$ \\
\hline Caixa de pandora & $43 \quad 12 \%$ & $669 \%$ & $59 \quad 17 \%$ \\
\hline Ética & $5 \quad 1 \%$ & $101 \%$ & $62 \%$ \\
\hline Globalização & $72 \quad 20 \%$ & $72 \quad 10 \%$ & $268 \%$ \\
\hline Natureza & $10 \%$ & $10 \%$ & $10 \%$ \\
\hline P. econômico & $72 \%$ & $43 \quad 6 \%$ & $28 \quad 8 \%$ \\
\hline Progresso & $35 \quad 10 \%$ & $527 \%$ & $6318 \%$ \\
\hline R. pública & $19054 \%$ & $456 \quad 65 \%$ & $15645 \%$ \\
\hline Descontrole & $0 \quad 0 \%$ & $0 \quad 0 \%$ & $41 \%$ \\
\hline Total Geral & 353 & 700 & 343 \\
\hline
\end{tabular}

Introdução Comercial

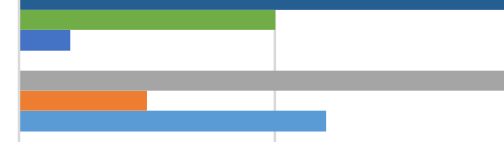

Os anos da controvérsia

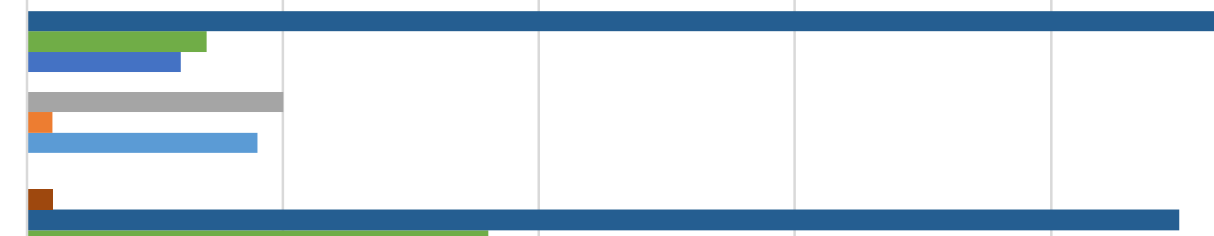

Polêmicas para além da regulação
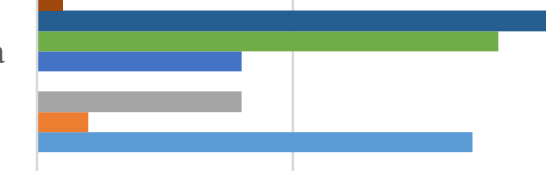

- Descontrole

R. pública

$10 \%$

$20 \%$
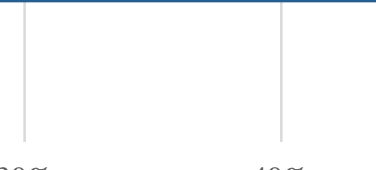

Natureza 
ANEXO D - AMOSTRAGEM

\begin{tabular}{rrrrr} 
& \multicolumn{3}{c}{ FSP } & \\
\cline { 2 - 4 } 1998 a 2002 & UNIVERSO & \multicolumn{3}{c}{ AMOSTRA } \\
$2003 / 04$ & 1392 & $23 \%$ & 217 & $16 \%$ \\
2005 & 1331 & $22 \%$ & 242 & $17 \%$ \\
$2006 / 11$ & 228 & $4 \%$ & 31 & $2 \%$ \\
$2012 / 14$ & 627 & $10 \%$ & 97 & $7 \%$ \\
2015 & 180 & $3 \%$ & 9 & $1 \%$ \\
& 71 & $1 \%$ & 8 & $1 \%$ \\
& & ESPD & & \\
1998 a 2002 & 267 & $4 \%$ & 136 & $10 \%$ \\
$2003 / 04$ & 710 & $12 \%$ & 458 & $33 \%$ \\
2005 & 38 & $1 \%$ & 14 & $1 \%$ \\
$2006 / 11$ & 862 & $14 \%$ & 137 & $10 \%$ \\
$2012 / 14$ & 350 & $6 \%$ & 36 & $3 \%$ \\
2015 & 87 & $1 \%$ & 11 & $1 \%$
\end{tabular}

TOTAL

\begin{tabular}{rrrrr} 
& UNIVERSO & \multicolumn{3}{c}{ AMOSTRA } \\
1998 a 2002 & 1659 & $27 \%$ & 353 & $25 \%$ \\
$2003 / 04$ & 2041 & $33 \%$ & 700 & $50 \%$ \\
2005 & 266 & $4 \%$ & 45 & $3 \%$ \\
$2006 / 11$ & 1489 & $24 \%$ & 234 & $17 \%$ \\
$2012 / 14$ & 530 & $9 \%$ & 45 & $3 \%$ \\
2015 & 158 & $3 \%$ & 19 & $1 \%$ \\
& 6143 & & 1396 &
\end{tabular}




\section{ANEXO D - AMOSTRAGEM}

A figura abaixo apresenta o número total de notícias recuperadas dos portais e a amostra selecionada. Há um comportamento semelhante entre os dados brutos recuperados (notícias sem os crivos de seleção) e os dados selecionados em nossa amostra: um noticiamento que cresce até 2003 e 2004 e que depois perde força.

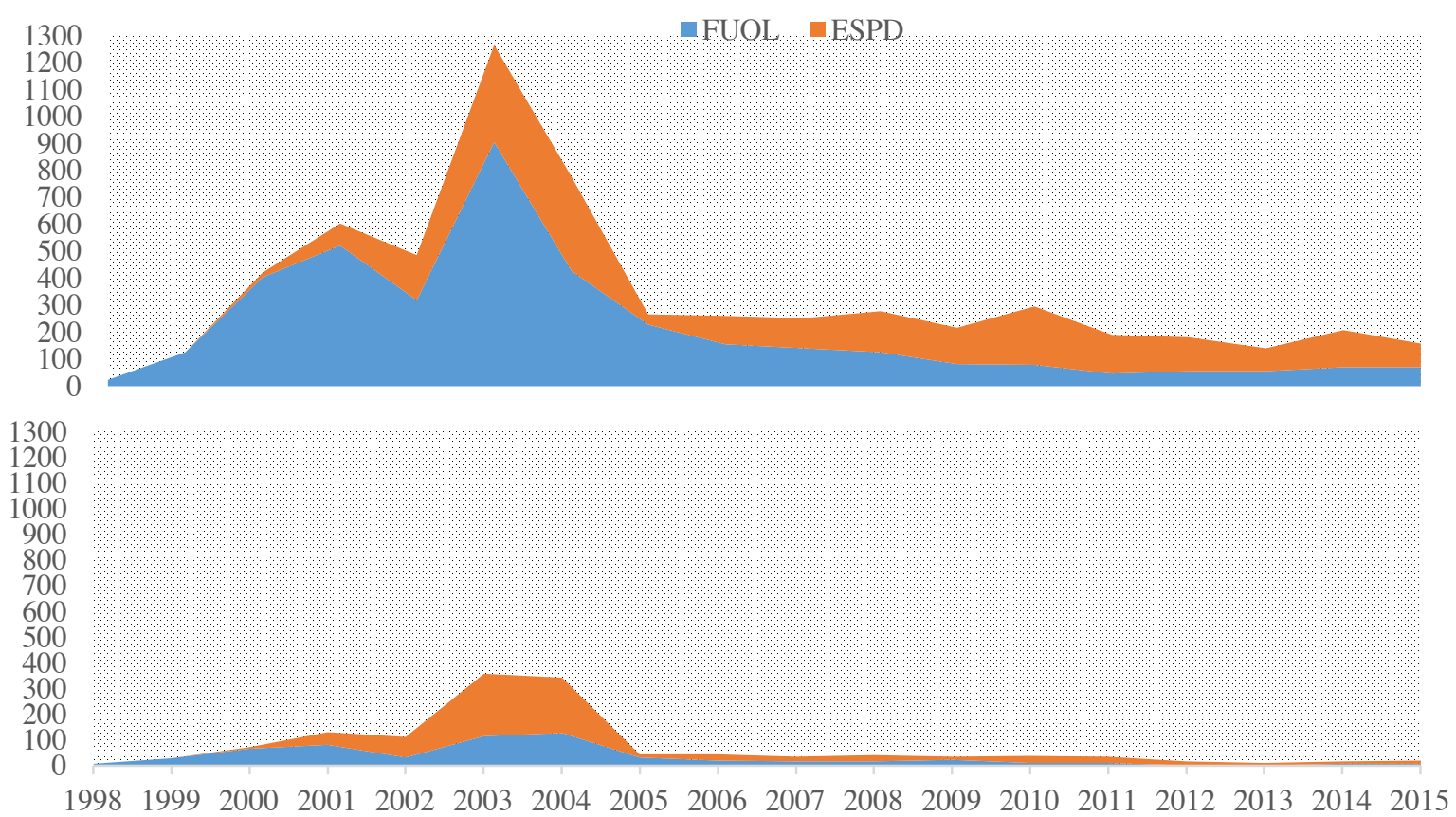

Fonte: buscas realizadas nos motores internos dos portais "Estadão Digital" e "Folha de S. Paulo" em 02/02/2016. O primeiro histograma apresenta o número total de notícias recuperadas por "transgênicos". Já o segundo, apresenta nossa amostra qualificada segundo os critérios adotados.

Com base nos critérios para seleção de notícias, seguimos os seguintes passos:

(i) os critérios mais empregados foram descartar as notícias duplicadas, links em final de artigos e as reportagens relacionadas à biotecnologia vermelha mediante uma primeira leitura dinâmica. Selecionamos a quantidade de 2.458 artigos após nove meses de coleta, iniciada em abril de 2016 e finalizada em janeiro de 2017;

(ii) no período de janeiro e abril de 2017, houve uma reclassificação dos frames de notícia nos artigos selecionados, com base nos critérios que avaliavam se os artigos eram substancialmente relacionados com nosso objeto de estudo, chegando-se à quantidade de 2.219 notícias;

(iii) por fim, houve mais uma dupla-checagem com bases nos critérios que avaliavam se os artigos eram substancialmente relacionados com a pauta dos transgênicos, entre abril e junho de 2017. Chegamos ao valor de 1.396 artigos. A tabulação completa dos dados pode ser visualizada e baixada no endereço eletrônico: $<$ bit.ly/2keCi6c $>$. 